\title{
OBSERVATIONS ON FAULTS AND ASSOCIATED \\ PERMEABILITY STRUCTURES IN HYDROGEOLOGIC UNITS AT THE NEVADA TEST SITE
}

March 2009

Prepared for:

U.S. Department of Energy

National Nuclear Security Administration

Nevada Site Office

Prepared by:

Lance B. Prothro, Sigmund L. Drellack, Jr., Dawn N. Haugstad, Heather E. Huckins-Gang, and Margaret J. Townsend

Underground Test Area and Boreholes Programs and Operations

Environmental Restoration

National Security Technologies, LLC

Las Vegas, Nevada 


\section{DISCLAIMER STATEMENT}

Reference herein to any specific commercial product, process, or service by trade name, trademark, manufacturer, or otherwise, does not necessarily constitute or imply its endorsement, recommendation, or favoring by the U.S. Government or any agency thereof or its contractors or subcontractors.

\section{AVAILABILITY STATEMENT}

Available to the public, in paper from-

U.S. Department of Commerce

National Technical Information Service

5285 Port Royal Road

Springfield, VA 22161-0002

Telephone: 800.553.6847

Fax: 703.605.6900

E-mail: orders@ntis.gov

Online ordering: http://www.ntis.gov/ordering.htm

Available electronically at http://www.osti.gov/bridge

Available for a processing fee to U.S. Department of Energy and its contractors, in paper, from-

\section{U.S. Department of Energy}

Office of Scientific and Technical Information

P.O. Box 62

Oak Ridge, TN, 37831-0062

Telephone: 865.576.8401

Fax: 865.576.5728

E-mail: reports@adonis.osti.gov 


\title{
Observations on Faults and Associated Permeability Structures in Hydrogeologic Units at the Nevada Test Site
}

\author{
Prepared for: \\ U.S. Department of Energy \\ National Nuclear Security Administration \\ Nevada Site Office \\ Las Vegas, Nevada
}

\author{
Prepared by: \\ Lance B. Prothro, Sigmund L. Drellack, Jr., Dawn N. Haugstad, \\ Heather E. Huckins-Gang, and Margaret J. Townsend \\ Underground Test Area and Boreholes Programs and Operations \\ National Security Technologies, LLC \\ Las Vegas, Nevada
}

March 2009 
This page intentionally left blank. 


\section{ABSTRACT}

Observational data on Nevada Test Site (NTS) faults were gathered from a variety of sources, including surface and tunnel exposures, core samples, geophysical logs, and down-hole cameras. These data show that NTS fault characteristics and fault zone permeability structures are similar to those of faults studied in other regions. Faults at the NTS form complex and heterogeneous fault zones with flow properties that vary in both space and time. Flow property variability within fault zones can be broken down into four major components that allow for the development of a simplified, first approximation model of NTS fault zones. This conceptual model can be used as a general guide during development and evaluation of groundwater flow and contaminate transport models at the NTS. 
This page intentionally left blank. 


\section{Table of Contents}

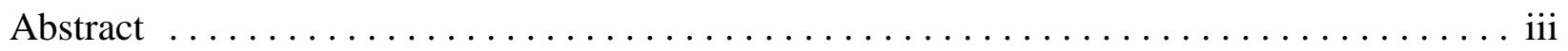

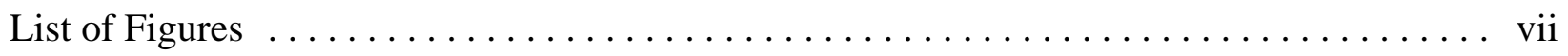

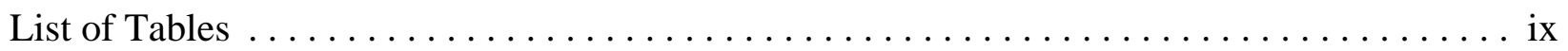

List of Acronyms and Abbreviations $\ldots \ldots \ldots \ldots \ldots \ldots \ldots \ldots \ldots \ldots \ldots \ldots \ldots \ldots \ldots \ldots$

1.0 Introduction $\ldots \ldots \ldots \ldots \ldots \ldots \ldots \ldots \ldots \ldots \ldots \ldots \ldots \ldots \ldots \ldots \ldots \ldots . \ldots \ldots \ldots$

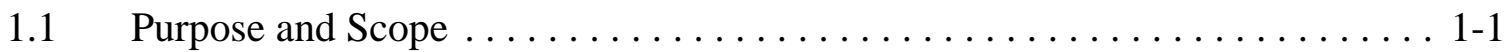

1.2 Overview of Faults and Associated Permeability Structures . . . . . . . . . 1-2

1.2.1 Faults at the NTS ..................... 1-5

1.2.2 Fault Zone Architecture . . . . . . . . . . . . . . . . 1-6

1.2.2.1 Fault Core .................. 1-6

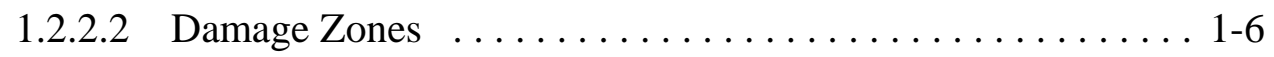

1.2.2.3 Protolith ....................... . . . .

1.3 Factors Controlling Fault-Related Fluid-Flow Properties . . . . . . . . . . 1-8

1.4 Hydrogeologic Units at the NTS . . . . . . . . . . . . . . 1-9

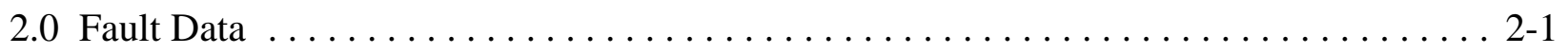

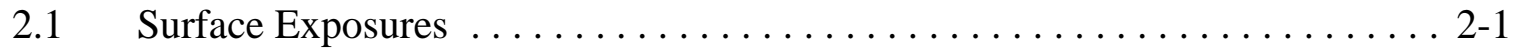

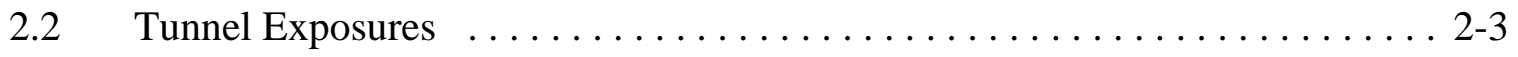

2.2.1 Rainier Mesa Tunnels . . . . . . . . . . . . . . . . 2-3

2.2 .2 U1a Complex . . . . . . . . . . . . . . . . . . . . . 2-5

2.3 Core Samples ........................

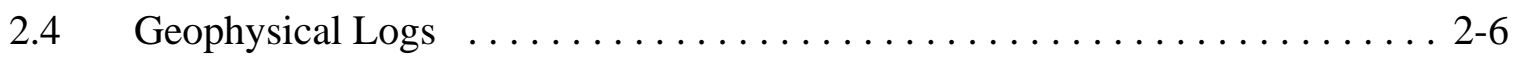

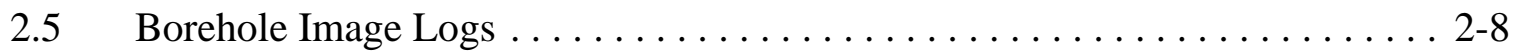

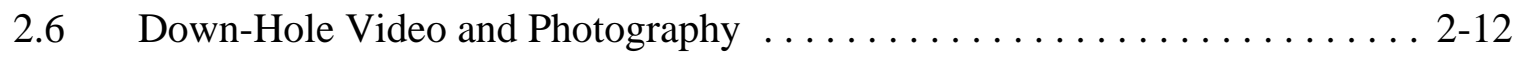

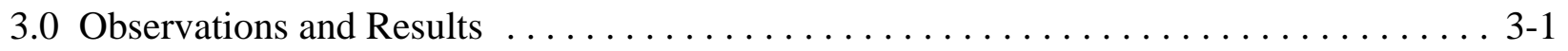

3.1 General Observations . . . . . . . . . . . . . . . . . .

3.1 .1 Fault Core Zones $\ldots \ldots \ldots \ldots \ldots \ldots \ldots \ldots \ldots \ldots \ldots \ldots \ldots \ldots \ldots \ldots \ldots$

3.1 .2 Damage Zones . . . . . . . . . . . . . . . . . . . 3-6

3.2 Fault Characteristics in Hydrogeologic Units . . . . . . . . . . . . . 3-7

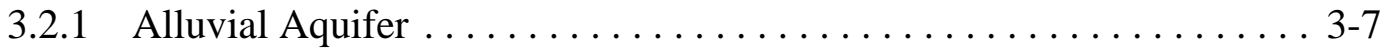

3.2 .2 Vitric-Tuff Aquifer $\ldots \ldots \ldots \ldots \ldots \ldots \ldots \ldots \ldots \ldots . \ldots \ldots$

3.2 .3 Welded-Tuff Aquifer . . . . . . . . . . . . . . . . . . 3-9

3.2.4 Tuff Confining Unit . . . . . . . . . . . . . . . . . 3-10

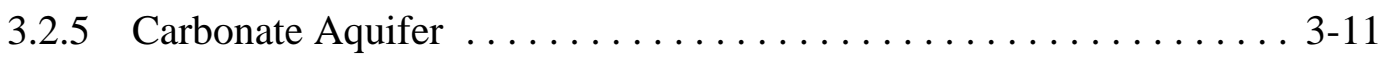

3.2 .6 Other HGUs . . . . . . . . . . . . . . . . . . . 3-11 


\section{Table of Contents, continued}

4.0 Implications for Groundwater Flow Modeling $\ldots \ldots \ldots \ldots \ldots \ldots \ldots \ldots \ldots$. . . . . . . .

5.0 Summary of Conclusions $\ldots \ldots \ldots \ldots \ldots \ldots \ldots \ldots \ldots \ldots \ldots \ldots \ldots \ldots \ldots \ldots \ldots$

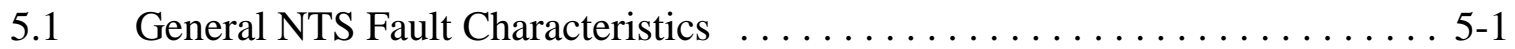

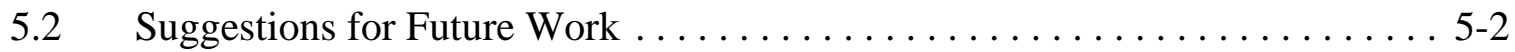

6.0 References . . . . . . . . . . . . . . . . . . . . . . . . . . . . 6-1

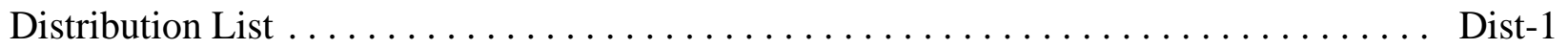

Appendix A Fault Descriptions and Photographs 


\section{List of Figures}

Number

Title

Page

1-1 Schematic Diagrams Illustrating Fault Block Relationships ................ 1-4

1-2 Cross-Sectional View Across a Fault Zone Showing Architectural Components

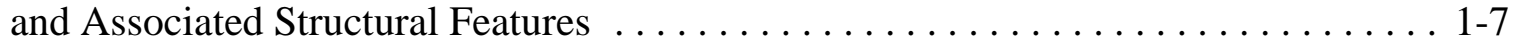

2-1 Generalized Geologic Map Showing Locations of Fault Stations with

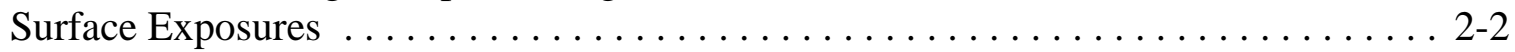

2-2 Generalized Geologic Map Showing Locations of Fault Stations Associated with Tunnels, Down-Hole Cameras, and Vertical Core Holes ................ 2-4

2-3 Portions of the Caliper and Resistivity Logs for Drill Hole UE-1q Showing Log Signatures Across the Topgallant Fault in Yucca Flat ............... 2-9

2-4 A Portion of the Borehole Image Log from UGTA Well ER-16-1 Showing a

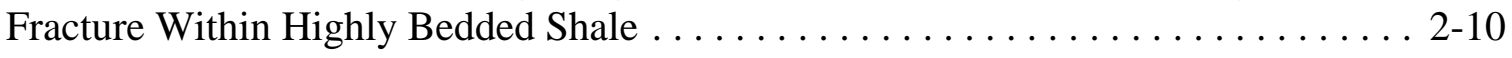

2-5 A Portion of the Borehole Image Log and Dip Vector Plot for UGTA Well ER-12-2 Showing Drag Folding in the Hanging Wall of a Thrust Fault

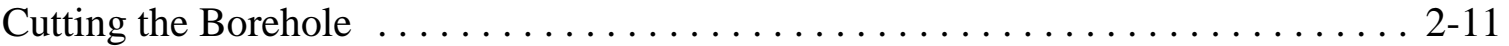

4-1 Secondary Calcite in Core Samples from the Hanging Wall of the CP Thrust Fault in UGTA Well ER-6-2 . . . . . . . . . . . . . . . . . . . . . . . . . . . . . . 4-4

4-2 Fault on the Timber Mountain Resurgent Dome within the Timber Mountain Caldera Complex, Showing Secondary Silica Mineralization within Fault Zone .... . 4-5

\begin{tabular}{|c|c|}
\hline A-1 & Fault Station FF-3 \\
\hline A-2 & Fault Station FP-2 \\
\hline A-3 & Plutonium Valley Fault \\
\hline A-4 & Location Index for Photographs of the Plutonium Valley Fault \\
\hline A-5 & Fault Station FP-4 (hanging wall) \\
\hline \begin{tabular}{|c|}
$\mathrm{A}-6$ \\
\end{tabular} & Fault Station FP-4 (footwall) \\
\hline A-7 & Fault Station FP-5 \\
\hline $\mathrm{A}-8$ & Fault Station FP-15 (hanging wall) \\
\hline A-9 & Fault Station FP-15 (footwall) \\
\hline$\overline{\mathrm{A}-10}$ & Faults in the Footwall of the Plutonium Valley Fault \\
\hline A-11 & Fault Station PR-13 \\
\hline$\overline{\mathrm{A}-12}$ & Fault Station PR-14 (fault core) \\
\hline A-13 & Fault Station PR-14 (footwall) \\
\hline A-14 & Fault Station PR-21 \\
\hline $\mathrm{A}-15$ & Fault Station PR-31 \\
\hline
\end{tabular}




\section{List of Figures (continued)}

\begin{tabular}{|c|c|}
\hline $\mathrm{A}-16$ & Fault Station PR-33 \\
\hline A-17 & Fault Station PR-33 (detail) \\
\hline A-18 & Fault Station PR-65 (part one) \\
\hline A-19 & Fault Station PR-65 (part two) \\
\hline A-20 & Fault Station TP-100 \\
\hline A-21 & Fault Station TP-101 \\
\hline $\mathrm{A}-22$ & Fault Station TP-102 \\
\hline A-23 & Fault Station TS-4 \\
\hline A-24 & Fault Station U1a \\
\hline A-25 & Fault Station N-GSD X-Cut \\
\hline A-26 & Fault Station N-10-A \\
\hline$\overline{\mathrm{A}-27}$ & Fault Station N-21BP-2 \\
\hline A-28 & Fault Station N-17BP \\
\hline A-29 & Fault Station N-21LOS-1 \\
\hline A-30 & Fault Station N-21LOS-2 \\
\hline A-31 & Fault Station N-22BP \\
\hline A-32 & Fault Station N-24BP \\
\hline A-33 & Fault Station T-002 \\
\hline A-34 & Fault Station T-003 \\
\hline A-35 & Fault Station UE-6d\#2-1016.7 \\
\hline A-36 & Fault Station UE-7f-2321 \\
\hline A-37 & Fault Station U12T.03UG1-2628 \\
\hline A-38 & Fault Station U12T.03UG1-2628 (detail) \\
\hline A-39 & Fault Station U12T.03UG1-2735 \\
\hline A-40 & Fault Station U-3mL-2940 \\
\hline A-41 & Fault Station U-7by-1710 \\
\hline
\end{tabular}




\section{List of Tables}

Number

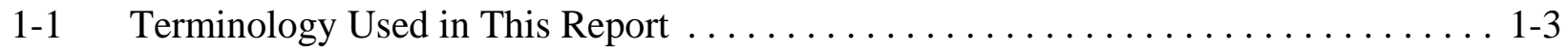

1-2 Hydrogeologic Units of the Nevada Test Site .................... 1-10

2-1 Types of Geophysical Logs and Possible Responses to Faults . . . . . . . . . . . . 2-8

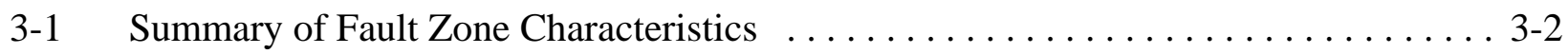


This page intentionally left blank. 


\section{List of Acronyms and Abbreviations}

$\begin{array}{ll}\text { AA } & \text { alluvial aquifer } \\ \text { BN } & \text { Bechtel Nevada } \\ \text { CA } & \text { carbonate aquifer } \\ \text { CAU } & \text { corrective action unit } \\ \text { CCU } & \text { clastic confining unit } \\ \text { cm } & \text { centimeter(s) } \\ \text { ft } & \text { foot (feet) } \\ \text { GCU } & \text { granite confining unit } \\ \text { HFM } & \text { hydrostratigraphic framework model } \\ \text { HGU } & \text { hydrogeologic unit } \\ \text { HSU } & \text { hydrostratigraphic unit } \\ \text { IICU } & \text { intra-caldera intrusive confining unit } \\ \text { in. } & \text { inch(es) } \\ \text { LFA } & \text { lava-flow aquifer } \\ \text { m } & \text { meter(s) } \\ \text { NRC } & \text { National Research Council } \\ \text { NSTec } & \text { National Security Technologies, LLC } \\ \text { NTS } & \text { Nevada Test Site } \\ \text { PCU } & \text { playa confining unit } \\ \text { TCU } & \text { tuff confining unit } \\ \text { UGTA } & \text { Underground Test Area } \\ \text { USGS } & \text { U.S. Geological Survey } \\ \text { VTA } & \text { vitric-tuff aquifer } \\ \text { WTA } & \text { welded-tuff aquifer } \\ & \end{array}$


This page intentionally left blank. 


\subsection{Introduction}

Since the initiation of the U.S. Department of Energy, National Nuclear Security

Administration's Underground Test Area (UGTA) environmental restoration sub-project, project scientists, like geoscientists everywhere, have struggled with the role faults play in groundwater flow and contaminant transport. Although it is obvious that faults at the Nevada Test Site (NTS) play a major role with regards to the juxtapositioning of different hydrostratigraphic units (HSUs), the degree to which faults themselves act as groundwater conduits or barriers is poorly understood. The great abundance of faults at the NTS and thus, the potential for faults to significantly affect flow and transport, makes this an important uncertainty.

In addition, the definitions of hydrogeologic units (HGUs) used in the development of HSUs at the NTS are dependent in large part on the characteristics of rock units that influence fracturing. The descriptions of faults presented in this document are meant to illustrate how fault characteristics, including those that can make faults more or less transmissive, can vary among HGUs. An understanding of fault characteristics and how they vary with HGU may enable modelers to develop more realistic groundwater flow models.

\section{$1.1 \quad$ Purpose and Scope}

The purpose of this study was to provide field- and observation-based information on the characteristics of faults and associated permeability structures in HGUs at the NTS, so that these important and ubiquitous structural features can be more realistically represented and evaluated in various UGTA models. Because HGUs are the basic building blocks for HSUs that form the unit volumes in the hydrostratigraphic framework models (HFMs), information from this study can be applied throughout all the flow and transport models being constructed at the Corrective Action Unit (CAU) scale.

The main effort of the study was to gather observational data on faults and associated permeability structures from a variety of data sources and HGUs, emphasizing attributes important to groundwater flow. The data were compiled and analyzed with respect to the associated HGU. The main source of information was surface exposures; however, tunnel exposures (historical photos, geologists’ notes, etc.), core samples, and geophysical logs were also used. Observations were compared and contrasted with other fault studies to gain additional insights into the possible roles that faults and associated permeability structures play in the movement of groundwater at the NTS. This report does not provide some important quantitative data such as fracture aperture and spacing associated with fault zones, which was beyond the 
scope of this study. It should be realized, however, that detailed information on such parameters is very difficult, if not impossible, to accurately measure and determine in a complex geologic setting such as the NTS.

\subsection{Overview of Faults and Associated Permeability Structures}

Because the intended audience for this document includes UGTA scientists and stakeholders who are not necessarily geologists, and because of a general lack of consistency in terminology for structural features such as faults and fractures (Schultz and Fossen, 2008), this section provides explanations and definitions of the fault-related characteristics and terminology used in this report (Table 1-1).

Faults are fractures in rocks that have experienced relative movement, or offset, of the two opposing sides of the fracture along and parallel to the fracture. Fractures that have not experienced any fracture-parallel offset but instead have "popped open” are termed joints. Faults form in response to stresses applied to a brittle rock mass. These stresses can be compressional, shear, or extensional. In this report we will use the term fault to refer to the main zone of slip, or offset (also called the fault core zone; see Section 1.2.2.1). We will use the term smaller-scale faults to refer to small-offset faults related to the master fault that occur within the damage zone (see Section 1.2.2.2 for definition of damage zone) of the master fault. All other "cracks," such as shear fractures with micro-scale offset and joints that occur within the damage zone, will be referred to as fractures.

For an inclined fault, the overlying fault block is referred to as the hanging wall block, and the underlying block as the footwall block. These relationships can be visualized in a simple fashion by a hypothetical tunnel driven along an inclined fault as illustrated in Figure 1-1A. A person in the tunnel will be standing on the footwall and looking up at the hanging wall.

Faults can be classified into three basic types based on the orientation of the fault plane and the relative movement of the adjacent fault blocks (Figure 1-1B). Normal faults are inclined faults where the hanging wall has moved down the fault plane relative to the footwall. By contrast, reverse faults are inclined faults where the hanging wall has moved up the fault plane relative to the footwall. Low-angle (dips less than 45 degrees) reverse faults are typically referred to as thrust faults. Thrust faults can have reverse offset measured in tens of kilometers. Strike-slip faults are typically very high-angle faults where the adjacent fault blocks have moved horizontally relative to each other. 


\section{Table 1-1 \\ Terminology Used in This Report}

\begin{tabular}{|c|c|}
\hline Damage zone & $\begin{array}{l}\text { The region extending out and away from the fault core in both the hanging wall and } \\
\text { footwall containing deformation features related to movement along the fault. }\end{array}$ \\
\hline Deformation band & $\begin{array}{l}\text { A type of structural discontinuity consisting of millimeter-thick tabular zones } \\
\text { accommodating millimeter- to centimeter-scale slippage in rock units. Slippage is } \\
\text { accomplished by grain boundary sliding, grain fragmentation, and porosity } \\
\text { reduction. }\end{array}$ \\
\hline Fault zone & $\begin{array}{l}\text { The total zone of structural influence of a fault. It includes the fault core and } \\
\text { associated damage zones. }\end{array}$ \\
\hline Fault core & $\begin{array}{l}\text { The relatively narrow zone where most of the fault offset is accommodated. } \\
\text { Synonymous with fault. }\end{array}$ \\
\hline Fault gouge & $\begin{array}{l}\text { Very-fine grained clay-like material produced by the grinding and pulverizing of } \\
\text { rock material within a fault during fault development. }\end{array}$ \\
\hline Fault & $\begin{array}{l}\text { A type of fracture where there has been relative movement, or offset, on a macro- } \\
\text { scale, of the two opposing sides of the fracture along and parallel to the strike of } \\
\text { the fracture. Synonymous with fault core. }\end{array}$ \\
\hline Fault drag & $\begin{array}{l}\text { The frictional pushing up or pulling down of beds adjacent to a fault by movement } \\
\text { along the fault. Synonymous with drag folding. }\end{array}$ \\
\hline Footwall & The underlying fault block associated with an inclined fault. \\
\hline Fracture & $\begin{array}{l}\text { A structural discontinuity in a rock; includes faults, shear fractures, and joints. } \\
\text { Mainly used in this report to refer to shear fractures and joints in the damage } \\
\text { zones of faults. }\end{array}$ \\
\hline Hanging wall & The overlying fault block associated with an inclined fault. \\
\hline Joint & $\begin{array}{l}\text { A type of fracture in which there has been no fracture-parallel offset (i.e., shear } \\
\text { movement). }\end{array}$ \\
\hline Protolith & $\begin{array}{l}\text { The country rock beyond the damage zone, which exhibits little or no fault-related } \\
\text { damage. }\end{array}$ \\
\hline Shear fracture & $\begin{array}{l}\text { A type of fracture with micro-scale movement of the two opposing sides of the } \\
\text { fracture along and parallel to the strike of the fracture. }\end{array}$ \\
\hline Slickensides & $\begin{array}{l}\text { A polished surface with striations and grooves formed by frictional movement } \\
\text { along the fault. }\end{array}$ \\
\hline Smaller-scale fault & $\begin{array}{l}\text { Minor faults that occur within the damage zone. Smaller-scale faults typically } \\
\text { strike parallel with the main fault and dip either in the same (i.e., synthetic), or } \\
\text { opposite (i.e., antithetic), direction than the main fault. }\end{array}$ \\
\hline
\end{tabular}


A.

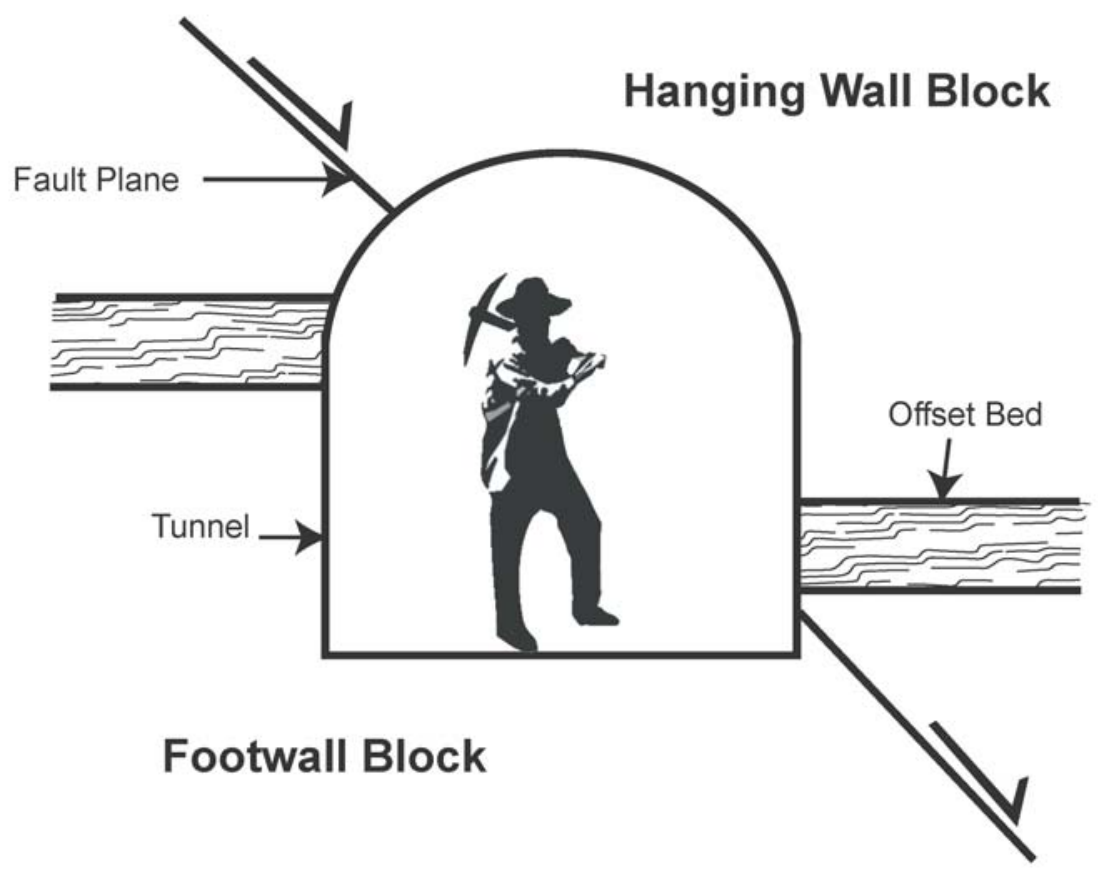

B.

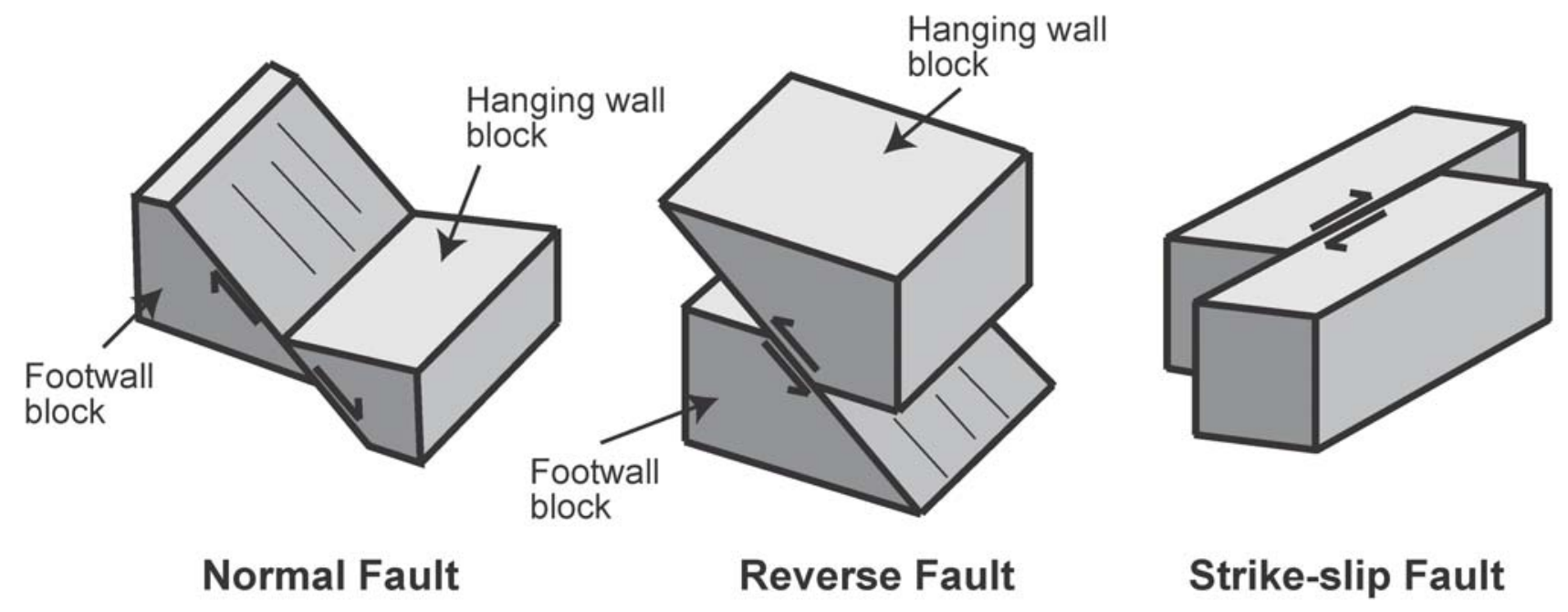

Figure 1-1

Schematic Diagrams Illustrating Fault Block Relationships 


\subsubsection{Faults at the NTS}

The structural geology of the NTS region is very complex and is dominated by faults. As a consequence, faults are ubiquitous at the NTS and include normal, reverse, thrust, and strike-slip faults formed by both compressional and extensional forces. Normal faults, related to generally east-west-directed, basin-and-range extension during the past 11 million years, are dominant structural features in the eastern and southern portions of the NTS. These faults control much of the topographic character in the area, and played significant roles in the development of structural basins such as Yucca Flat and Frenchman Flat. Normal faults range in size from small faults with millimeters of offset, to large basin-forming faults such as the Yucca, Topgallant, and Carpetbag faults that have more than 300 meters (m) (1,000 feet [ft]) of offset. Most normal faults in the NTS region strike in a general north-south direction and dip steeply either to the east or west, reflecting the general east-west extensional stress direction.

Reverse and thrust faults are common in the older (i.e., Pre-Tertiary) sedimentary rocks of the NTS. These faults formed as a result of generally east-west-directed compression between 200 and 100 million years ago (Cole and Cashman, 1999). Large thrust faults such as the Belted Range and CP thrust faults are major structural features at the NTS, and these faults offset and shuffled the Pre-Tertiary rocks. Evidence suggests that some of these older faults were reactivated during basin-and-range extension as normal faults. For example, reactivation of the CP thrust fault appears to have played a major role in the development of Yucca Flat (Burkhard and McArthur, 1985; Bechtel Nevada [BN], 2006).

Strike-slip faults are important structural features in the southern portion of the NTS. These faults generally strike in a northeast-southwest direction and are also related to basin-and-range extension. Strike-slip faults at the NTS include the Rock Valley, Cane Spring, and Mine Mountain faults. These faults appear to have played a significant role in the development of Frenchman Flat (BN, 2005), CP Basin, and Mid Valley, respectively.

Caldera faults are large faults that accommodated catastrophic collapse associated with largevolume pyroclastic eruptions that caused caldera formation. Six known calderas are located on or near the NTS. They range in age from approximately 14 to 9 million years old (Sawyer et al., 1994).

Most of the observations in this study are from normal faults related to basin-and-range extension. This is mainly because they are the most abundant, best exposed, and youngest faults, and they offset most HGUs. 


\subsubsection{Fault Zone Architecture}

Most faults, both in nature and those simulated in the laboratory, significantly deform the rocks in the immediate vicinity of the fault (National Research Council [NRC], 1996), resulting in a zone of deformation referred to as a fault zone. A general model for fault zones, consisting of three basic architectural components, is now widely accepted by many workers (Rawling et al., 2001; Caine et al., 1996). These components are the fault core, damage zones, and protolith, and are illustrated schematically in Figure 1-2. All three of these fault zone architectural components, as well as many of their internal characteristics, are recognized in NTS fault zones.

Some workers (Heynekamp et al., 1999; Minor and Hudson, 2006) recognize a fourth component called the mixed zone that includes characteristics of both the core and damage zones. The mixed zone, which is typically seen in poorly lithified sediments and requires good exposures to delineate, was not demarcated in this study due to the scarcity both of fault exposures in poorly lithified sediments (e.g., alluvium), and of good fault exposures in general.

\subsubsection{Fault Core}

The fault core is the relatively narrow zone where most of the fault offset is accommodated through slippage along one or more closely spaced and linked fault planes (Caine et al., 1996). This slippage is usually accompanied by collapse of in-situ matrix porosity and fragmentation and granulation of the wall rock, and results in the formation of fault-core material ranging from coarse breccia and sand-sized, granulated material to very fine-grained, clay-rich fault gouge. Rocks adjacent to a developing fault can be entrained, or smeared, into the fault core (Aydin and Eyal, 2002; Yielding et al., 1997). Reduction of both porosity and grain-size in fault cores typically yields fault cores with porosity and permeability significantly less than the adjacent wall rock, and leads to fault cores behaving as barriers to groundwater flow (Caine et al., 1996; Lockner et al., 2000).

\subsubsection{Damage Zones}

Extending out and away from the fault core in both the hanging wall and footwall rocks of most faults is a damage zone containing deformation features related to movement along the fault. Fault-related deformation features in damage zones include shattered and brecciated zones, fractures, smaller-scale antithetic and synthetic faults, deformation bands, and fault-related folding referred to as fault drag or drag folding (Figure 1-2). With the exception of deformation bands and core zones of the smaller-scale faults, structural features within damage zones tend to enhance permeability generally by the formation of additional fracture networks (Goodwin et al., 

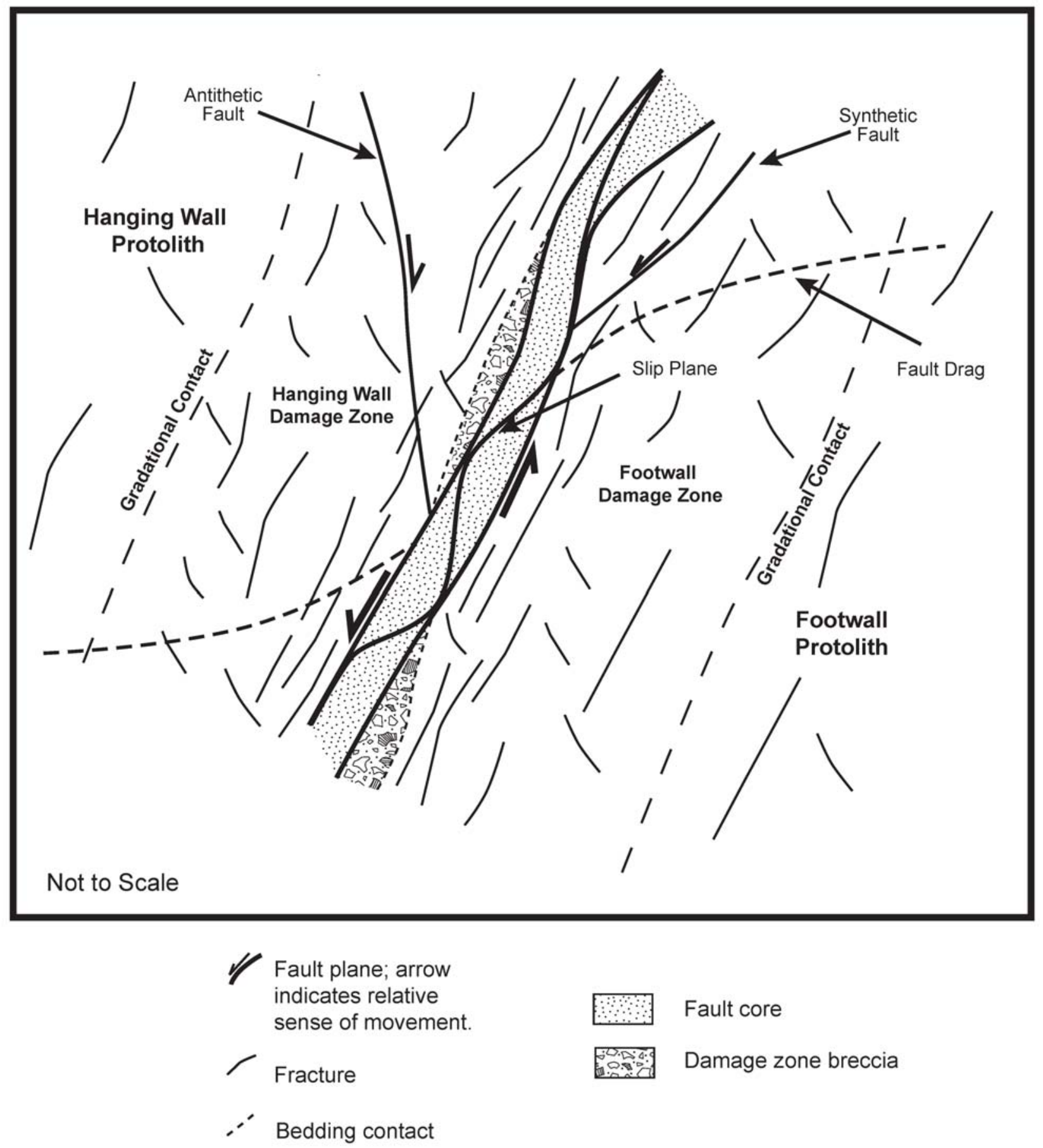

Figure 1-2

Schematic Cross-Sectional View Across a Fault Zone Showing Architectural Components and Associated Structural Features 
1999; Lockner et al., 2000; Caine et al., 1996). The transition from fault core to damage zone is typically abrupt and commonly demarcated by fault slip planes (Caine et al., 1996; Evans et al., 1997).

Deformation bands are millimeter-thick tabular zones accommodating millimeter- to centimeterscale slippage in rock units (Fossen and Bale, 2007; Wilson et al., 2003). Slippage is accomplished by grain boundary sliding, grain fragmentation, and porosity reduction. Deformation bands are common structural features of fault zones in porous sediments and weakly consolidated rocks like unaltered, glassy nonwelded tuff. In saturated conditions, and particularly if cemented, deformation bands most likely act as very narrow tabular zones of reduced permeability and can be three to four orders of magnitude less permeable than the protolith (Antonellini and Aydin, 1994; 1995). However, under unsaturated conditions in semiarid to arid climates, deformation bands can be up to six orders of magnitude more permeable than the protolith (Wilson et al., 2003).

\subsubsection{Protolith}

The surrounding country rock beyond the damage zone, which exhibits little or no fault-related damage, is called the protolith. The protolith may have permeability features, but these will not be directly related to faulting (e.g., cooling joints in welded ash-flow tuff). The transition from damage zone to protolith is typically gradational (Caine et al., 1996; Evans et al., 1997).

\subsection{Factors Controlling Fault-Related Fluid-Flow Properties}

Fault zones are heterogeneous features with fault-related flow properties that vary both in space and time (Caine et al., 1996; Evans et al., 1997; Rawling et al., 2001). Fault zone architectural components provide a first-order variability resulting from potential permeability differences between the protolith, damage zone, and fault core. For example, a fault core may form a relatively narrow tabular flow barrier sandwiched between damage zones with enhanced permeability compared to the more extensive protolith.

Because fault-related deformation evolves differently in different rock types (NRC, 1996), characteristics of damage zones, including flow properties, will also vary according to rock type (i.e., HGU) along a fault. For example, damage zones in highly porous rocks such as sandstones and poorly lithified sediments tend to have permeability values several orders of magnitude less than the protolith due to the development of deformation bands (Antonellini and Aydin, 1994; 1995) and the general absence of fault-related fracture networks (Heynekamp et al., 1999; Sigda et al., 1999). In contrast, damage zones in low porosity crystalline rocks and lithified 
sedimentary rocks are characterized by the development of fault-related fracture networks that can result in permeability values greater than the protolith (Goodwin et al., 1999; Caine et al., 1996).

Fault zone properties also vary temporally due to filling of open fractures with secondary minerals such as calcite (Caine et al., 1996; Evans et al., 1997). For example, a damage zone may be a zone of enhanced fracture permeability during active faulting, but later become a zone of low permeability due to mineral precipitation within open fractures, and then become a conduit again with renewed faulting.

Fault zone permeability can vary according to the orientation of the fault and associated fractures relative to the current stress regime. Barton et al. (1995) and Hickman et al. (1997) showed that the most permeable fractures within damage zones are those parallel to potentially active faults oriented for failure in the current stress regime.

Although it would seem intuitive that larger faults with greater amounts of offset would have wider damage zones characterized by more intense damage, a correlation between fault offset and fault zone width and damage has not yet been firmly established (e.g., Minor and Hudson, 2006; Hull, 1988; Blenkinsop, 1989; Evans, 1990). Minor and Hudson (2006) suggest that there may be a threshold beyond which fault zones no longer widen. Caine et al. (1996) suggested that wider damage zones may indicate episodic movement along a fault.

\subsection{Hydrogeologic Units at the NTS}

UGTA CAU-scale HFMs are developed from a two-level hydrostratigraphic system consisting of HGUs that are grouped into larger HSUs that form the unit volumes of the HFMs (National Security Technologies, LLC [NSTec], 2007). Within the UGTA CAU-scale hydrostratigraphic system, HGUs categorize rock units as aquifers and confining units according to the nature of their porosity and permeability. As listed in Table 1-2, rocks in the NTS area are classified as one of ten HGUs based mainly on the rock's primary lithology, type and degree of postdepositional alteration, and propensity to fracture (Winograd and Thordarson, 1975; BN, 2005; 2006; NSTec, 2007). Because these 10 HGUs are the building blocks for all 76 HSUs, analyzing the nature of faults and associated permeability structures with respect to individual HGUs allows relevant information to be applied throughout all the HFMs. Although examples of faults were found in only five of the ten HGUs during this study, some relevant inferences can be made for the remaining five HGUs. 
Table 1-2

Hydrogeologic Units of the Nevada Test Site

(Adapted from Winograd and Thordarson [1975] and Laczniak et al. [1996])

\begin{tabular}{|c|c|c|}
\hline Hydrogeologic Unit & Typical Lithologies & Hydrologic Significance \\
\hline $\begin{array}{l}\text { Alluvial aquifer } \\
\qquad(A A)\end{array}$ & $\begin{array}{l}\text { Unconsolidated to partially } \\
\text { consolidated gravelly sand, } \\
\text { eolian sand, and colluvium }\end{array}$ & $\begin{array}{l}\text { Has characteristics of a highly conductive aquifer, } \\
\text { but less so where lenses of clay-rich } \\
\text { paleocolluvium or zeolitic alteration are present. }\end{array}$ \\
\hline $\begin{array}{l}\text { Welded-tuff aquifer } \\
\text { (WTA) }\end{array}$ & $\begin{array}{l}\text { Welded ash-flow tuff; vitric to } \\
\text { devitrified }\end{array}$ & $\begin{array}{l}\text { Degree of welding greatly affects interstitial } \\
\text { porosity (i.e., less porosity as degree of welding } \\
\text { increases) and permeability (i.e., greater fracture } \\
\text { permeability as degree of welding increases). }\end{array}$ \\
\hline $\begin{array}{l}\text { Vitric-tuff aquifer } \\
\quad \text { (VTA) }\end{array}$ & $\begin{array}{l}\text { Bedded tuff; ash-fall and } \\
\text { reworked tuff; vitric }\end{array}$ & $\begin{array}{l}\text { Constitutes a volumetrically minor HGU. } \\
\text { Generally does not extend far below the static } \\
\text { water level due to tendency of tuff to become } \\
\text { zeolitic under saturated conditions, which } \\
\text { drastically reduces permeability. Significant } \\
\text { interstitial porosity (i.e., } 20 \text { to } 40 \text { percent). } \\
\text { Generally insignificant fracture permeability. }\end{array}$ \\
\hline $\begin{array}{l}\text { Lava-flow aquifer } \\
\text { (LFA) }\end{array}$ & $\begin{array}{l}\text { Rhyolite, basalt, and dacite } \\
\text { lava flows; includes flow } \\
\text { breccia (commonly at base) }\end{array}$ & $\begin{array}{l}\text { Generally occurs as small, moderately thick } \\
\text { (rhyolite) to thin (basalt) local flows. } \\
\text { Hydrologically complex, showing a wide range of } \\
\text { transmissivity values. Fracture density and } \\
\text { interstitial porosity differ with lithologic variations. }\end{array}$ \\
\hline $\begin{array}{l}\text { Playa confining unit } \\
\text { (PCU) }\end{array}$ & Silt and clay & $\begin{array}{l}\text { Near-surface confining unit at Yucca and } \\
\text { Frenchman Lakes and within lower portion of } \\
\text { alluvial section in the deepest portions of } \\
\text { Frenchman Flat. }\end{array}$ \\
\hline $\begin{array}{l}\text { Tuff confining unit } \\
\text { (TCU) }\end{array}$ & $\begin{array}{l}\text { Zeolitic bedded tuff with } \\
\text { interbedded, but less } \\
\text { significant, zeolitic, } \\
\text { nonwelded to partially } \\
\text { welded ash-flow tuff }\end{array}$ & $\begin{array}{l}\text { May be saturated but measured transmissivity } \\
\text { values are very low. May cause semi-perched } \\
\text { conditions. }\end{array}$ \\
\hline $\begin{array}{l}\text { Intra-caldera intrusive } \\
\text { confining unit (IICU) }\end{array}$ & $\begin{array}{l}\text { Highly altered, highly } \\
\text { injected/intruded country } \\
\text { rock and granitic material }\end{array}$ & $\begin{array}{l}\text { Assumed to be impermeable. Conceptually } \\
\text { underlies each of the southwest Nevada volcanic } \\
\text { field calderas. Developed for the HFMs to } \\
\text { designate basement beneath calderas as different } \\
\text { from basement outside calderas. }\end{array}$ \\
\hline $\begin{array}{l}\text { Granite confining unit } \\
\text { (GCU) }\end{array}$ & Quartz monzonite & $\begin{array}{l}\text { Saturated at depth, but because of low inter- } \\
\text { granular porosity and permeability, plus the lack of } \\
\text { inter-connecting fractures, is considered a } \\
\text { confining unit. }\end{array}$ \\
\hline $\begin{array}{l}\text { Clastic confining unit } \\
\text { (CCU) }\end{array}$ & Argillite, siltstone, quartzite & $\begin{array}{l}\text { Siliciclastic rocks are relatively impermeable; } \\
\text { coarser grained siliciclastic rocks are fractured, } \\
\text { but with fracture porosity generally sealed due to } \\
\text { secondary mineralization. }\end{array}$ \\
\hline $\begin{array}{l}\text { Carbonate aquifer } \\
\text { (CA) }\end{array}$ & Dolomite, limestone & $\begin{array}{l}\text { Transmissivity values vary greatly and are directly } \\
\text { dependent on fracture frequency. }\end{array}$ \\
\hline
\end{tabular}




\subsection{Fault Data}

The authors sought information about NTS fault characteristics from many sources. Much of the information presented here is from surface and tunnel exposures of faults; however, core holes, and geophysical logs were also examined. This section describes these data sources used to document fault data. Also included are comments regarding the usefulness or limitations of the data obtained from the various types of sources.

Annotated photographs of many of the faults studied are provided in Appendix A. Throughout this and following sections reference to figures that include "A-" in the figure number will be found in the indicated section of Appendix A.

\section{$2.1 \quad$ Surface Exposures}

Much of the information on the nature of faults and associated permeability structures presented here was acquired from surface exposures where fault attributes could be directly observed and measured. It should be noted, however, that despite the magnitude of faulting, considerable topographic relief, and relatively sparse vegetation, faults are typically not very well exposed at the NTS. This is mainly due to typical weathering and erosion effects, including the covering of fault zones by colluvium. Consequently, few individual fault exposures provided information on all of the desired attributes relating to the fault core and adjacent damage zones. Most exposures did, however, provide useful information on some aspect of at least one attribute, and, taken together, fault exposures documented in this study provide useful insights into the nature of both fault core zones and their related damage zones in a variety of HGUs.

Although surface exposures typically provided the most informative data regarding faults and associated permeability features, caution should be exercised when extrapolating surface fault data to the subsurface. Weathering, erosion, and reduction of overburden confining pressures can have significant effects on pre-existing deformation features, particularly fracture aperture. Still, fault exposures provided relevant information on the general character of fault cores and associated damage zones that can, at the least, provide a general, yet important, "reality check" on the techniques and processes utilized to model fault and fault zones in the UGTA flow and transport models.

Fifteen surface exposures of faults were studied. Most are located in the eastern portion of the NTS (Figure 2-1) where the magnitude of basin-and-range extension is greatest, resulting in a 


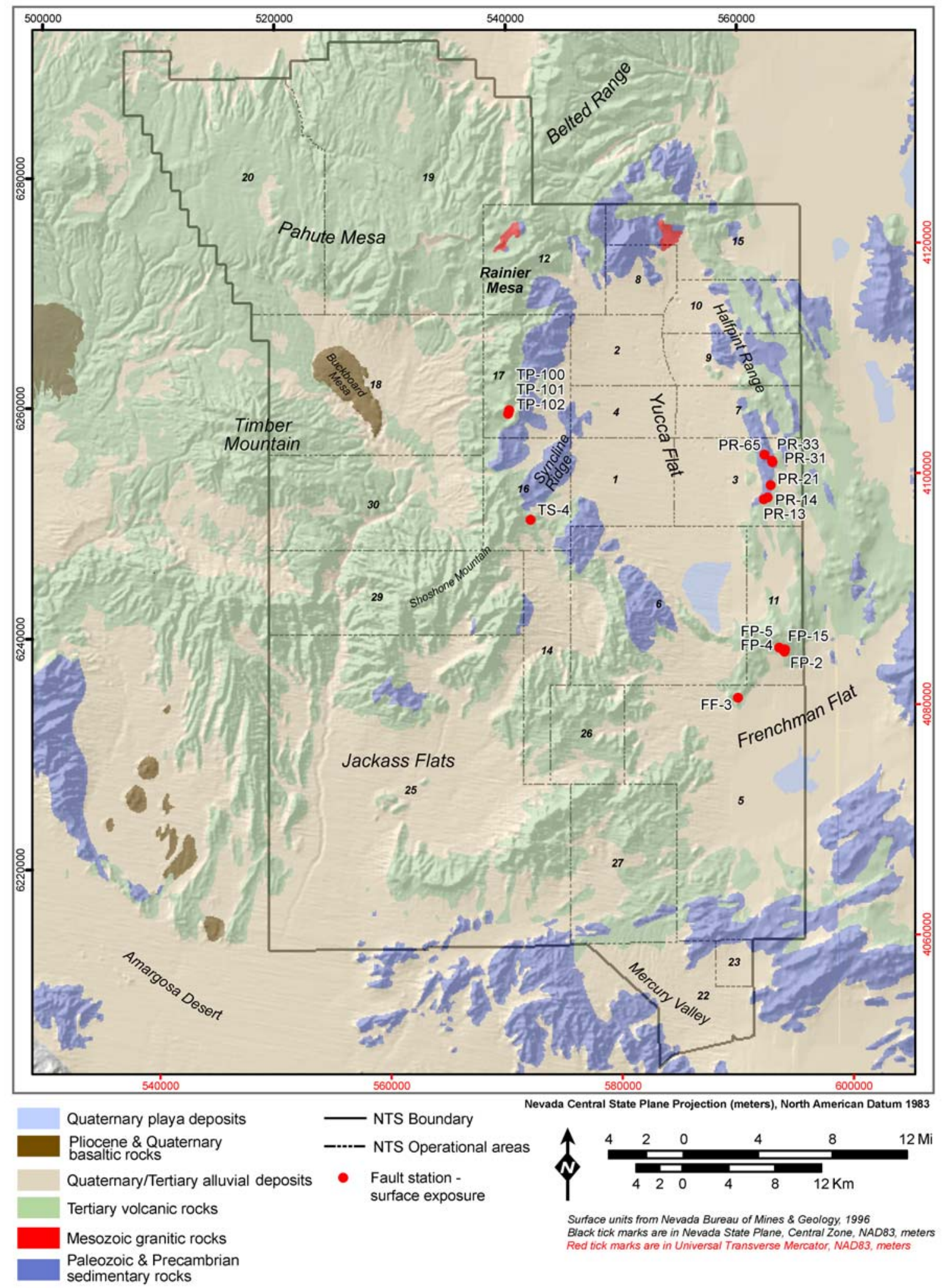

Figure 2-1

Generalized Geologic Map Showing Locations of Fault Stations with Surface Exposures 
greater abundance of faults, particularly normal faults. Faults were observed in a variety of HGUs including welded-tuff aquifer (WTA), vitric-tuff aquifer (VTA), tuff confining unit (TCU), alluvial aquifer (AA), and carbonate aquifer (CA). Geologic quadrangle maps published by the U.S. Geological Survey (USGS) were used to help locate potential fault exposures. Faults with data such as orientation, dip, plunge of slickensides, etc., noted on maps were of particular interest when selecting sites to visit because such information indicates that the fault plane is exposed. Photographs of the sites are provided in Appendix A (Figures A-1 through A-23).

\subsection{Tunnel Exposures}

Tunnels provide a unique opportunity for studying geologic features such as subsurface faults. Tunnel walls, like road-cuts, typically provide fresh, unweathered, clean exposures. Also, tunnels allow one to literally walk into and be surrounded by a geologic feature, providing a three-dimensional perspective difficult to obtain in other settings. On the other hand, tunnels are relatively small in diameter, so typically only a limited portion of a feature is available for observation. Also, as with surface exposures, some caution is required when extrapolating geologic observations in tunnels, mainly because of the potential effects of stress relief and mechanical damage that may occur during mining activities.

More than 80 kilometers (50 miles) of tunnels have been mined at the NTS and many have a long history of detailed geologic data collection and analysis. Observations of faults intersected in three tunnels were used for this investigation, U12n (N-Tunnel) and U12t (T-Tunnel) tunnels at Rainier Mesa and the U1a Complex in Yucca Flat (Figure 2-2).

\subsubsection{Rainier Mesa Tunnels}

$\mathrm{N}$-Tunnel and T-Tunnel each consist of a large complex of drifts and alcoves mined into the eastern flank of Rainier Mesa. Both tunnel complexes were mined entirely within zeolitic tuff, and thus provide an opportunity to observe fault characteristics within TCU. Secondary silica appears to be much more common in T-Tunnel rocks, and these silicified beds are stronger and more consolidated than typical TCU consisting of zeolitic alteration only. This apparent difference in alteration between the two tunnels is reflected in fault characteristics, with more damage typically associated with faults in T-Tunnel. Both tunnels are now closed, and were inaccessible for this investigation. However, numerous photographs of faults taken during mining, and accompanying geologists’ notes about faults were available. Because Rainier Mesa 


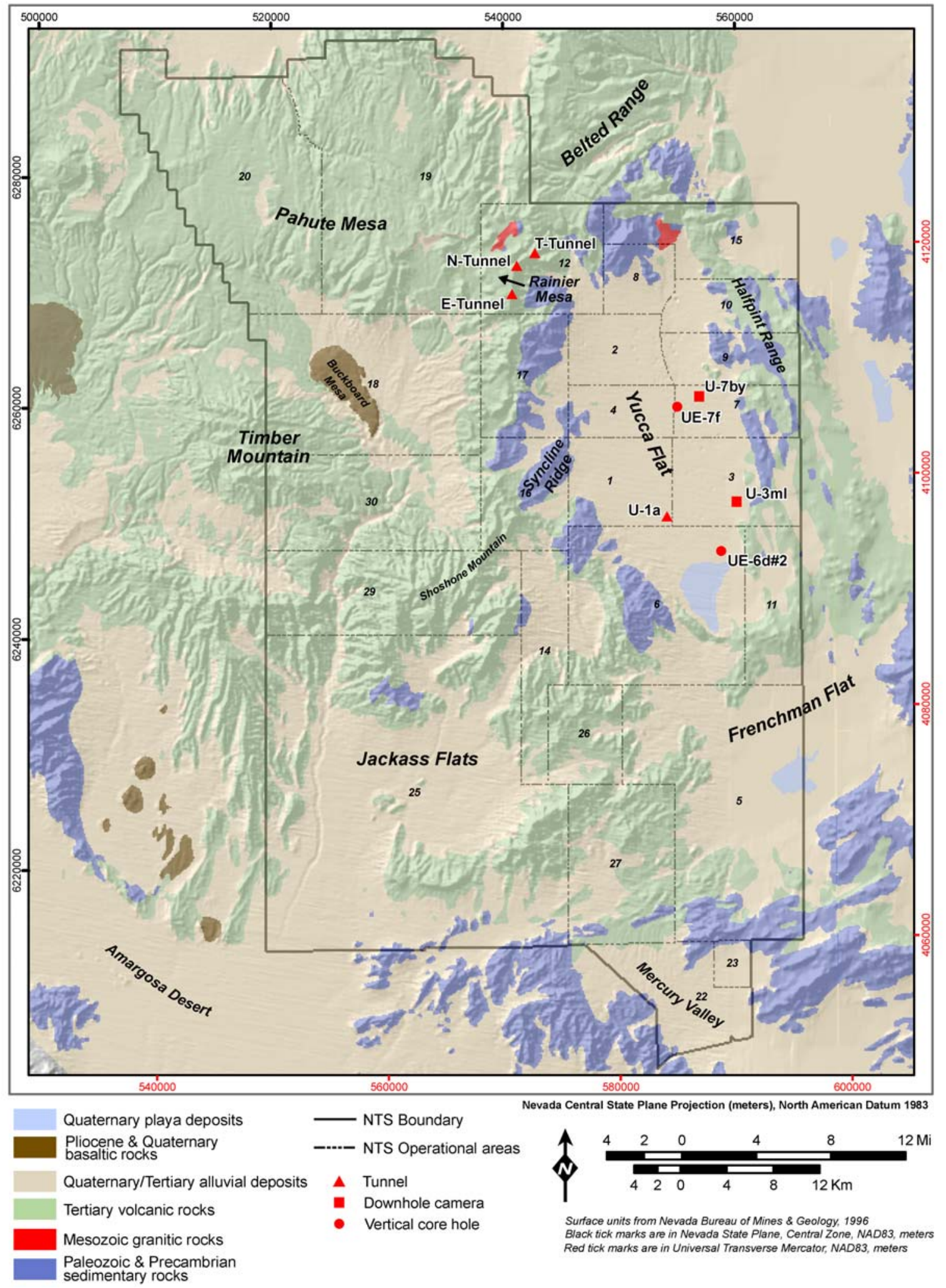

Figure 2-2

Generalized Geologic Map Showing Locations of Fault Stations Associated with Tunnels, Down-Hole Cameras, and Vertical Core Holes 
lies within an area of minimal extension (Sawyer et al., 1994), faults are not that common and most are relatively small, with offsets typically less than $6 \mathrm{~m}(20 \mathrm{ft})$.

\subsubsection{U1a Complex}

The U1a Complex is a tunnel complex that lies about $294 \mathrm{~m}(965 \mathrm{ft})$ below the ground surface in southwestern Yucca Flat (Figure 2-2). Access to the horizontal drifts of the U1a Complex is provided by two vertical shafts. The complex is mined entirely within unsaturated Tertiary alluvium, and thus provides a unique opportunity to observe fault characteristics within alluvial aquifer. The faults intersected by the U1a drifts are all normal faults that strike northeastsouthwest and have steep dips. Major faults, such as the Yucca Fault, are not intersected by the U1a Complex; however, five faults display offsets greater than the height of the drift or drifts they intersect (i.e., 3.7 to $5.2 \mathrm{~m}$ [12 to $17 \mathrm{ft}$ ) (Huckins-Gang, 2003). Observations of fault characteristics reported here are based on detailed geologic mapping by NTS contractor geologists during the past two decades.

\subsection{Core Samples}

Core samples provide a continuous lithologic record of the cored interval in a borehole. However, several factors determine the quality of exposure of faults in core samples. The amount of core recovered in an interval can vary, depending mainly on the competency of the rock being drilled. Cemented granular (i.e., clastic) rocks and crystalline rocks are typically competent enough to provide good core recovery. These rocks include quartzite, limestone, dolomite, welded ash-flow tuff, zeolitic tuff, and granite. Poorly consolidated rocks such as vitric nonwelded tuff and poorly cemented alluvium can be difficult to recover in core samples. Also, open and weakly cemented fractures can cause poor core recovery by jamming the core barrel during coring or cause core samples to fall out of the barrel during core retrieval. Thus, full core recovery can be difficult even in competent rocks when they are highly fractured such as in damage zones of faults.

At the NTS core holes were typically drilled in either of two orientations, vertical or nominally horizontal, and produced cylindrical core samples typically less than 10 centimeters $(\mathrm{cm})$ (4 inches [in.]) in diameter. The quantity of exposures of faults in NTS cores depends on the angle of the fault plane relative to the angle of the borehole. High-angle faults are poorly represented in vertical core holes. However, most of the longer horizontal core holes were drilled to explore regions ahead of mining in tunnels, primarily to discover fault zones, and 
numerous examples of fault planes and fault zones are available in cores from Rainier Mesa tunnels. In addition, the quality of exposures of high-angle faults in cores tends to be better in horizontal than in vertical holes.

Core samples from both horizontal and vertical core holes that were reported to have intercepted faults were examined. Core samples from two horizontal holes, U12t.03 UG-1 and U12e.14 UG-3, were examined. These holes were drilled ahead of mining in T-Tunnel and E-Tunnel in Rainier Mesa, and have the advantage of being oriented at high angles to faults. In addition, other data are available from the boreholes, including resistivity and velocity logs (see Section 2.4 for more discussion of these logs) and Core Index logs. The Core Index is a method of using core recovery, breakage, and joint data to produce semi-quantitative geomechanical information, including estimates of rock competence and mineability. It is similar to the industry standard "RQD" method, and was developed by the USGS for use at the NTS (Ege, 1987). In practice, during active mining in the Rainier Mesa tunnels, observational logs of core characteristics, stratigraphy (thinned or missing intervals), Core Index, and resistivity and velocity logs were all used by geologists to determine the locations of faults and incompetent rock zones ahead of mining as part of site resource planning. It is important to note, however, that elevated Core Index values indicate that the rock has been mechanically weakened but not necessarily enhanced with regards to permeability.

Certain fault indicators such as polished and striated fault planes (Figures A-37 and A-38) and bedding offset (Figure A-36) can be recognized in core samples and are definitive indicators of faults. However, because some fault zones create areas of incompetent rock due to increased fracturing, core may be missing from all or a portion the fault zone (Figure A-39).

\subsection{Geophysical Logs}

More than 4,000 holes have been drilled at the NTS, resulting in a large and valuable set of subsurface data. This includes thousands of geophysical well logs that measured, either directly or indirectly, rock properties such as competency, radioactivity, bulk density, acoustic velocity, water content, and electrical resistivity. Because fault-related features have the potential to affect many of these properties, geophysical logs were examined in vertical drill holes located in Yucca Flat that were reported to intercept faults to evaluate the use of geophysical logs for identifying and characterizing faults in boreholes.

Locations of borehole fault intercepts were compiled mainly from historic lithologic logs. The original determination of fault intercepts in these holes was based mainly on stratigraphic 
information such as possibly thinned or missing stratigraphic intervals. Some fault intercepts were originally based on visual evidence in core and drill cuttings samples, such as the presence of slickensides and argillic intervals.

A total of 54 fault intercepts was analyzed from 26 boreholes. Logs examined included caliper, resistivity, density, neutron, total gamma ray, velocity, and spectral gamma ray. Rarely, however, were all log types available for analysis in a given hole. Each log was examined in the vicinity of the reported depth of the fault intercept to see if there were any changes in the log signature near the fault. Table 2-1 lists the types of logs, the anticipated response within fault zones, and the possible causative factors for the response. It should be remembered that when one is analyzing high-angle features with a sample set (i.e., log data) acquired in a vertical configuration, the thicknesses of certain architectural components such as fault cores and damage zones may be greatly exaggerated.

Results indicate that there is no unique or definitive geophysical log response that is indicative of a fault. This is because most geophysical log responses can be caused by more than one borehole or geologic condition. For example, borehole enlargement may be caused by a highly fractured interval, such as a damage zone of a fault, or by a poorly consolidated (i.e., less cemented) unit. Most geophysical responses associated with faults are likely related to the potential of increased fracturing within damage zones and the presence of clayey fault gouge in fault cores. Increases in fracturing, however, are not always associated with faults. Welded portions of ash-flow tuffs can have well-developed cooling fractures that form relatively soon after deposition, well before any structural activity.

Although a combination of responses from different logs may suggest the presence of a fault cutting a borehole, other information is typically necessary for a confident determination. This usually requires very good stratigraphic understanding of the area, such as the extent and thickness of the stratigraphic units. Thus, the identification of faults intercepted by drill holes requires information beyond that obtained from just a single drill hole. Even in well characterized areas such as the volcanic section in Yucca Flat, it is very difficult to determine the precise depth of a fault intercept within a vertical borehole, much less characterize its properties, with geophysical logs without very good stratigraphic control (Figure 2-3). This is a very important point that should be considered when planning drilling programs that include fault zone characterization. 
Table 2-1

Types of Geophysical Logs and Possible Responses to Faults

\begin{tabular}{||l|l|l||}
\hline \multicolumn{1}{||}{ Log Type } & $\begin{array}{l}\text { Anticipated Most Likely Fault- } \\
\text { Related Response } \\
\text { (compared to protolith) }\end{array}$ & \multicolumn{1}{|c||}{ Possible Cause } \\
\hline \hline Caliper & Borehole enlargement & $\begin{array}{l}\text { Borehole instability resulting from } \\
\text { increased fracturing in damage zones and } \\
\text { poorly consolidated cataclastic material } \\
\text { and clayey gouge in fault cores. }\end{array}$ \\
\hline Resistivity & Lower resistivity values & $\begin{array}{l}\text { Increase in the number of open fluid-filled } \\
\text { fractures in damage zones and presence } \\
\text { of clayey fault gouge in fault core zone }\end{array}$ \\
\hline Density & Lower bulk density values and & $\begin{array}{l}\text { Increase in the number of fractures in } \\
\text { damage zones and presence of clayey } \\
\text { fault gouge in fault core zone }\end{array}$ \\
\hline Neutron & lower calculated porosity. \\
lower calculated porosity & $\begin{array}{l}\text { Increase in the number of water-filled } \\
\text { fractures in damage zones and presence } \\
\text { of clayey fault gouge in fault core zone }\end{array}$ \\
\hline $\begin{array}{l}\text { Total Gamma Ray and } \\
\text { Spectral Gamma Ray }\end{array}$ & $\begin{array}{l}\text { Higher natural gamma ray } \\
\text { values }\end{array}$ & $\begin{array}{l}\text { Presence of clayey fault gouge in fault } \\
\text { core zone and increase in uranium due to } \\
\text { precipitation of uranium within fractures of } \\
\text { damage zones. }\end{array}$ \\
\hline $\begin{array}{l}\text { Velocity (horizontal } \\
\text { boreholes) }\end{array}$ & Slower velocities & $\begin{array}{l}\text { Presence of increased fracture density in } \\
\text { damage zone and presence of fine- } \\
\text { grained or clayey fault gouge in fault core } \\
\text { zone. }\end{array}$ \\
\hline
\end{tabular}

\subsection{Borehole Image Logs}

Borehole image logs are produced by electric, acoustic, and video down-hole logging devices that provide an electronic image of the borehole wall (Asquith and Krygowski, 2004). Although image logs are considered to be geophysical logs, they are discussed separately here because of their unique value as a tool for identifying faults and associated structural features. Image data are typically presented as folded-out, two-dimensional color images of the inner walls of boreholes. Thus, planar features cutting through the borehole, such as fractures and bedding planes, are visible as sinusoidal traces in the image logs (Figure 2-4). Because the images are oriented with respect to compass direction, the orientation (i.e., strike and dip) of planar features can be determined. Faults are indicated by the presence of bed terminations as a result of fault offset, abrupt changes in bedding orientation, drag folding indicated by gradual changes in bed dip (Figure 2-5), and an increase in fractures. Although none of these indicators by itself is 


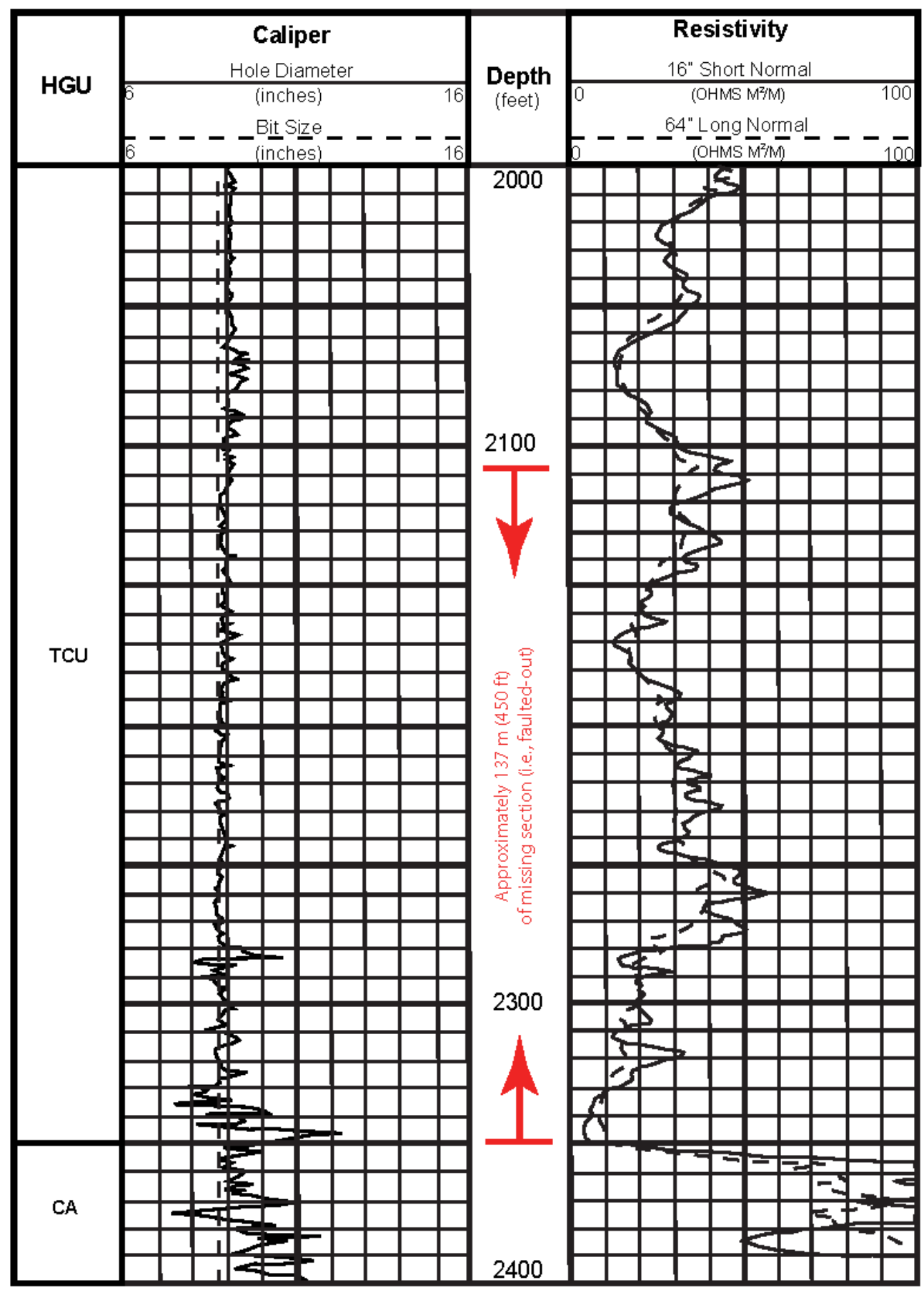

Stratigraphic information indicates that UE-1q intersected the Topgallant fault between the depths of 2110 and 2350 feet (red bracketed interval). Note, however, that the fault is not readily identifiable in the geophysical log data.

Figure 2-3

Portions of the Caliper and Resistivity Logs for Drill Hole UE-1q Showing Log Signatures Across the Topgallant Fault in Yucca Flat 


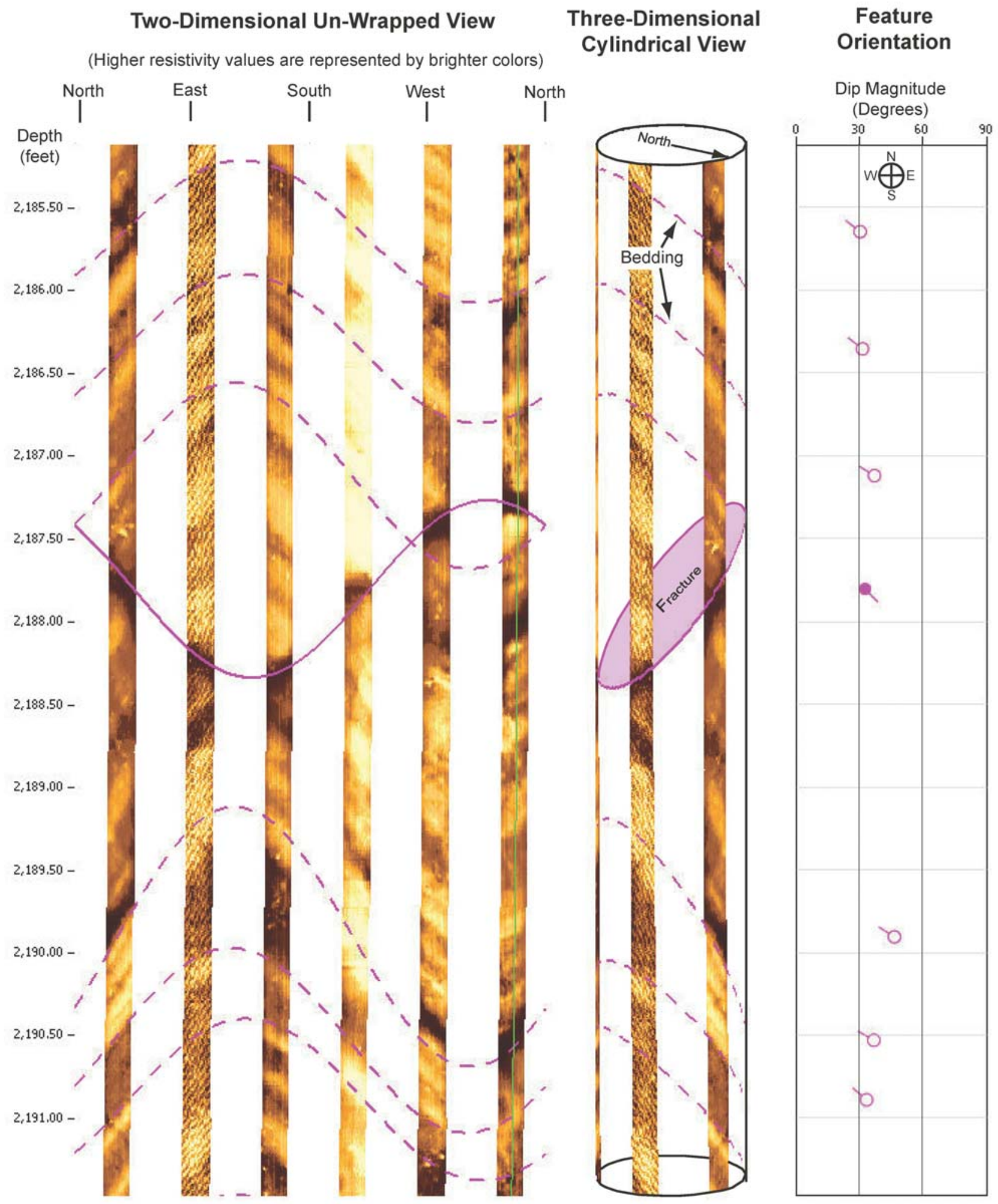

Figure 2-4

A Portion of the Borehole Image Log from UGTA Well ER-16-1 Showing a Fracture Within Highly Bedded Shale 


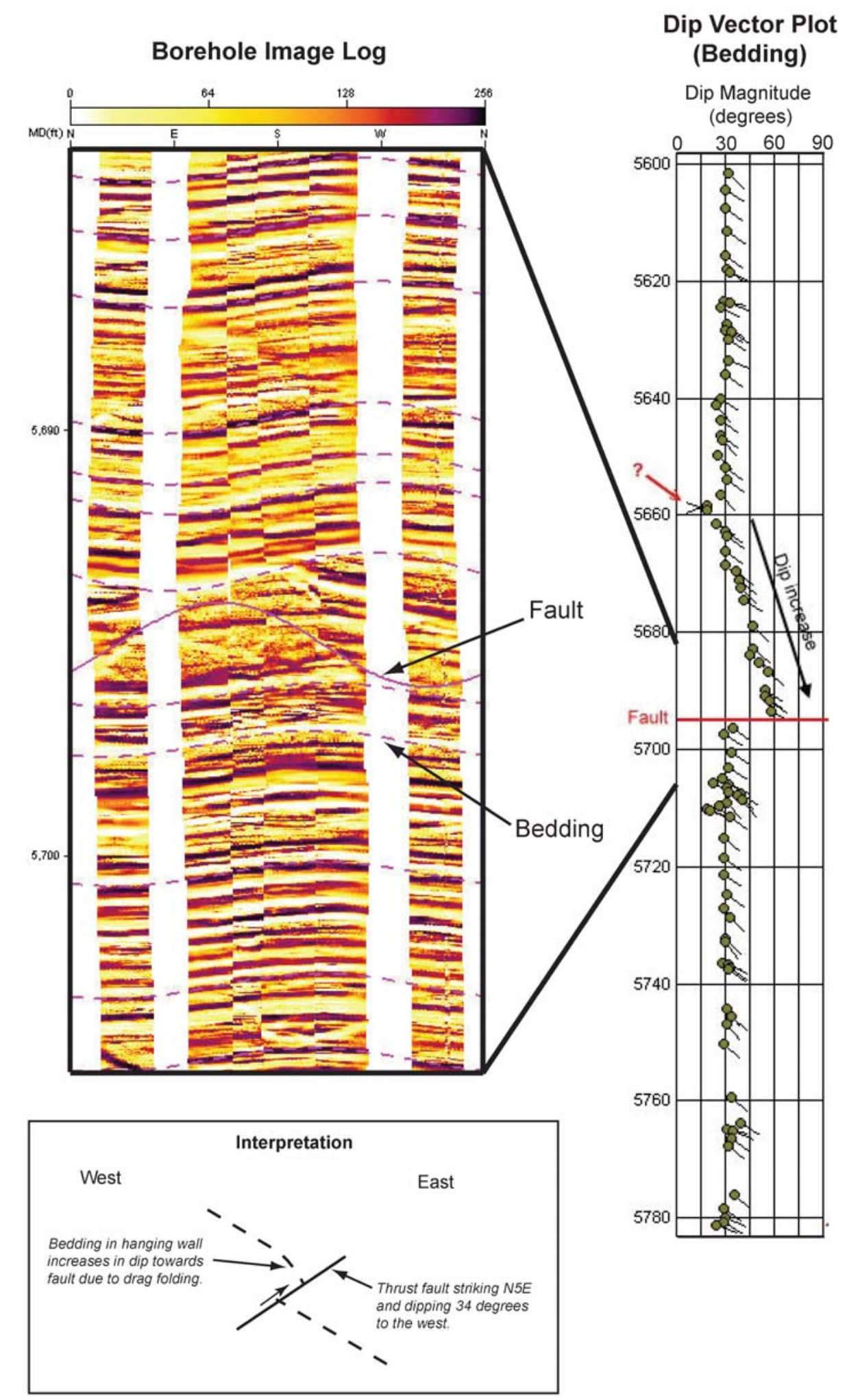

Figure 2-5

A Portion of the Borehole Image Log and Dip Vector Plot for UGTA Well ER-12-2 Showing Drag Folding in the Hanging Wall of a Thrust Fault Cutting the Borehole 
definitive of a fault, if more than one are present in the proper geologic context, then they can be strong indicators of faults.

As with all geophysical log analyses, however, integrating regional and local geology information is critical for accurate fault interpretation. For example, stratigraphic unconformities can have some of the same image characteristics as faults, such as bed terminations and abrupt bedding orientation changes.

Borehole image logs for UGTA Wells ER-12-3 and ER-12-4 were reviewed to evaluate the use of image logs to identify and characterize NTS faults and associated permeability features. These wells were chosen because both wells penetrated thick sections of CA known to be highly deformed but lacking major angular unconformities (Caskey and Schweickert, 1992). Structural complexities resulting from intense deformation of the carbonate rocks penetrated by Wells ER-12-3 and ER-12-4 make fault identification and characterization using borehole image logs difficult and uncertain. Faults tentatively identified in Wells ER-12-3 and ER-12-4 were associated with an increase in fractures, abrupt change in bed orientation, bed drag patterns, and occurrence of breccia intervals, which are characteristics also observed in surface exposures of faults in CA.

\subsection{Down-Hole Video and Photography}

During the Weapons Testing Program at the NTS, cameras were commonly run down largediameter emplacement holes to visually evaluate borehole conditions and features. Video, film, and still photography were acquired in numerous holes. Because known faults were typically avoided when siting test holes, faults are not commonly observed in these down-hole camera runs. During this study, faults were confidently identified in two emplacement holes, U-3mL and U-7by located in Yucca Flat (Figure 2-2). The faults observed in these holes are relatively small, with offsets less than $2 \mathrm{~m}$ (6.6 ft), and are recognized by conspicuous color changes along steeply-dipping elliptical contacts within the borehole (Figure A-40) as well as obvious offsetting of beds (Figure A-41), 


\subsection{Observations and Results}

This section describes characteristics of NTS fault zones based on observations from the various sources described in Section 2.0. General observations of fault core zones and damage zones are provided in Section 3.1, followed in Section 3.2 by observations of fault zone characteristics specific to various HGUs.

\subsection{General Observations}

This section describes general characteristics of fault core zones and damage zones observed associated with NTS faults (Table 3-1). It is important to note that fault zone characteristics observed at the NTS are consistent with observations of fault zones in other regions, which are briefly discussed in Section 1.0 of this report.

\subsubsection{Fault Core Zones}

Many of the cores of faults examined in the field are covered with talus and alluvial deposits and thus were not available for direct observation and measurement. A maximum possible width, however, could usually be estimated by measuring the distance between exposures of hanging wall and footwall rocks across the fault. These measurements indicate that fault cores are relatively narrow features less than $3.0 \mathrm{~m} \mathrm{(10} \mathrm{ft)} \mathrm{wide.} \mathrm{However,} \mathrm{this} \mathrm{should} \mathrm{be} \mathrm{considered} \mathrm{a}$ very rough estimate of the possible maximum width. Well exposed fault core zones intersected by tunnels at the NTS show widths less than $15 \mathrm{~cm}$ (6 in.). Fault core zones observed in downhole cameras and drill cores were also less than $15 \mathrm{~cm}$ (6 in.) wide. Sweetkind and Drake (2007) measured fault core zones at five NTS surface locations, and found that the fault cores ranged from 0.1 to $10 \mathrm{~cm}$ (0.4 to 4 in.) wide. Minor and Hudson (2006) determined a mean core width of $10 \mathrm{~cm}$ (4 in.), with half being less than $5 \mathrm{~cm}$ ( 2 in.) wide, for 101 faults cutting various rock types within the Santo Domingo and northern Albuquerque Basins in New Mexico. In summary, fault core zones examined in this study form relatively narrow zones less than $3 \mathrm{~m} \mathrm{(10} \mathrm{ft)} \mathrm{wide,}$ and possibly considerably less, and compose only a small percentage of the total fault zone (i.e., fault core + damage zones [Section 3.1.2]). This is consistent with widths of fault core zones measured in other studies (e.g., Sweetkind and Drake, 2007; Minor and Hudson, 2006; Lockner et al., 2000). 
Table 3-1

Summary of Fault Zone Characteristics

\begin{tabular}{|c|c|c|c|c|c|c|c|c|c|c|c|c|c|}
\hline \multirow{4}{*}{$\begin{array}{c}\text { Fault } \\
\text { Station } \\
\text { (Figure No.) }\end{array}$} & \multirow{4}{*}{$\begin{array}{l}\text { Data } \\
\text { Type }^{a}\end{array}$} & \multirow{3}{*}{\multicolumn{4}{|c|}{ Fault Orientation and Offset }} & \multicolumn{8}{|c|}{ Architectural Components } \\
\hline & & & & & & \multirow{2}{*}{\multicolumn{2}{|c|}{ Fault Core }} & \multicolumn{6}{|c|}{ Damage Zone } \\
\hline & & & & & & & & \multicolumn{3}{|c|}{ Footwall } & \multicolumn{3}{|c|}{ Hanging Wall } \\
\hline & & Strike & Dip & $\begin{array}{l}\text { Offset } \\
\text { (feet) }\end{array}$ & $\begin{array}{l}\text { Slip } \\
\text { Sense }\end{array}$ & $\begin{array}{l}\text { Width } \\
\text { (feet) }\end{array}$ & Composition $^{b}$ & $\begin{array}{l}\text { Width } \\
\text { (feet) }\end{array}$ & $\begin{array}{l}\text { Permeability } \\
\text { Structures }^{c}\end{array}$ & $H G U^{d}$ & $\begin{array}{l}\text { Width } \\
\text { (feet) }\end{array}$ & $\begin{array}{l}\text { Permeability } \\
\text { Structures }\end{array}$ & HGU d \\
\hline $\begin{array}{l}\text { FF-3 } \\
(A-1)\end{array}$ & sX & N20E & $\sim 90^{\circ}$ & 20 & Normal & 0.3 & GM & 16 & DB & VTA & 0 & No damage & VTA \\
\hline $\begin{array}{l}\text { FP-2 } \\
(A-2)\end{array}$ & sX & N6E & $60^{\circ} \mathrm{SE}$ & $\sim 400$ & Normal & -- & -- & -- & -- & VTA & -- & $\mathrm{BR}$ & WTA \\
\hline $\begin{array}{c}F P-4 \\
(A-5, A-6)\end{array}$ & sx & $\sim N$ & $\mathrm{E}$ & $\sim 400$ & Normal & 6.0 & -- & -- & $\mathrm{FR}$ & TCU & 30 & $\mathrm{FR}$ & WTA \\
\hline $\begin{array}{l}\text { FP-5 } \\
\text { (A-7) }\end{array}$ & sx & $\sim N$ & $\mathrm{E}$ & $\sim 400$ & Normal & -- & -- & -- & $\mathrm{FR}$ & TCU & -- & $\mathrm{FR}$ & WTA \\
\hline $\begin{array}{c}\text { FP-15 } \\
(\mathrm{A}-8, \mathrm{~A}-9)\end{array}$ & $s x$ & $\sim \mathrm{NNE}$ & E & $\sim 400$ & Normal & 10.0 & -- & 25 & $\mathrm{FR}, \mathrm{SF}$ & $\mathrm{TCU}$ & $>22$ & $\mathrm{FR}, \mathrm{DF}$ & VTA \\
\hline $\begin{array}{l}\text { PR-13 } \\
(A-11)\end{array}$ & sX & $\mathrm{N} 25 \mathrm{~W}$ & $70^{\circ} \mathrm{SW}$ & -- & Normal & 5.0 & $\mathrm{FG}, \mathrm{GM}$ & 37 & $\mathrm{FR}, \mathrm{DF}, \mathrm{BR}$ & CA & 11 & $\mathrm{DB}, \mathrm{FR}$ & VTA \\
\hline $\begin{array}{c}\text { PR-14 } \\
\text { (A-12, A-13) }\end{array}$ & SX & N10W & $60^{\circ} \mathrm{W}$ & -- & Normal & 5.0 & SFG, GM & -- & $\mathrm{FR}, \mathrm{DF}, \mathrm{BR}$ & $\mathrm{CA}$ & -- & -- & VTA \\
\hline $\begin{array}{l}\text { PR-21 } \\
\text { (A-14) }\end{array}$ & $s x$ & $\mathrm{~N} 42 \mathrm{E}$ & $73^{\circ} \mathrm{SE}$ & -- & Normal & 1.3 & SFG & $>9$ & $\mathrm{FR}, \mathrm{DF}$ & $\mathrm{CA}$ & -- & -- & VTA \\
\hline $\begin{array}{l}\text { PR-31 } \\
\text { (A-15) }\end{array}$ & $s x$ & N15E & $80^{\circ} \mathrm{NW}$ & -- & Normal & 1.0 & $F G$ & 64 & FR, DF, BR & CA & 18 & DB & VTA \\
\hline $\begin{array}{c}\text { PR-33 } \\
(\mathrm{A}-16, \mathrm{~A}-17)\end{array}$ & sX & $\sim N$ & $\sim 80^{\circ} \mathrm{W}$ & -- & Normal & 1.0 & -- & 30 & FR, DF, BR & $\mathrm{CA}$ & -- & -- & $\mathrm{CA}$ \\
\hline $\begin{array}{c}\text { PR-65 } \\
(\mathrm{A}-18, \mathrm{~A}-19)\end{array}$ & sx & N65E & $\begin{array}{l}\sim 75^{\circ} \\
\mathrm{NW}\end{array}$ & -- & -- & 1.3 & $\mathrm{GM}, \mathrm{BR}$ & 4 & FR, SF, DF(?) & $\mathrm{CA}$ & 30 & BR, Shearing & $\mathrm{CA}$ \\
\hline
\end{tabular}


Table 3-1

Summary of Fault Zone Characteristics (continued)

\begin{tabular}{|c|c|c|c|c|c|c|c|c|c|c|c|c|c|}
\hline \multirow{4}{*}{$\begin{array}{c}\text { Fault } \\
\text { Station } \\
\text { (Figure No.) }\end{array}$} & \multirow{4}{*}{$\begin{array}{l}\text { Data } \\
\text { Type }^{\text {a }}\end{array}$} & \multirow{3}{*}{\multicolumn{4}{|c|}{ Fault Orientation and Offset }} & \multicolumn{8}{|c|}{ Architectural Components } \\
\hline & & & & & & \multirow{2}{*}{\multicolumn{2}{|c|}{ Fault Core }} & \multicolumn{6}{|c|}{ Damage Zone } \\
\hline & & & & & & & & \multicolumn{3}{|c|}{ Footwall } & \multicolumn{3}{|c|}{ Hanging Wall } \\
\hline & & Strike & Dip & $\begin{array}{l}\text { Offset } \\
\text { (feet) }\end{array}$ & $\begin{array}{l}\text { Slip } \\
\text { Sense }\end{array}$ & $\begin{array}{l}\text { Width } \\
\text { (feet) }\end{array}$ & Composition $^{b}$ & $\begin{array}{l}\text { Width } \\
\text { (feet) }\end{array}$ & $\begin{array}{l}\text { Permeability } \\
\text { Structures }\end{array}$ & $\mathrm{HGU}^{\mathrm{d}}$ & $\begin{array}{l}\text { Width } \\
\text { (feet) }\end{array}$ & $\begin{array}{l}\text { Permeability } \\
\text { Structures }\end{array}$ & HGU d \\
\hline $\begin{array}{l}\text { TP-100 } \\
\text { (A-20) }\end{array}$ & SX & N30E & $65^{\circ} \mathrm{SE}$ & $<50$ & Normal & $<1 \mathrm{~cm}$ & GM & 7 & SF, DB & VTA & -- & FR, DB & VTA \\
\hline $\begin{array}{l}\text { TP-101 } \\
(\mathrm{A}-21)\end{array}$ & SX & N55E & NW & 20 & Normal & $<<20$ & -- & -- & FR & WTA & 30 & FR & WTA \\
\hline $\begin{array}{l}\text { TP-102 } \\
(\mathrm{A}-22)\end{array}$ & SX & N55E & NW & 20 & Normal & -- & -- & -- & FR & VTA & -- & FR & VTA \\
\hline $\begin{array}{c}\text { TS-4 } \\
\text { (A-23) }\end{array}$ & sX & $\begin{array}{l}\text { N22- } \\
38 \mathrm{E}\end{array}$ & $75^{\circ} \mathrm{NW}$ & -- & Normal & -- & FG & -- & -- & $\mathrm{CCU}$ & $>10$ & SF & TCU \\
\hline $\begin{array}{c}\text { U1a } \\
(\mathrm{A}-24)\end{array}$ & TX & NE & $\begin{array}{l}70^{\circ}- \\
80^{\circ} \\
\mathrm{NW}\end{array}$ & $>12$ & Normal & 0.4 & GM, FG & $\geq 1.5$ & SF & AA & $\geq 1.5$ & SF & AA \\
\hline $\begin{array}{c}\text { N-GSD X-Cut } \\
(A-25)\end{array}$ & TX & N25W & $68^{\circ} \mathrm{W}$ & $>20$ & Normal & $\begin{array}{l}<2.5 \\
\mathrm{~cm}\end{array}$ & -- & $>6$ & FR & TCU & 1 & SF & TCU \\
\hline $\begin{array}{l}\text { N-10-A } \\
(A-26)\end{array}$ & $T X$ & N25E & $68^{\circ} \mathrm{W}$ & 1.2 & Normal & $<1 \mathrm{~cm}$ & -- & 0 & No damage & TCU & 0 & No damage & TCU \\
\hline $\begin{array}{c}\mathrm{N}-21 \mathrm{BP}-2 \\
(\mathrm{~A}-27)\end{array}$ & TX & $\begin{array}{l}\mathrm{N} 15- \\
25 \mathrm{~W}\end{array}$ & $65^{\circ} \mathrm{W}$ & $>20$ & Normal & $<0.5$ & FG & 0 & No damage & TCU & 0 & No damage & TCU \\
\hline $\begin{array}{c}N-17 B P \\
(A-28)\end{array}$ & TX & N30W & $84^{\circ} \mathrm{E}$ & $2-3$ & Normal & -- & -- & 0 & No damage & TCU & 0 & No damage & TCU \\
\hline $\begin{array}{c}\mathrm{N}-21 \mathrm{LOS}-1 \\
(\mathrm{~A}-29)\end{array}$ & $T X$ & $\begin{array}{l}\text { N15- } \\
25 \mathrm{~W}\end{array}$ & $\begin{array}{l}75^{\circ}- \\
80^{\circ} \mathrm{E}\end{array}$ & 3 & Normal & $<1 \mathrm{~cm}$ & -- & $>5.5$ & $\mathrm{FR}, \mathrm{SF}$ & TCU & 4 & $\mathrm{FR}, \mathrm{SF}$ & TCU \\
\hline $\begin{array}{c}\mathrm{N}-21 \mathrm{LOS}-2 \\
(\mathrm{~A}-30)\end{array}$ & $T X$ & $\begin{array}{l}\text { N15- } \\
25 \mathrm{~W}\end{array}$ & $75^{\circ}$ & 1 & Normal & $<1 \mathrm{~cm}$ & GM & 0 & No damage & TCU & 0 & No damage & TCU \\
\hline
\end{tabular}


Table 3-1

Summary of Fault Zone Characteristics (continued)

\begin{tabular}{|c|c|c|c|c|c|c|c|c|c|c|c|c|c|}
\hline \multirow{4}{*}{$\begin{array}{c}\text { Fault } \\
\text { Station } \\
\text { (Figure No.) }\end{array}$} & \multirow{4}{*}{$\begin{array}{l}\text { Data } \\
\text { Type }^{a}\end{array}$} & \multirow{3}{*}{\multicolumn{4}{|c|}{ Fault Orientation and Offset }} & \multicolumn{8}{|c|}{ Architectural Components } \\
\hline & & & & & & \multirow{2}{*}{\multicolumn{2}{|c|}{ Fault Core }} & \multicolumn{6}{|c|}{ Damage Zone } \\
\hline & & & & & & & & \multicolumn{3}{|c|}{ Footwall } & \multicolumn{3}{|c|}{ Hanging Wall } \\
\hline & & Strike & Dip & $\begin{array}{c}\text { Offset } \\
\text { (feet) }\end{array}$ & $\begin{array}{l}\text { Slip } \\
\text { Sense }\end{array}$ & $\begin{array}{l}\text { Width } \\
\text { (feet) }\end{array}$ & Composition ${ }^{b}$ & $\begin{array}{l}\text { Width } \\
\text { (feet) }\end{array}$ & $\begin{array}{l}\text { Permeability } \\
\text { Structures }^{c}\end{array}$ & $\mathrm{HGU}^{\mathrm{d}}$ & $\begin{array}{c}\text { Width } \\
\text { (feet) }\end{array}$ & $\begin{array}{l}\text { Permeability } \\
\text { Structures }^{c}\end{array}$ & HGU \\
\hline $\begin{array}{c}\mathrm{N}-22 \mathrm{BP} \\
(\mathrm{A}-31)\end{array}$ & $\mathrm{TX}$ & N50W & $78^{\circ} \mathrm{W}$ & 0.7 & Normal & $<1 \mathrm{~cm}$ & GM & 0 & No damage & TCU & 0 & No damage & $\mathrm{TCU}$ \\
\hline $\begin{array}{c}\mathrm{N}-24 \mathrm{BP} \\
(\mathrm{A}-32)\end{array}$ & TX & $\mathrm{N} 45 \mathrm{~W}$ & $70^{\circ} \mathrm{SW}$ & 16 & Normal & $<1 \mathrm{~cm}$ & GM & -- & -- & TCU & 0 & No damage & TCU \\
\hline $\begin{array}{l}\mathrm{T}-002 \\
(\mathrm{~A}-33)\end{array}$ & $\mathrm{TX}$ & N17E & $62^{\circ} \mathrm{NW}$ & 1.5 & Normal & -- & -- & -- & $\mathrm{FR}$ & TCU & -- & $\mathrm{FR}$ & TCU \\
\hline $\begin{array}{l}\mathrm{T}-003 \\
(\mathrm{~A}-34)\end{array}$ & TX & N15E & $73^{\circ} \mathrm{W}$ & 1.0 & Normal & -- & -- & -- & $\mathrm{FR}$ & TCU & -- & $\mathrm{FR}$ & TCU \\
\hline $\begin{array}{c}\text { UE-6d\#2 - } \\
1016.7 \\
(\mathrm{~A}-35)\end{array}$ & $\mathrm{VCH}$ & -- & $65^{\circ}$ & -- & Normal & 0.2 & $\mathrm{GM}, \mathrm{FG}$ & $7^{*}$ & DB & VTA & $2^{*}$ & FR & VTA \\
\hline $\begin{array}{c}\text { UE-6d\#2 - } \\
1049.7\end{array}$ & $\mathrm{VCH}$ & -- & $65^{\circ}$ & -- & Normal & 0.5 & SFG & $10^{*}$ & $\mathrm{FR}$ & TCU & $1^{*}$ & DB & VTA \\
\hline $\begin{array}{c}\text { UE-7f-2321 } \\
(A-36)\end{array}$ & $\mathrm{VCH}$ & -- & $70^{\circ}$ & 0.2 & Normal & $<0.1$ & -- & -- & -- & $\mathrm{TCU}$ & -- & -- & TCU \\
\hline $\begin{array}{l}\text { U12e.14 } \\
\text { UG3-669.5 }\end{array}$ & $\mathrm{HCH}$ & -- & -- & $<10$ & Normal & $<0.1$ & SP & 0 & -- & TCU & 0 & -- & TCU \\
\hline $\begin{array}{l}\text { U12T.03 } \\
\text { UG1-2116 }\end{array}$ & $\mathrm{HCH}$ & \multicolumn{12}{|c|}{$\begin{array}{l}\text { Three small ( }<2 \mathrm{~cm} \text { of offset) slickensided fault planes }<5 \mathrm{~mm} \text { wide observed within TCU from 2,110 to } 2,123 \mathrm{ft} \text {. Sparse fractures } \\
\text { with isolated apertures }<5 \mathrm{~mm} \text { are present from } 2,100 \text { to } 2,150 \mathrm{ft} \text {. }\end{array}$} \\
\hline $\begin{array}{c}\text { U12T.03 } \\
\text { UG1-2628 } \\
(\mathrm{A}-37, \mathrm{~A}-38)\end{array}$ & $\mathrm{HCH}$ & \multicolumn{12}{|c|}{ Zone of multiple striated slip planes, broken core, and sparse fractures with rare isolated aperture within TCU from 2,610 to 2,645 ft. } \\
\hline $\begin{array}{c}\text { U12T.03 } \\
\text { UG1-2735 } \\
\text { (A-39) }\end{array}$ & $\mathrm{HCH}$ & -- & -- & $>100$ & Normal & -- & -- & $<10$ & -- & TCU & $<10$ & -- & TCU \\
\hline
\end{tabular}


Table 3-1

Summary of Fault Zone Characteristics (continued)

\begin{tabular}{|c|c|c|c|c|c|c|c|c|c|c|c|c|c|}
\hline \multirow{4}{*}{$\begin{array}{c}\text { Fault } \\
\text { Station } \\
\text { (Figure No.) }\end{array}$} & \multirow{4}{*}{$\begin{array}{l}\text { Data } \\
\text { Type a }\end{array}$} & \multirow{3}{*}{\multicolumn{4}{|c|}{ Fault Orientation and Offset }} & \multicolumn{8}{|c|}{ Architectural Components } \\
\hline & & & & & & \multirow{2}{*}{\multicolumn{2}{|c|}{ Fault Core }} & \multicolumn{6}{|c|}{ Damage Zone } \\
\hline & & & & & & & & \multicolumn{3}{|c|}{ Footwall } & \multicolumn{3}{|c|}{ Hanging Wall } \\
\hline & & Strike & Dip & $\begin{array}{l}\text { Offset } \\
\text { (feet) }\end{array}$ & $\begin{array}{l}\text { Slip } \\
\text { Sense }\end{array}$ & $\begin{array}{l}\text { Width } \\
\text { (feet) }\end{array}$ & Composition $^{b}$ & $\begin{array}{l}\text { Width } \\
\text { (feet) }\end{array}$ & $\begin{array}{l}\text { Permeability } \\
\text { Structures }\end{array}$ & $H G U^{d}$ & $\begin{array}{l}\text { Width } \\
\text { (feet) }\end{array}$ & $\begin{array}{l}\text { Permeability } \\
\text { Structures }\end{array}$ & $\mathrm{HGU}^{\mathrm{d}}$ \\
\hline $\begin{array}{c}\text { U-3mL-2940 } \\
(\mathrm{A}-40)\end{array}$ & $\mathrm{DHC}$ & N10E & SE & 6 & Normal & $<0.5$ & -- & -- & $\begin{array}{l}\text { Minimal } \\
\text { damage }\end{array}$ & TCU & -- & $\begin{array}{l}\text { Minimal } \\
\text { damage }\end{array}$ & TCU \\
\hline $\begin{array}{c}\text { U-7by-1710 } \\
(A-41)\end{array}$ & $\mathrm{DHC}$ & N35W & SW & 0.5 & Normal & $<1 \mathrm{~cm}$ & -- & -- & $\begin{array}{l}\text { Minimal } \\
\text { damage }\end{array}$ & TCU & -- & $\begin{array}{l}\text { Minimal } \\
\text { damage }\end{array}$ & TCU \\
\hline
\end{tabular}

\section{$\underline{\text { Notes }}$}

a $S X=$ Surface exposure $T X=$ Tunnel exposure $\mathrm{VCH}=$ Vertical core hole $\mathrm{HCH}=$ Horizontal core hole $\mathrm{DHC}=$ Down-hole camera

b $F G=$ fault gouge

$\mathrm{GM}=$ granulated material

$\mathrm{SP}=$ slip plane

$\mathrm{BR}=$ breccia

SFG = silicified fault gouge

c $\mathrm{FR}=$ fracture

$\mathrm{SF}=$ smaller-scale fault

$\mathrm{BR}=$ breccia

$\mathrm{DB}=$ deformation band

DF = drag fold d $A A=$ alluvial aquifer

VTA = vitric-tuff aquifer

WTA = welded-tuff aquifer

TCU = tuff confining unit

$\mathrm{CA}=$ carbonate aquifer

$\mathrm{CCU}=$ clastic confining unit

-- Unknown or not applicable

* Calculated width parallel to fault 
The composition of fault core material observed in fault zones at the NTS during this study included mainly granulated sand-sized material and very fine-grained, clayey fault gouge. Breccia was observed at one location. Although breccia is commonly reported as fault core material in other studies (e.g, Sweetkind and Drake, 2007), most breccia observed in this study appeared to be associated with damage zones (see discussion below in Section 3.1.2). The poor exposure of fault cores at the NTS probably reflects the poorly consolidated nature of most fault core material. However, in several locations hard, dense silicified fault gouge was observed that in places formed conspicuous dike-like exposures (Figures A-12 through A-14). Fault cores were commonly observed to be bounded by slip surfaces that in some places formed conspicuous scarps in outcrop, particularly in the more consolidated units such as carbonate (Figures A-11. and A-15). These slip surfaces commonly separate breccia and shattered rock of the damage zone from the granulated and clayey gouge of the core zone. Consistent with other studies (Caine et al., 1996; Evans et al., 1997), the transition from fault core to damage zone was observed to be abrupt.

\subsubsection{Damage Zones}

Damage zones observed in this study were generally better exposed than fault core zones, particularly within the stronger and more consolidated units, but surface exposures were still mostly insufficient to conduct detailed quantitative analysis. Thus, caution must be exercised to avoid over-interpretation of observations. It is important to note, however, that damage zone characteristics of NTS fault zones are generally consistent with damage zone characteristics reported in other studies.

Fault-related damage was observed to be much more extensive in the stronger, more consolidated units such as welded tuff and carbonate than in weaker and less consolidated rocks such as alluvium and unaltered nonwelded tuff. Damage observed in the more consolidated rocks typically consisted of brecciation and shattering adjacent to the fault core, grading to highly fractured rock. The intensity of fracturing decreased outward toward the protolith (Figure A-21). Fractures were mostly open, and secondary fracture-filling mineralization was rarely observed in surface exposures. Bedding was commonly deformed by drag folding (Figure A-13B) Damage zone breccia typically formed relatively thin, well consolidated zones immediately adjacent to the fault core. Polished and grooved fault planes bounding the fault core were commonly developed on the damage-zone breccias, forming conspicuous surface scarps (Figures A-2 and A-15). Fault-related damage in weaker rock units, such as alluvium and vitric nonwelded tuff, was observed to be negligible in surface exposures and core samples. In 
these weaker rocks damage was characterized mainly by the presence of deformation bands and small-scale faults; fractures and breccia were generally absent (Figures A-20 and A-24).

The widest damage zone observed was $19.5 \mathrm{~m}$ (64 ft) within carbonate rocks, in the footwall of a normal fault in the Halfpint Range (Figure A-15). The width of the damage zone in the adjacent

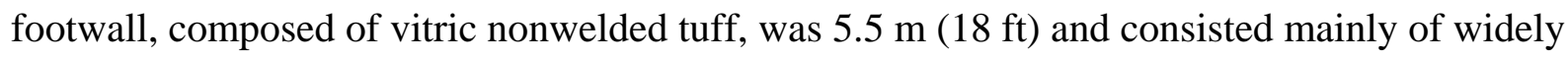
spaced deformation bands.

\subsection{Fault Characteristics in Hydrogeologic Units}

Fault zone characteristics, particularly those associated with damage zones, were observed to vary according to HGU. This is not surprising since lithology is a major component of HGU designations, and, as discussed in Section 1.2.3, fault-related deformation evolves differently in different rock types (NRC, 1996). Faults were observed in five of the ten NTS HGUs, and their fault zone characteristics are described in the following sections.

\subsubsection{Alluvial Aquifer}

The only information on the nature of faults and associated permeability structures within AAs at the NTS came from faults intersected by mining within the U1a Complex beneath Yucca Flat. Faults observed in the complex have fault core zones that are typically less than $14 \mathrm{~cm}$ (5.5 in.) wide (but may be up to $30 \mathrm{~cm}$ [12 in.] wide), rarely exhibit open aperture, and are typically filled with sandy granulated material and very fine-grained gouge (Figure A-24), X-ray diffraction analysis of a sample of fine-grained fault gouge showed only slightly higher clay content than the surrounding alluvium (Drellack et al., 1989). Secondary mineralization, such as calcium carbonate, is rare. Individual fault planes within fault core zones often form wavy or undulating surfaces, and slickensides are common. Flat pebbles, presumably deposited nearly horizontally, are sometimes observed to be rotated parallel to the fault.

Damage associated with faults in the U1a Complex is negligible, and is typically in the form of small-displacement faults, anastomosing fault splays, closed fractures, and disturbed bedding (Figure A-24), Open aperture associated with these damage-zone features is rare. Damage

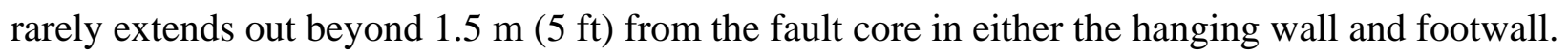

Based on observations of faults intersected in the U1a Complex, small to medium-size faults in alluvium probably have little effect on groundwater flow. Any effect would probably tend to inhibit flow, particularly perpendicular to the strike of the faults, due to reduction in porosity and permeability within fault cores by porosity collapse, grain size reduction, and development of 
very fine-grained gouge. The typically weak and poorly consolidated nature of alluvium probably precludes extensive development of open fractures in damage zones. Consequently, fault zones associated with larger faults within alluvium, such as the Yucca Fault, may not form zones of significantly enhanced permeability, but instead may tend to behave as leaky barriers to groundwater flow, particularly in directions normal to the strike of the fault.

\subsubsection{Vitric-Tuff Aquifer}

Faults within VTA rocks were observed in numerous outcrops and a single vertical core hole in Yucca Flat. Fault characteristics observed in VTAs at the NTS vary according to the strength and degree of consolidation of the rock. Typical VTAs, consisting of porous and weakly consolidated vitric nonwelded tuff, have fault zone characteristics similar to those observed in nonwelded tuffs at Yucca Mountain and northern New Mexico (Wilson et al., 2003) and in porous and weakly consolidated sediments (Rawling and Goodwin, 2003; Rawling et al., 2001; Antonellini and Aydin, 1994; 1995). Fault core zones within typical VTA rocks at the NTS were observed to be very narrow zones, typically less than $15 \mathrm{~cm}$ (6 in.) wide and consisting of granulated material and clayey fault gouge (Figures A-1 and A-35). Fault-related damage was typically negligible and characterized by the presence of relatively widely spaced deformation bands that commonly strike parallel to the fault (Figures A-1 and A-20; fractures were generally

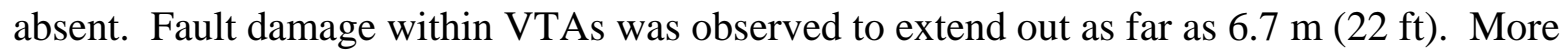
consolidated VTA rocks, such as those with partially silicified or devitrified intervals, however, can have damage zones consisting of enhanced fracturing. One exposure of partially silicified VTA in the hanging wall of the Plutonium Valley Fault showed rather intense shattering and drag folding immediately adjacent to the fault (Figure A-8).

Similar to AA, another porous and poorly consolidated HGU, faults and associated permeability structures likely have a minimal effect on groundwater flow through VTA because of the narrow fault cores and minimal damage observed in damage zones. Any effect of faults within typical poorly consolidated VTAs will most likely result in a reduction in permeability relative to the protolith due to the presence of deformation bands in damage zones and clayey fault gouge within fault cores. Permeability reduction caused by faulting within VTAs is probably anisotropic, with the most reduction occurring in a direction perpendicular to the fault due to the presence of the fault core and the tendency for deformation bands to strike parallel to the fault. Horizontal flow parallel to faults within damage zones in VTAs is probably minimally inhibited by fault-related structures. Vertical flow, however, may be somewhat inhibited because of the presence of deformation bands that strike parallel to the fault but dip in a direction opposite (i.e., antithetic) than that of the fault. 
Post-depositional alteration processes such as devitrification and silicification, which result in lithologic heterogeneity within VTAs, also result in heterogeneity of damage zone flow properties within VTAs if alteration occurred prior to faulting. These processes tend to increase the strength of VTA, which can result in the formation of fractures, and thus enhance the permeability within the damage zones of faults cutting altered portions of VTA.

\subsubsection{Welded-Tuff Aquifer}

Faults and associated permeability structures likely have significant and important impacts with regard to groundwater flow properties within WTAs at the NTS. As in most strong and well consolidated rock units, fractures within WTAs are the main permeability structures controlling aquifer properties, and the intensity of fracturing was observed to increase in the damage zones of faults cutting WTAs at the NTS. Damage zones within WTAs are characterized by enhanced fracturing, with the intensity of fracturing increasing towards the fault (Figures A-5 and A-21). Shattered and brecciated material was observed adjacent to the fault core in several exposures (Figures A-2 and A-21. No drag folding was observed within WTA damage zones. The width of fault damage zones in WTA was observed to extend out $9.1 \mathrm{~m}(30 \mathrm{ft})$.

Although poorly exposed, fault core zones observed associated with WTAs at the NTS are relatively narrow zones, and compose only a small percentage of the total fault zone width. The poor exposure of fault cores suggests that fault core material is weakly consolidated, which is consistent with observations of highly granulated rock material and clayey fault gouge in other well consolidated HGUs (e.g., CA).

Damage zones within WTAs likely form zones of significantly enhanced permeability related to an increase in the abundance of open fractures. Fracture intensity, and consequently permeability enhancement, increases toward the fault core within the damage zone. Because fractures within damage zones tend to be oriented parallel to the fault, enhanced permeability is likely anisotropic, with greater permeability in a direction parallel to the fault in both horizontal and vertical directions. Permeability enhancement normal to the strike of faults within WTAs is probably less, due to both the paucity of fractures oriented normal to the fault and the barriertype properties of the fault core.

The presence of pre-existing (i.e., pre-faulting) well-developed cooling joints may limit the increase in fracture permeability within the damage zones of WTAs. These abundant discontinuities may accommodate the strain imparted by fault-related stresses, and thus reduce the amount of fault-related damage such as enhanced fracturing. The presence of well- 
developed cooling joints, however, likely results in enhanced permeability of WTAs, irrespective of enhanced fracturing related to faulting. Factors controlling the degree of development of cooling joints are poorly understood; thus, predicting where cooling joint development is greatest or most pronounced within WTAs is difficult and beyond the scope of this study.

\subsubsection{Tuff Confining Unit}

Faults in the TCU were observed in surface exposures, historical tunnel photos, and core holes, and down-hole camera data. Most fault cores were observed to be very thin, typically less than $15 \mathrm{~cm}$ (6 in.) wide. Many of the fault cores were associated with small-displacement faults

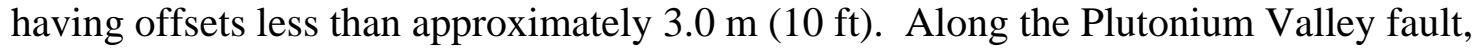
however, where offset is estimated to be $120 \mathrm{~m}$ (400 ft) and TCU occurs within the footwall only, the poorly exposed fault core may be up to $3 \mathrm{~m} \mathrm{(10} \mathrm{ft)} \mathrm{wide.} \mathrm{Sweetkind} \mathrm{and} \mathrm{Drake} \mathrm{(2007)}$ observed faults in zeolitic tuff at the NTS with fault cores less than $10 \mathrm{~cm}$ (4 in.) for faults with offsets between 3 and $25 \mathrm{~m}$ (10 and $82 \mathrm{ft}$ ). Fault cores were typically observed to be composed of granulated material and clayey gouge.

These data show that fault core zones within TCU at the NTS are narrow features typically composed of granulated protolith material and clayey fault gouge. The intensity of deformation within damage zones of TCU was observed to fall between that of VTA and WTA. This is most likely due to the strength and consolidation of TCU being generally greater than VTA and less than WTA. Like VTA, however, damage zone characteristics vary according to the strength and degree of consolidation of individual intervals. Stronger and more consolidated intervals, such as silicified beds, show a greater intensity and abundance of fractures. Because TCU consists mostly of rocks originally deposited as VTA but later altered mainly by zeolitization, fault zone characteristics within TCU will be dependent on the timing of fault movement relative to alteration. If faulting occurred prior to zeolitic alteration, then fault related damage will be negligible within TCU because the TCU would have inherited the fault zone characteristics of VTA.

Because the strength and consolidation of TCU is intermediate between that of the weakest and strongest HGUs, TCU damage zone characteristics will also tend to be intermediate, and include fractures and smaller scale faults. Although fracture development within TCU damage zones is observed to be significantly less than the that for the stronger HGUs like WTA, permeability enhancement may still be significant relative to typical TCU protolith. 


\subsubsection{Carbonate Aquifer}

Numerous exposures of faulted CA were studied, and all showed fault-related permeability features consistent with strong and well consolidated rock units. Most of the faults studied were basin-and-range normal faults, but one may represent an older reverse fault. Damage zone characteristics included enhanced fracture development, with fracture intensity increasing towards the fault core. Cemented breccia was common adjacent to the fault core, but most damage zone fractures were open, with little secondary mineralization observed. Surface scarps consisting of polished and grooved fault planes were observed developed on the breccia deposits (Figures A-11 and A-15). Drag folding was also common within the damage zones of CA. The width of damage zones in CA ranged from 1.2 to $20.0 \mathrm{~m}$ (4 to $64 \mathrm{ft}$ ), and averaged $10.1 \mathrm{~m}$ (33 ft).

Although rarely exposed, fault cores were observed to be relatively narrow zones, typically less

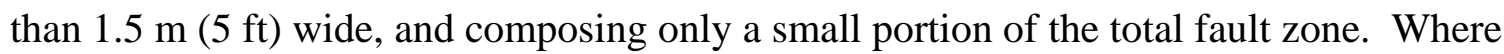
exposed, fault core material consisted of brecciated and granulated carbonate material (Figure A-19).

Fault zones within CA at the NTS likely create important zones of enhanced permeability. Permeability enhancement is the result of an increase in fracturing within the damage zones of faults cutting CA. Although fault cores likely form zones of low permeability, they are relatively narrow and thus probably have little overall influence on the permeability of fault zones within CA. However, the presence of the fault core and the tendency of fractures to strike parallel to the fault likely create anisotropy with regard to flow properties within CA fault zones. Flow properties are probably most enhanced in a direction parallel to the strike of the fault. Horizontal flow perpendicular to the strike of the fault is probably least enhanced due to the presence of the fault core material and the tendency for fractures to form parallel to the strike of the fault.

\subsubsection{Other HGUs}

Although no observations were made of faults in playa confining unit (PCU), clastic confining unit (CCU), granite confining unit (GCU), intra-caldera intrusive confining unit (IICU), or lavaflow aquifer (LFA), fault zone characteristics observed in the other HGUs can provide useful insights regarding possible fault zone characteristics in these four HGUs.

LFAs probably have fault zone characteristics very similar to WTAs since both consist of hard, dense, extrusive igneous rocks. Consequently, faults within LFAs will probably tend to have 
damage zones characterized by enhanced fracture development, resulting in zones of enhanced permeability relative to the protolith. Fault core zones are probably narrow, form only a small portion of the fault zone, and act as leaky barriers to groundwater flow directed perpendicular to the strike of the fault.

The fine-grained, soft, and weak nature of playa deposits (which are composed mainly of silt and clay) would suggest that faults within PCU probably do not form fracture-enhanced damage zones. Thus, fault zones within PCU probably do not form zones of enhanced permeability.

The CCU includes both fine- and coarse-grained siliciclastic sedimentary rocks. Fault zones within finer-grained CCUs (i.e., composed of Eleana Formation and Chainman Shale) that consist mostly of siltstone and shale probably create fault zones of only minimal enhancement because such lithologies tend to be poorly fractured. Faults, therefore, probably do not enhance significantly the permeability of fine-grained CCU. However, coarser-grained CCU, such as that consisting of Precambrian sandstone and quartzite, may develop fracture-enhanced damage zones. These rocks are typically highly cemented and consolidated, resulting in stronger and more consolidated units that would be expected to deform in a fashion similar to other strong and well consolidated HGUs like WTA and CA. Thus, fault zones within the coarser-grained CCUs likely form zones of fracture-enhanced permeability.

GCU, which is composed of igneous intrusive rocks such as granite, are also strong and well consolidated rocks. Thus, faults offsetting GCU likely form damage zones characterized initially (prior to any mineralization) by enhanced fracture development.

IICU, which is postulated to be composed of strong, well indurated rocks such as igneous intrusive rocks and/or highly intruded and altered basement rocks beneath calderas, would probably form damage zones characterized by enhanced fracture permeability. However, if these rocks are present, as modeled, deep beneath calderas, open conduits within them probably were filled rather quickly by secondary mineralization.

The role of fault zones within confining unit HGUs needs to be carefully considered. Although open fracture networks may be scarce within the protolith of TCU, GCU, IICU, and coarsergrained CCU, faults cutting these HGUs will likely form damage zones with enhanced fracture permeability. 


\subsection{Implications for Groundwater Flow Modeling}

Faults are complex, profound, and dominant geologic features at the NTS, so it is reasonable to assume that faults are also important, yet complex, hydrologic features. Comparing and contrasting observations of fault zones at the NTS with observations and data from other studies strongly suggests that faults at the NTS form discrete zones of enhanced fracture permeability within those HGUs susceptible to enhanced fracture development. However, fault zone flow properties vary in both space and time. Consequently, not all faults form zones of enhanced permeability, and permeability enhancement will vary along individual faults. Although many factors influence fault zone flow properties, most fault zone heterogeneity and flow property variability is the result four major factors:

1) Fault zone architecture (i.e., fault core and damage zones)

2) Rock type (i.e., HGU)

3) Age of faulting

4) Fault orientation

Based on these four factors, a simplified, first-approximation, conceptual model for the distribution of fault zone flow properties can be developed. All faults have fault zones with total fault zone width less than $100 \mathrm{~m}$ (300 ft). As a general guideline, larger faults with the most offset (e.g., the Yucca Fault) will have the maximum width. However, there is a poor correlation between amount of offset and fault zone width.

All fault zones are composed of a fault core and damage zones that typically impart a first-order heterogeneity and flow anisotropy within the fault zone itself. The fault core is a very narrow zone of low permeability that is best modeled as a barrier to flow along the fault and a leaky barrier to flow across the fault in all HGUs. Because fault cores are very narrow and compose only a small percentage of the total fault zone width, it may be difficult as well as unnecessary to represent actual fault cores in numerical models. The effect of fault cores may be accounted for by reducing permeability within the fault zone in a direction that is normal to the strike of the fault.

Damage zones will typically, but not always (depending on rock type [i.e., HGU]), enhance permeability within NTS fault zones compared to the protolith, due to the formation of additional fracture networks within damage zones. Because damage tends to increase towards the fault 
core, the highest permeability values within damage zones will tend to be adjacent to the fault core. In addition, because the dominant fracture network within damage zones includes fractures that strike parallel to the fault, especially within damage zones of normal faults, permeability enhancement within damage zones will typically be anisotropic, with greater enhancement in a direction parallel to the strike of the fault. In summary, fault zones at the NTS likely form zones of enhanced fracture permeability within most HGUs. Enhanced permeability will tend to be anisotropic, with greater permeability in a direction parallel to the strike of the fault.

Fault-related deformation varies according to rock type, which is generally synonymous with lithology. Because lithology is a major component in the delineation of NTS HGUs, fault zone characteristics vary with HGU. The stronger, more consolidated and rigid HGUs, such as WTA, LFA, CA, coarser-grained CCU, GCU, and IICU, will tend to develop damage zones characterized by enhanced fracture permeability. Damage zones within the weaker and least consolidated HGUs such as AA, PCU, and VTA, will tend to be characterized by deformation bands and smaller-scale faulting, and the general absence of fractures. Fault zones within these HGUs will tend not to result in enhanced permeability, and may actually reduce permeability relative to the protolith. Because the strength and consolidation of TCU is intermediate between that of the weaker and stronger HGUs, TCU damage zone characteristics will also tend to be intermediate, and include fractures and smaller scale faults. Although fracture development within TCU damage zones is observed to be significantly less than that for the stronger HGUs like WTA, permeability enhancement may still be significant relative to typical TCU protolith.

The age of faulting can have a significant effect on fault zone flow properties. Faults most likely to have fault zones with enhanced permeability in HGUs susceptible to enhanced fracture development (e.g., WTA, LFA, and CA) are the younger, most recently active faults. These faults are less likely to have pervasive secondary mineralization filling fault-zone fracture conduits, simply because there may not have been sufficient time for extensive secondary mineralization to occur since the latest fault movement and associated fracturing. Such faults include strike-slip faults and basin-and-range normal faults, particularly those faults in areas that have experienced the greatest amounts of extension, such as the eastern and southern portions of the NTS (Sawyer et al., 1994). Recent earthquake activity in Frenchman Flat and Rock Valley indicates active faulting in these areas.

Older faults such as the Belted Range and CP thrust faults and their associated imbricate faults, which formed more than 100 million years ago, may not have zones of significantly enhanced permeability due to secondary mineralization filling open fractures. This is observed rather 
spectacularly in core samples across the CP thrust fault in Well ER-6-2 that show very coarsely crystalline secondary calcite filling and lining fractures and cementing dolomite breccia (Figure 4-1). It was also observed in this study that calcite-filled fractures were much more abundant in carbonate rocks in the CP Hills, where they occur in the hanging wall of the CP thrust fault, than in carbonate rocks in the Halfpint Range east of Yucca Flat, which are interpreted to generally be un-thrusted (Cole et al., 1997).

Caldera faults are particularly profound structural features that accommodate catastrophic collapse of caldera floors. All caldera faults at the NTS are deeply buried and thus not available for direct observation. It is likely, however, that intense damage, including pervasive fracturing of adjacent wall rock, is associated with such large and rapid faulting. Evidence for the development of enhanced permeability zones associated with caldera faults includes the common occurrence of secondary mineralization and alteration associated with caldera margins (Lipman, 2000). Enhanced permeability is probably short-lived because secondary mineralization and alteration are likely rapid due to nearby sources of heat and secondary minerals from volcanic and magmatic processes active at the time of fault zone formation. Because calderas in the NTS vicinity are older than approximately 9 million years (Sawyer et al., 1994), it is likely that fault zones associated with caldera faults at the NTS tend to act more as barriers to groundwater flow than as conduits, due to secondary mineralization and alteration. Evidence for secondary mineralization and alteration associated with NTS calderas includes alteration mapped along the southwest margin of the Ammonia Tanks caldera (Lipman et al., 1966), secondary silica occurring in fault zones on Timber Mountain (Figure 4-2), and extensive alteration of rocks penetrated by drill hole UE-18t (Byers et al., 1981) drilled in the northeastern portion of the Timber Mountain caldera complex.

Field studies and experiments have shown that the most permeable fault zones are typically those associated with active faults oriented for failure in the current stress regime (Barton et al., 1995; Hickman et al., 1997). Ferrill et al. (1999) used slip and dilation tendency analysis to determine the most favorable fault orientations (i.e., strike and slip) for optimum fluid flow at Yucca Mountain. Studies on the current stress directions in the NTS vicinity indicate that the current horizontal minimum stress direction is $\mathrm{N} 50^{\circ}-65^{\circ} \mathrm{W}$ (Dockery, 1984; Stock et al., 1985; Minor, 1989). This would suggest that potentially active faults, such as normal faults in the eastern and southern portions of the NTS that are oriented $\mathrm{N} 25^{\circ}-40^{\circ} \mathrm{E}$ (i.e., perpendicular to the horizontal minimum stress direction), will tend to have fault zones with the most enhanced permeability. Since faults are rarely perfectly linear, fault zone permeability will tend to vary locally along the fault according to the local orientation of the fault. 


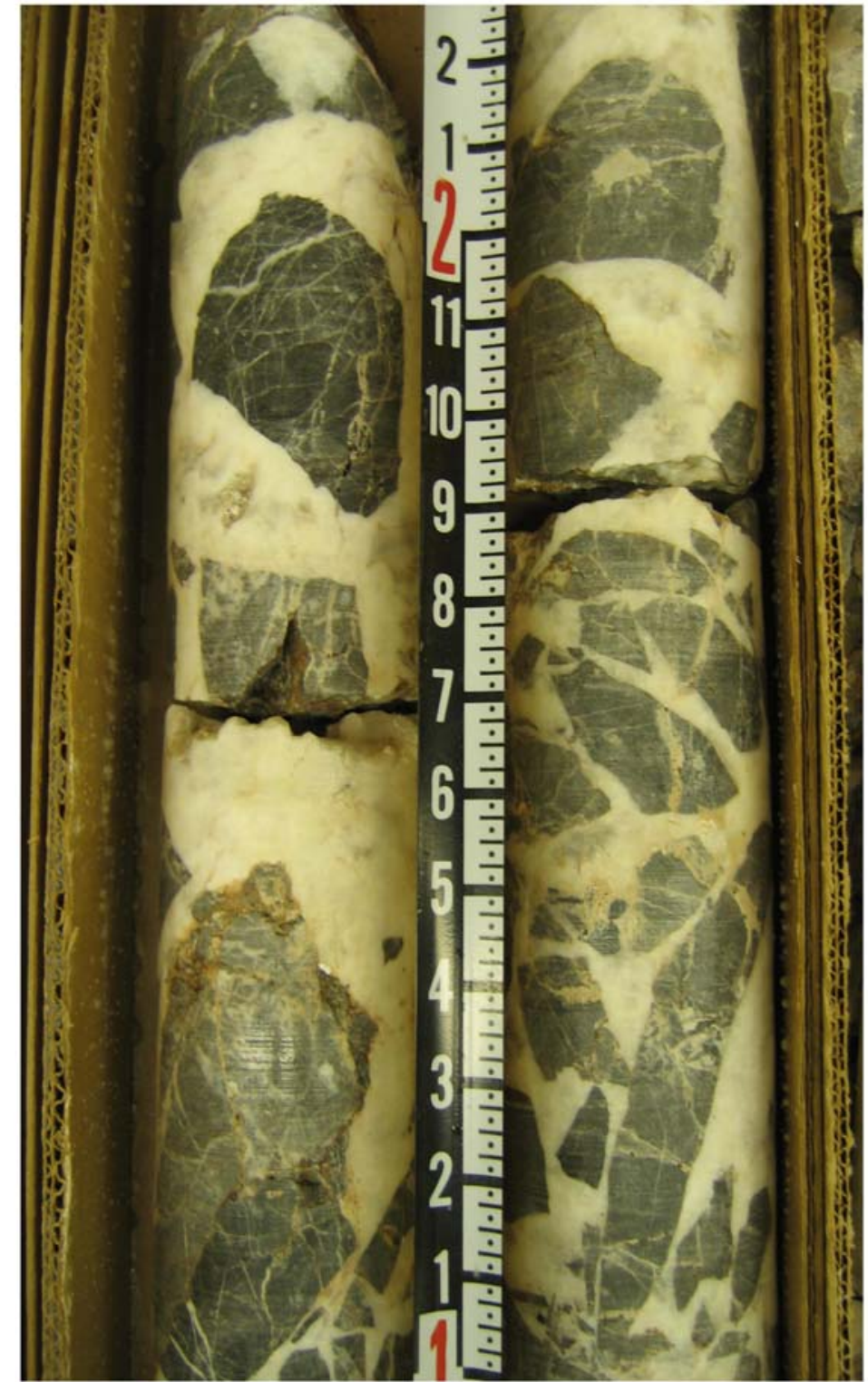

Breccia consisting of dolomite clasts within a coarsely crystalline calcite matrix. Tape measure is marked in inches.

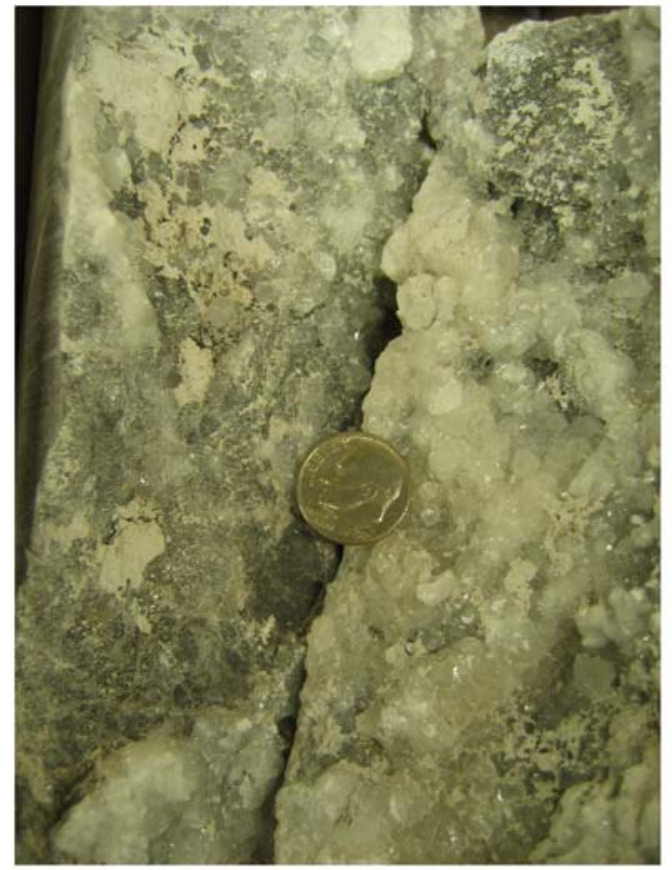

Secondary calcite crystals lining fracture in dolomite.

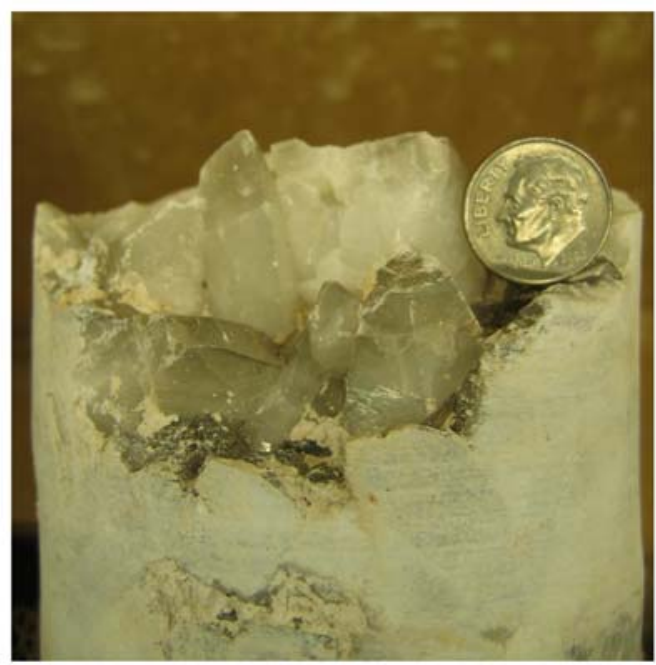

Large secondary calcite crystals lining opening in dolomite.

Figure 4-1

Secondary Calcite in Core Samples from the Hanging Wall of the CP Thrust Fault in UGTA Well ER-6-2 


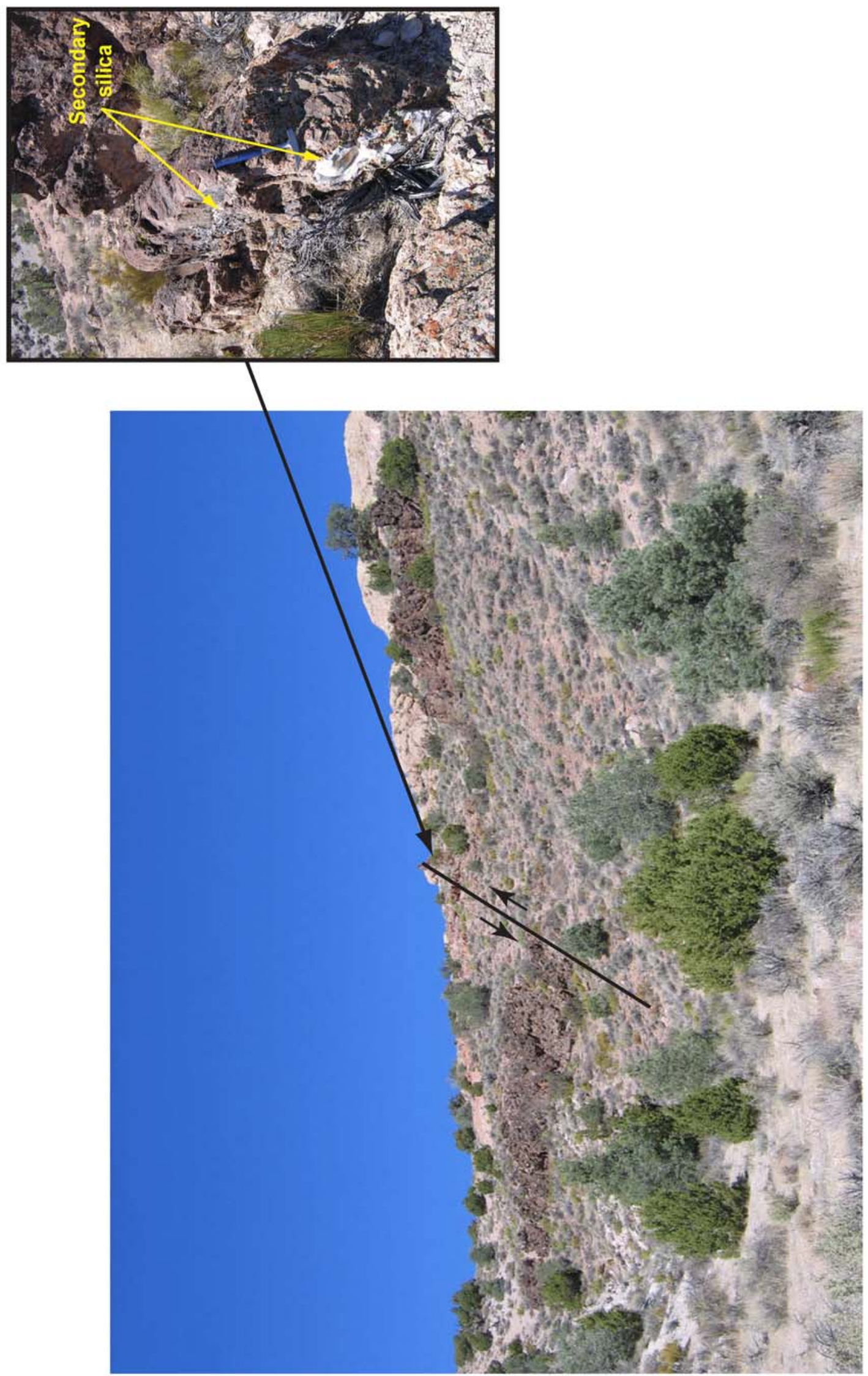

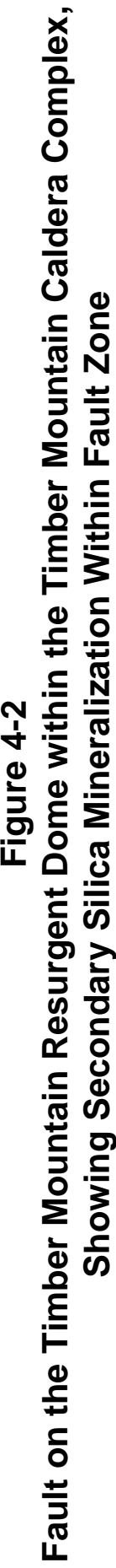


The region between overlapping en echelon faults can be regions of enhanced fracture permeability (NRC, 1996), and in effect create linkages between the damage zones of individual faults. Thus, continuous zones of fault-related enhanced permeability may extend laterally for long distances as damage zones of separate faults are linked together where they overlap.

It should be remembered that UGTA CAU-scale HFMs are geologically simplified and, thus, include only a small portion of the faults present. These are typically the larger normal faults. Therefore, portions of HSUs between model faults likely have, in reality, many more faults, albeit smaller, with associated fault zones not included in the model. The effect of the faults not captured in the HFMs on the flow properties of HSUs should be considered during flow modeling and HSU parameterization. 


\subsection{Summary of Conclusions}

Observations of NTS faults from a variety of sources indicate that fault characteristics, including fault zone permeability structures, are similar to characteristics of faults studied in other regions and geologic settings. Fault zones at the NTS are complex structural and hydrologic features that likely vary in both space and time. Although many factors influence fault zone flow properties, most fault zone heterogeneity and flow property variability can be attributed to four major factors:

1) Fault zone architecture (i.e., fault core and damage zones)

2) Rock type (i.e., HGU)

3) Age of faulting

4) Fault orientation

Based on these four factors, a simplified, first approximation, conceptual model for the distribution of fault zone flow properties associated with NTS faults can be developed to provide general guidance during construction, parameterization, and evaluation of groundwater-flow and contaminant-transport models.

\subsection{General NTS Fault Characteristics}

Faults at the NTS form relatively narrow (less than $100 \mathrm{~m}$ [300 ft]), yet discrete, tabular fault zones that have flow properties that vary from fault to fault as well as along individual faults. The most recently active faults, such as strike-slip faults and normal faults in the more extended terrains of the eastern and southern portions of the NTS, probably form the most permeable fault zones, but only where they cut the stronger and more consolidated HGUs such as WTA, LFA, CA, Precambrian CCU, IICU, and GCU. Where these faults intersect TCU, they likely form zones of enhanced fracture permeability significantly less than those formed in the stronger HGUs, but possibly still significantly enhanced relative to TCU protolith. Within weaker HGUs, such as AA, PCU, and VTA, these faults will typically not form zones of enhanced permeability, and may actually form zones of slightly reduced permeability relative to the protolith. Enhancement of fault zone permeability is generally controlled by fractures, and will tend to be anisotropic, with greater permeability values parallel to the strike of the fault. Fault segments oriented $\mathrm{N} 25^{\circ}-40^{\circ} \mathrm{E}$ will likely have the greatest amounts of permeability enhancement. Zones of enhanced fracturing between overlapping fault segments can effectively link fault zones and create long continuous zones of enhanced permeability. 
Fault zones associated with older faults, such as the Belted Range and CP thrust faults, are probably not currently zones of significantly enhanced permeability within any HGU due to secondary mineralization that has filled most of the originally open fractures. Similarly, caldera faults are likely zones of secondary mineralization and alteration, and thus are also not currently zones of enhanced permeability within any HGU, and in fact may tend to act as barriers to groundwater flow.

\subsection{Suggestions for Future Work}

The scope of this study was generally limited to gathering observational data on fault zones to help non-geologists associated with the UGTA project gain a better understanding of the physical characteristics of NTS faults that may affect groundwater flow. However, several reviewers of an earlier draft of this report made valuable suggestions for additional work on this subject. To acknowledge these suggestions and provide "food for thought" for potential future work on this important yet complex subject, the reviewers' suggestions are summarized below.

Suggestions relating to fault observations included expanding on the current study to include faults from Pahute Mesa, if possible; adding observations of surface expressions of the Yucca Fault; and including more information on the use of Core Index and borehole image logs as interpretive tools. Suggestions were also made to explore the differences between the surface and subsurface expressions of faults, to include more discussion of faults and stress fields, and to address data transferability.

Other comments suggested future studies to answer questions related to the modeling of faults in the UGTA flow and transport models, especially about how faults should be represented and parameterized in flow models. Two important questions are: How can fault observations and properties be scaled to the grid node sizes used in the UGTA models? How can geologic observations of fault properties be used to assign hydraulic conductivity values? These and other topics could form the basis for interdisciplinary discussions and investigations to more fully integrate geologic studies, hydraulic data, and flow and transport modeling.

Some specific suggestions for future work that could help fill the gap between geologic observations and the information used in groundwater models to represent fault properties are listed below: 
- Explore how flow-field effects of smaller-scale faults can be quantified. Currently, only a few of the larger NTS area faults are known to impact flow fields within UGTA flow models. However, the effects of the more numerous smaller faults are poorly known and very difficult to measure.

- Explore whether the concept of geologic structural domains could be used as an approach for assigning fault properties.

- Examine how differing hydraulic conductivity values away from and within faults could provide a systematic way of assigning fault permeability effects.

- Explore whether fractures related to faulting differ in their potential flow effects from cooling joints found in WTAs. 
This page intentionally left blank. 


\subsection{References}

Antonellini, M. A., and A. Aydin, 1994. "Effect of Faulting on Fluid Flow in Porous Sandstone: Petrophysical Properties.” American Association of Petroleum Geologists Bulletin, vol. 78, pp. 355-377.

Antonellini, M. A., and A. Aydin, 1995. "Effect of Faulting on Fluid Flow in Porous Sandstone: Geometry and Spatial Distribution.” American Association of Petroleum Geologists Bulletin, vol. 79, pp. 642-671.

Asquith, G. B., and D. Krygowski, 2004. Basic Well Log Analysis, Second Edition. Tulsa, OK: American Association of Petroleum Geologists Methods in Exploration Series No. 16, 244 p.

Aydin, A., and Y. Eyal, 2002. “Anatomy of a Normal Fault with Shale Smear: Implications for Fault Seal.” American Association of Petroleum Geologists Bulletin, vol. 86, no. 8, pp. 1,367-1,381.

Barton, C. A., M. D. Zoback, and D. Moos, 1995. "Fluid Flow along Potentially Active Faults in Crystalline Rock.” Geology, vol. 23, no. 8, pp. 683-686.

Bechtel Nevada, 2005. A Hydrostratigraphic Model and Alternatives for the Groundwater Flow and Contaminant Transport Model of Corrective Action Unit 98: Frenchman Flat, Clark, Lincoln, and Nye County, Nevada. DOE/NV/11718--1064. Las Vegas, NV.

Bechtel Nevada, 2006. A Hydrostratigraphic Model and Alternatives for the Groundwater Flow and Contaminant Transport Model of Corrective Action Unit 97: Yucca Flat-Climax Mine, Lincoln and Nye Counties, Nevada. DOE/NV/11718--1119. Las Vegas, NV.

Blenkinsop, T. G., 1989. “Thickness-Displacement Relationships for Deformation Zones: Discussion.” Journal of Structural Geology, vol. 11, no. 8, pp. 1,051-1,054.

BN, see Bechtel Nevada.

Burkhard, N. R., and R. D. McArthur, 1985. "Geologic and Geophysical Investigations of Mid Valley at the NTS.” In: Olsen, C. W., and M. L. Donohue, eds., Proceedings of the Third Symposium on Containment of Underground Nuclear Explosions, vol. 2, pp. 72-82. CONF-850953, Livermore, CA.

Byers, F. M., Jr., W. L. Hawkins, and D. C. Muller, 1981. Geology of Drill Hole UE18t and Area 18 Timber Mountain Caldera Moat, Nevada Test Site. U.S. Geological Survey Report USGS-474-312.

Caine, J. S., J. P. Evans, and C. B. Forster, 1996. "Fault Zone Architecture and Permeability Structure.” Geology, vol. 24, pp. 1,025-1,028. 
Caskey, S. J., and R. A. Schweickert, 1992. "Mesozoic Deformation in the Nevada Test Site and Vicinity: Implications for the Structural Framework of the Cordilleran Fold and Thrust Belt and Tertiary Extension North of Las Vegas.” Tectonics, vol. 11, no. 6, pp. 1,314-1,331.

Cole, J. C., and P. H. Cashman, 1999. Structural Relationships of Pre-Tertiary Rocks in the Nevada Test Site Region, Southern Nevada. U.S. Geological Survey Professional Paper 1607, 39 p. Denver, CO.

Cole, J. C., A. G. Harris, and R. R. Wahl, 1997. Subcrop Geologic Map of Pre-Tertiary Rocks in the Yucca Flat and Northern Frenchman Flat Areas, Nevada Test Site, Southern Nevada. U.S. Geological Survey Open-File Report 97-678, scale 1:48,000, 24 p. Denver, CO.

Dockery, H. A., 1984. Written Communication. Subject: "Rotation of Late Cenozoic Extensional Stresses, Yucca Flat Region, Nevada Test Site, Nevada.” Ph.D. Thesis, Rice University, Houston, TX. 77 p.

Drellack, S. L., Jr., P. H. Thompson, and C. J. Rayburn, 1989. Geology of the U-1a.01 Horizontal Drift Complex, Southwestern Yucca Flat, Nevada Test Site. Fenix \& Scisson of Nevada Geologic Report DOE/NV/10322-37, 69 p. Las Vegas, NV.

Ege, J. R., 1987. Core Index, a Numerical Core-Logging Procedure for Estimating Rock Quality. U.S. Geological Circular 954, 15 p. Denver, CO.

Evans, J. P., 1990. “Thickness-Displacement Relationships for Fault Zones.” Journal of Structural Geology, vol. 12, no. 8, pp. 1,061-1,065.

Evans, J. P., C. B. Forster, and J. V. Goddard, 1997. "Permeability of Fault-Related Rocks, and Implications for Hydraulic Structure of Fault Zones.” Journal of Structural Geology, vol. 19, no. 11, pp. 1,393-1,404.

Ferrill, D. A., J. Winterle, G. Wittmeyer, D. Sims, S. Colton, A. Armstrong, and A. P. Morris, 1999. "Stressed Rock Strains Groundwater at Yucca Mountain, Nevada." GSA Today, vol. 9, no. 5., pp. 1-8.

Fossen, H., and A. Bale, 2007. "Deformation Bands and Their Influence on Fluid Flow.” American Association of Petroleum Geologists, vol. 91, no. 12, pp. 1,685-1,700.

Goodwin, L. B., P. S. Mozley, J. C. Moore, and W. C. Haneberg, 1999. “Introduction.” In: Haneberg, W. C., P. S. Mozley, J. C. Moore, and L. B. Goodwin, eds., Faults and Subsurface Fluid Flow in the Shallow Crust. American Geophysical Union Geophysical Monograph 113, pp. 1-5.

Heynekamp, M. R., L. B. Goodwin, P. S. Mozley, and W. C. Haneberg, 1999. “Controls on Fault-Zone Architecture in Poorly Lithified Sediments, Rio Grande Rift, New Mexico: Implications for Fault-Zone Permeability and Fluid Flow.” In: Haneberg, W. C., P. S. Mozley, J. C. Moore, and L. B. Goodwin, eds., Faults and Subsurface Fluid Flow in the Shallow Crust: American Geophysical Union Geophysical Monograph 113, pp. 27-49. 
Hickman S. H., C. A. Barton, M. D. Zoback, R. Morin, J. Sass, and R. Benoit, 1997. "In-Situ Stress and Fracture Permeability along the Stillwater Fault Zone, Dixie Valley, Nevada.” International Journal of Rock Mechanics and Mineral Science, Paper 126, vol. 34, no. 3-4.

Huckins-Gang, H. E., 2003. Written Communication. Subject: "Updated Structural Geology of the U1a Complex.” Bechtel Nevada Memorandum No. B502-MT-03-0016 to R. G. Musick, Bechtel Nevada, 9 p. Las Vegas, NV.

Hull, J., 1988. “Thickness-Displacement Relationships for Deformation Zones.” Journal of Structural Geology, vol. 10, no. 4, pp. 431-435.

Laczniak, R. J., J. C. Cole, D. A. Sawyer, and D. A. Trudeau, 1996. Summary of Hydrogeologic Controls on the Ground-water Flow at the Nevada Test Site, Nye County, Nevada. U.S. Geological Survey Water-Resources Investigation Report 96-4109. Carson City, NV.

Lipman, P. W., 2000. “Calderas.” In: Haraldur, S., B. F. Houghton, S. R. McNutt, H. Rymer, and J. Stix, eds., Encyclopedia of Volcanoes, pp. 643-662. San Diego, CA: Academic Press.

Lipman, P. W., W. D. Quinlivan, W. J. Carr, and R. E. Anderson, 1966. Geologic Map of the Thirsty Canyon SE Quadrangle, Nye County, Nevada. U.S. Geological Survey Geologic Quadrangle Map GQ-489, scale, 1:24,000.

Lockner, D. A., H. Naka, H. Tanaka, H. Ito, and R. Ikeda, 2000. "Permeability and Strength of Core Samples from the Nojima Fault of the 1995 Kobe Earthquake.” In: Proceedings of the International Workshop on the Nojima Fault Core and Borehole Analysis. U.S. Geological Survey Open-File Report 00-129.

Minor, S. A, 1989. “Paleostress Investigation Near Rainier Mesa, Nevada Test Site.” In: Olsen, C. W., and J. A. Carter, eds., Proceedings of the Fifth Symposium on Containment of Underground Nuclear Explosions, vol. 2, pp. 457-482. CONF-8909163, Livermore, CA.

Minor, S. A., and M. R. Hudson, 2006. Regional Survey of Structural Properties and Cementation Patterns of Fault Zones in the Northern Part of the Albuquerque Basin, New Mexico: Implications for Ground-Water Flow. U.S. Geological Survey Professional Paper 1719, 28 p.

National Research Council, Committee on Fracture Characterization and Fluid Flow and U.S. National Committee for Rock Mechanics, 1996. Rock Fractures and Fluid Flow: Contemporary Understanding and Applications, 551 p. Washington, DC: National Academy Press.

National Security Technologies, LLC, 2007. A Hydrostratigraphic Model and Alternatives for the Groundwater Flow and Contaminant Transport Model of Corrective Action Unit 99: Rainier Mesa-Shoshone Mountain, Nye County, Nevada. DOE/NV/25946--146. Las Vegas, NV. 
Nevada Bureau of Mines and Geology, 1996. County Digital Geologic Mapping Project-Final Report. Open-File Report 97-1, scale 1:250,000.

NRC, see National Research Council.

NSTec, see National Security Technologies, LLC.

Rawling, G. C., and L. B. Goodwin, 2003. "Cataclasis and Particulate Flow in Faulted, Poorly Lithified Sediments.” Journal of Structural Geology, vol. 25, pp. 317-331.

Rawling, G. C., L. B. Goodwin, and J. L. Wilson, 2001. “Internal Architecture, Permeability Structure, and Hydrologic Significance of Contrasting Fault-Zones Types.” Geology, vol. 29, no. 1, pp. 43-46.

Sawyer, D.A., R. J. Fleck, M. A. Lanphere, R. G. Warren, and D. E. Broxton, 1994. "Episodic Caldera Volcanism in the Miocene Southwest Nevada Volcanic Field: Revised Stratigraphic Caldera Framework, ${ }^{40} \mathrm{Ar} /{ }^{39} \mathrm{Ar}$ Geochronology and Implications for Magmatism and Extension.” Geological Society of America Bulletin, vol. 67, no. 10, pp. 1,304-1,318.

Schultz, R. A., and H. Fossen, 2008. “Terminology for Structural Discontinuities.” American Association of Petroleum Geologists Bulletin, vol. 92, no. 7, pp. 853-867.

Sigda, J. M., L. B. Goodwin, P. S. Mozley, and J. L. Wilson, 1999. "Permeability Alteration in Small-Displacement Faults in Poorly Lithified Sediments: Rio Grande Rift, Central New Mexico.” In: Haneberg, W. C., P. S. Mozley, J. C. Moore, and L. B. Goodwin, eds., Faults and Subsurface Fluid Flow in the Shallow Crust. American Geophysical Union Geophysical Monograph 113, pp. 51-68.

Stock, J. M., J. H. Healy, S. H. Hickman, and M. D. Zoback, 1985. “Hydraulic Fracturing Stress Measurements at Yucca Mountain, Nevada, and Relationship to Regional Stress Field.” Journal of Geophysical Research, vol. 90, pp. 8,691-8,706.

Sweetkind, D. S., and R. M. Drake, II, 2007. Characteristics of Fault Zones in Volcanic Rocks Near Yucca Flat, Nevada Test Site, Nevada. U.S. Geological Survey Open-File Report 2007-1293, 52 p. Denver, CO.

Wilson, J. E., L. B. Goodwin, and C. J. Lewis, 2003. “Deformation Bands in Nonwelded Ignimbrites: Petrophysical Controls on Fault-Zone Deformation and Evidence of Preferential Fluid Flow.” Geology, vol. 31, no. 10, pp. 837-840.

Winograd, I. J., and W. Thordarson, 1975. Hydrogeologic and Hydrochemical Framework South-Central Great Basin, Nevada-California, with Special Reference to the Nevada Test Site. U.S. Geological Survey Professional Paper 712-C, 126 p. Washington, DC.

Yielding, G., B. Freeman, and D. T. Needham, 1997. “Quantitative Fault Seal Prediction.” American Association of Petroleum Geologists Bulletin, vol. 81, no. 6, pp. 897-917. 


\section{Distribution List}

\section{$\underline{\text { Copies }}$}

W. R. Wilborn

U.S. Department of Energy

1 paper/1 CD

National Nuclear Security Administration

Nevada Site Office

Environmental Restoration Division

P.O. Box 98518, M/S 505

Las Vegas, NV 89193-8518

U.S. Department of Energy

National Nuclear Security Administration

Nevada Site Office

Technical Library

P.O. Box 98518, M/S 505

Las Vegas, NV 89193-8518

U.S. Department of Energy

National Nuclear Security Administration

Nevada Site Office

Public Reading Facility

c/o Nuclear Testing Archive

P.O. Box 98521, M/S 400

Las Vegas, NV 89193-8521

U.S. Department of Energy

Office of Scientific and Technical Information

1 CD (uncontrolled)

P.O. Box 62

Oak Ridge, TN 378831-0061

N. M. Becker

Los Alamos National Laboratory

P.O. Box 1663, EES-6, M/S T-003

Los Alamos, NM 87545-1663

B. M. Crowe

Environmental Restoration Project

2 CDs (uncontrolled)

U.S. Department of Energy

National Nuclear Security Administration

Nevada Site Office

P.O. Box 98518, M/S 505

Las Vegas, NV 89193-8518

E. M. Kwicklis

Los Alamos National Laboratory

1 electronic copy (uncontrolled)

P. O. Box 1663

Los Alamos, NM 87545-1663

1 paper/1 CD

1 paper/1 CD

$1 \mathrm{CD}$

Dist-1 


\section{Distribution List}

$\underline{\text { Copies }}$

S. Marutzky

1 paper/1CD

Stoller-Navarro Joint Venture

232 Energy Way, M/S 439

Las Vegas, NV 89129

P. K. Ortego

National Security Technologies, LLC

1 paper/1 CD

P.O. Box 98521, NLV082

Las Vegas, NV 89193-8521

G. A. Pawloski

1 paper/ $1 C D$

Lawrence Livermore National Laboratory

P.O. Box 808

Livermore, CA 94551-0808

G. Ruskauff

$1 \mathrm{CD}$

Stoller-Navarro Joint Venture

232 Energy Way, MS 439

North Las Vegas, NV 89030

C. E. Russell

Desert Research Institute

755 East Flamingo Road

P.O. Box 19040

Las Vegas, NV 89119-7363

Stoller-Navarro Library

Stoller-Navarro Joint Venture

232 Energy Way, M/S 439

North Las Vegas, NV 89030

B. K. Thompson

Water Resources, Nevada District

U.S. Geological Survey

160 N. Stephanie Street

Henderson, NV 89074

A. V. Wolfsberg Los Alamos National Laboratory

P. O. Box 1663, EES-6, M/S T003

Los Alamos, NM 87545-1663

M. Zavarin

1 paper/1 CD

Lawrence Livermore National Laboratory

P. O. Box 808

Livermore, CA 94551-0808 


\section{APPENDIX A}

\section{Fault Descriptions and Photographs}





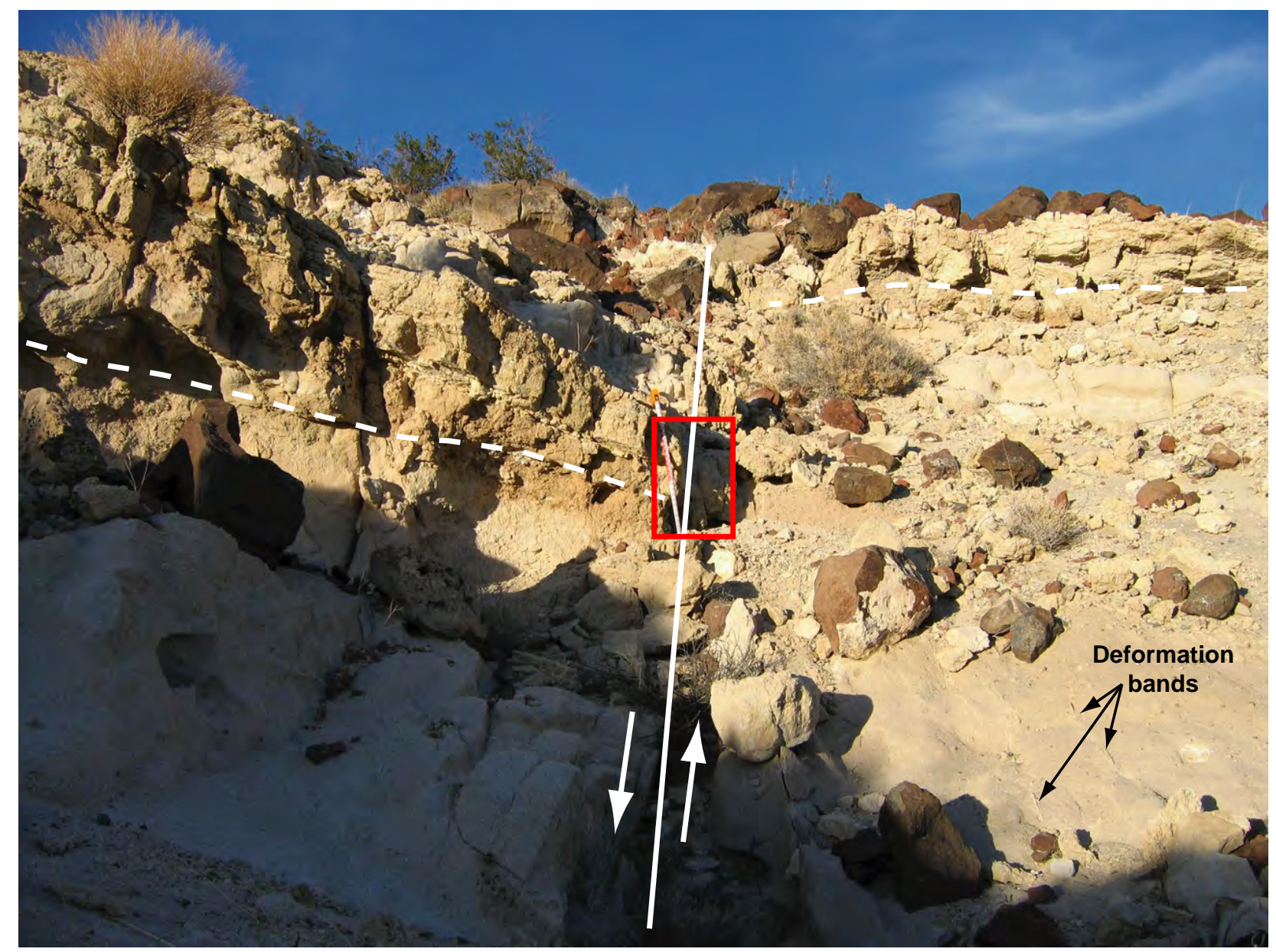

Normal fault within vitric-tuff aquifer.

Staff in upper photograph is

1 meter $(\mathrm{m})$ (3 feet [ft]). Red square in upper photograph indicates location of close-up photograph at right.

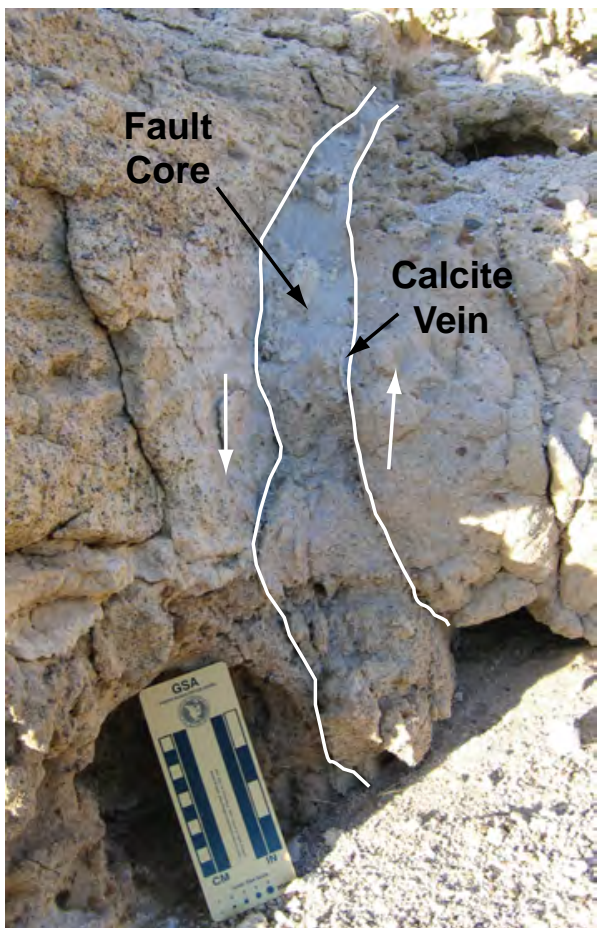

Figure A-1

Fault Station FF-3 

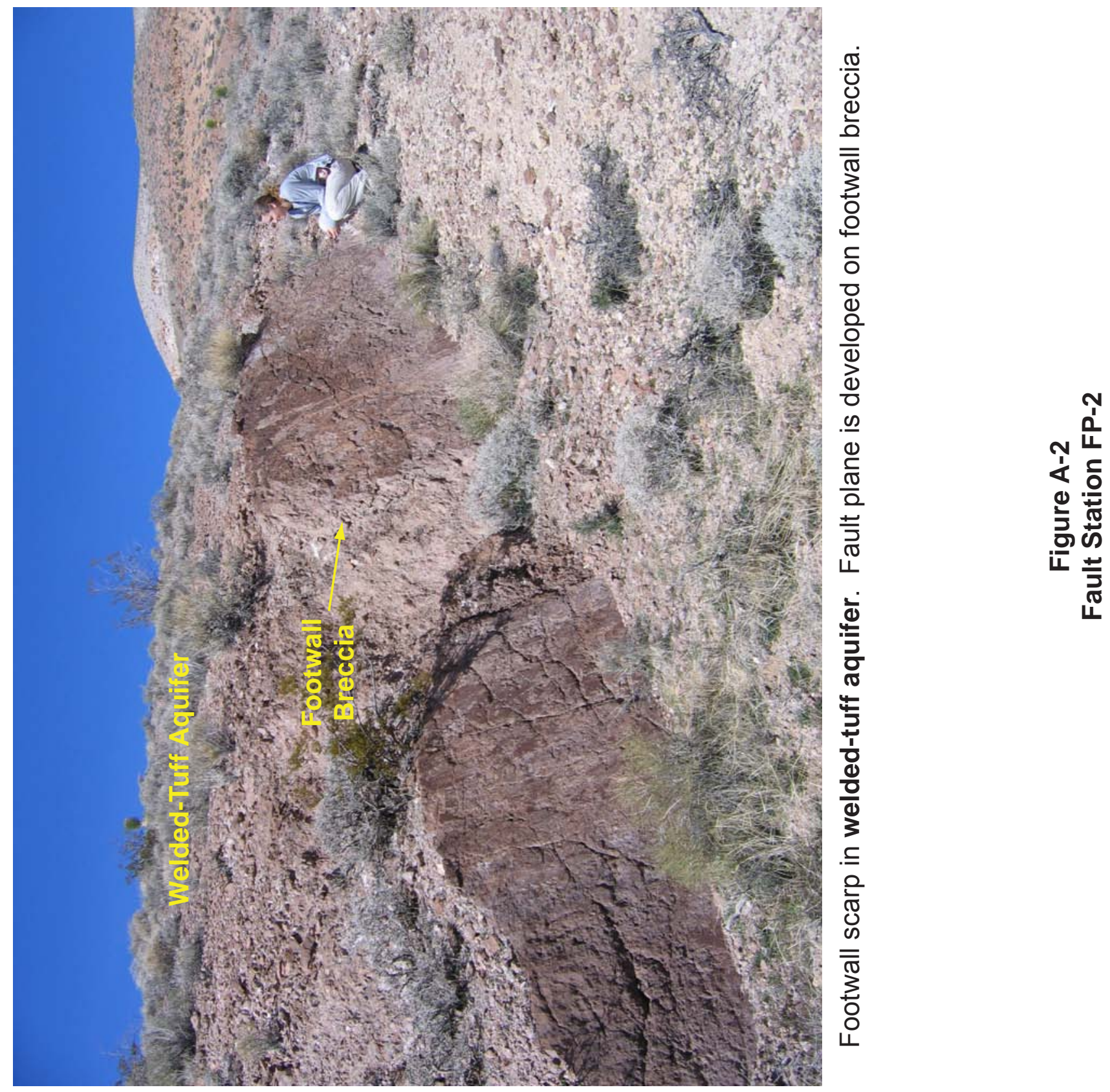


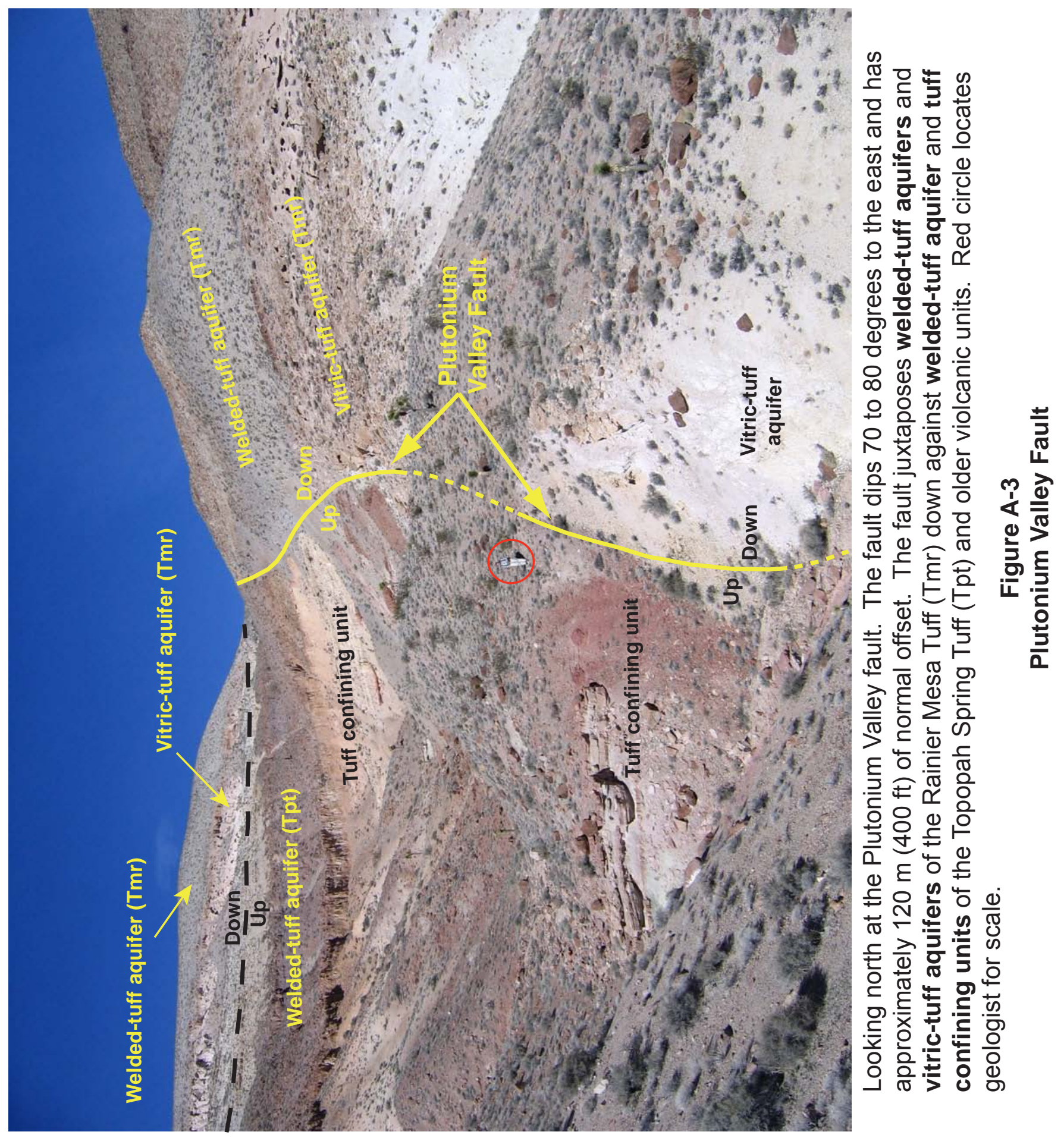




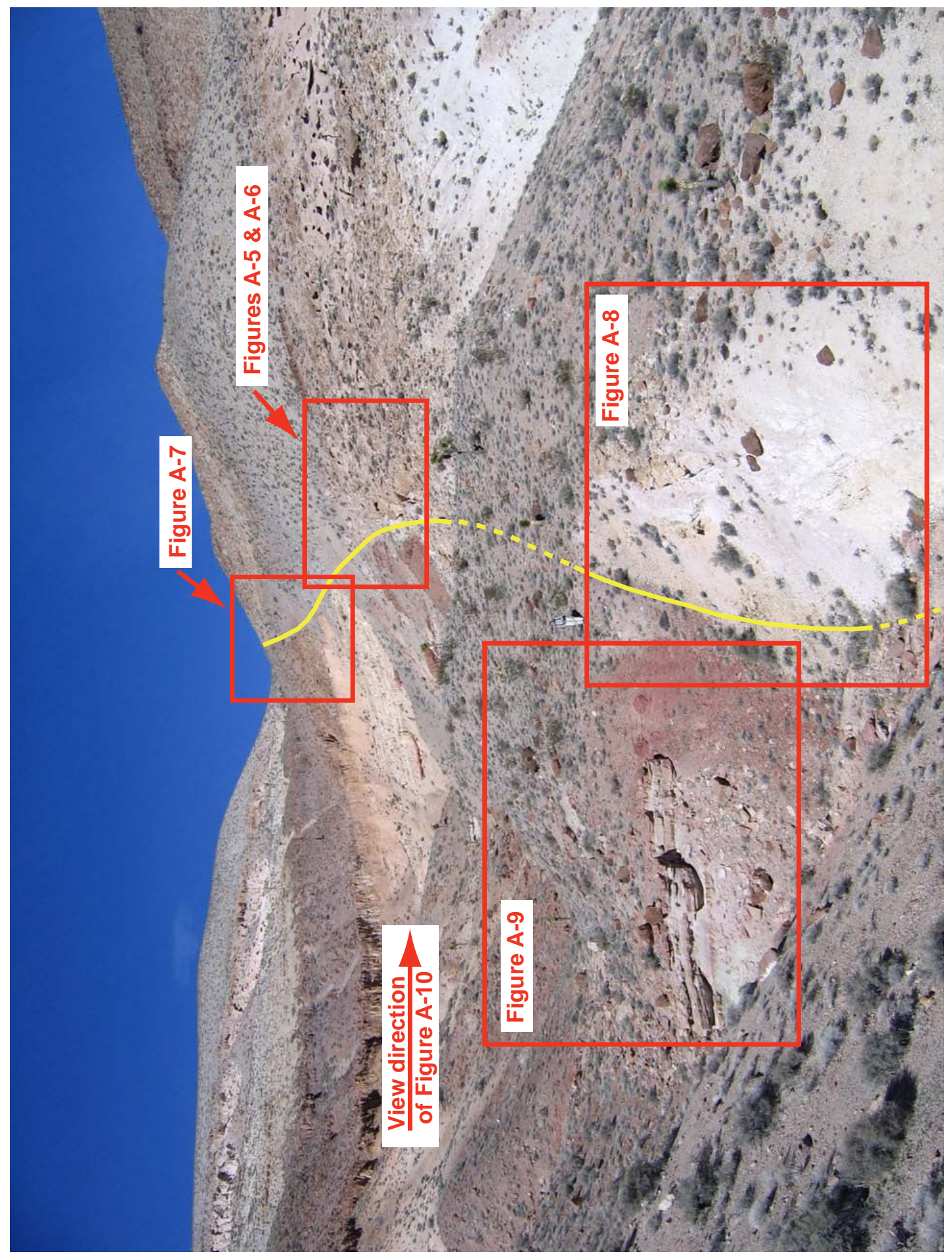

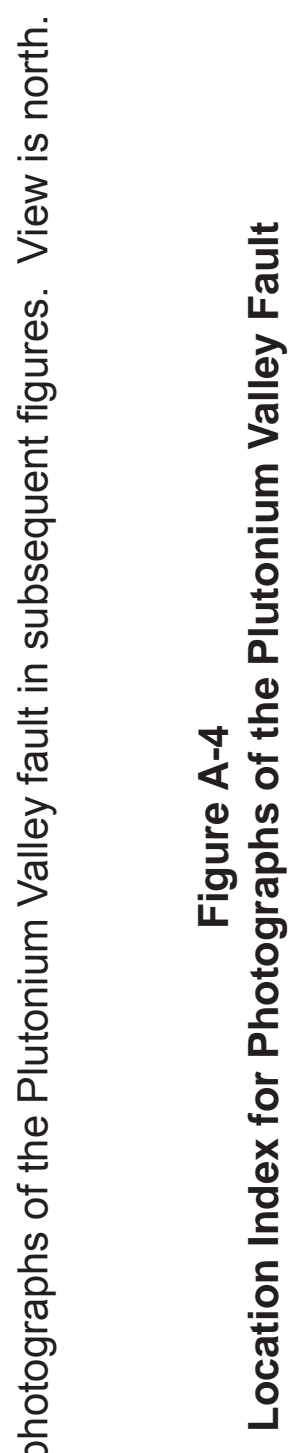




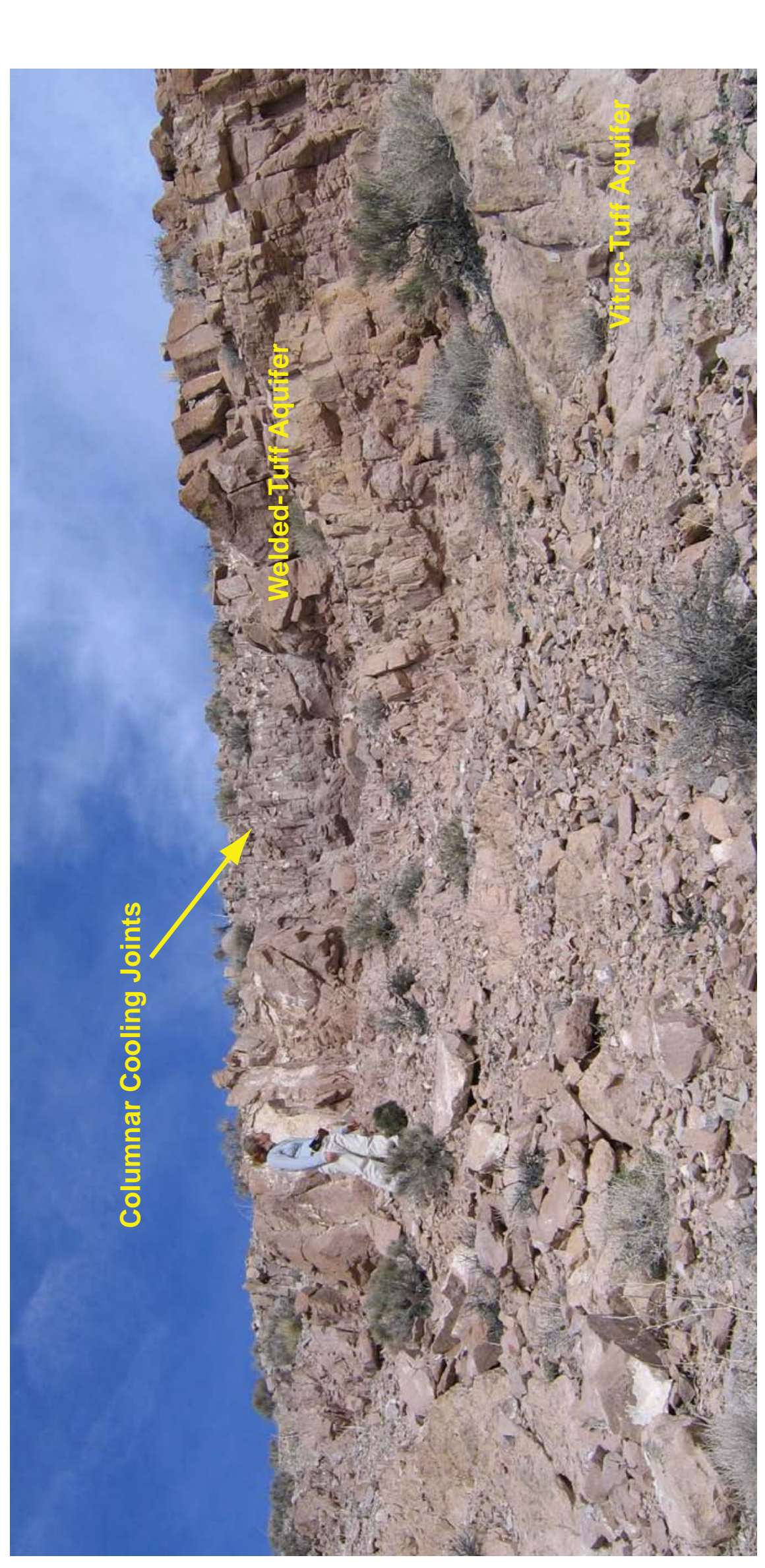

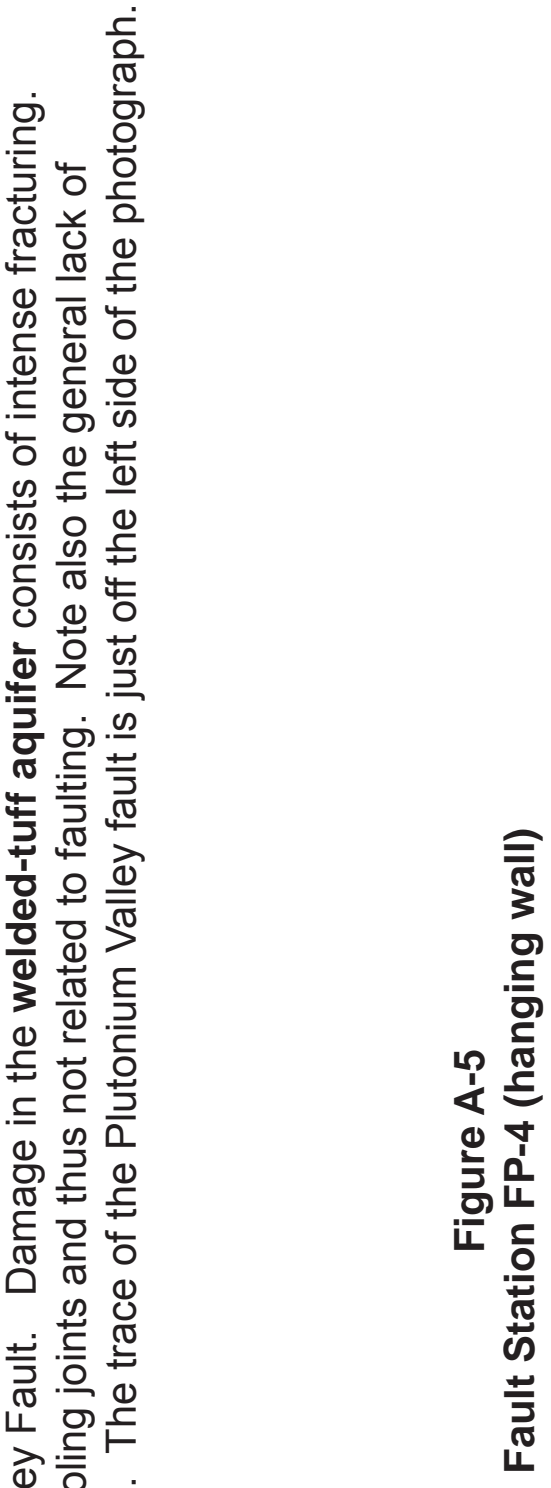

产 8

ह 을 중

은 Ф出

금

(1)

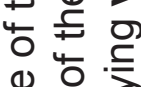

(1) 은

을 ฮ

๑)

त

है드

宁 ⿺辶.

$3 \geqslant 3$

응

可 ब

京 


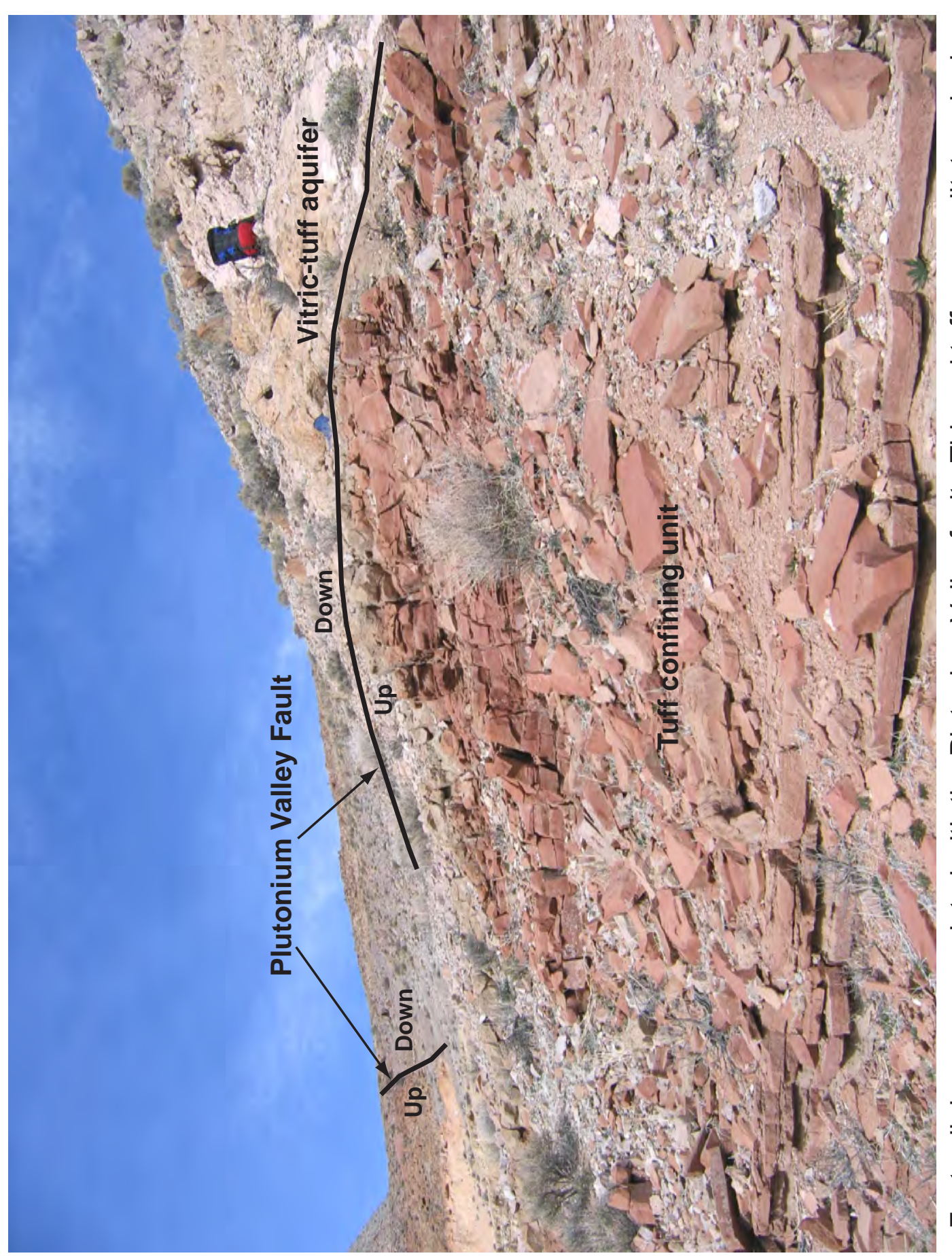

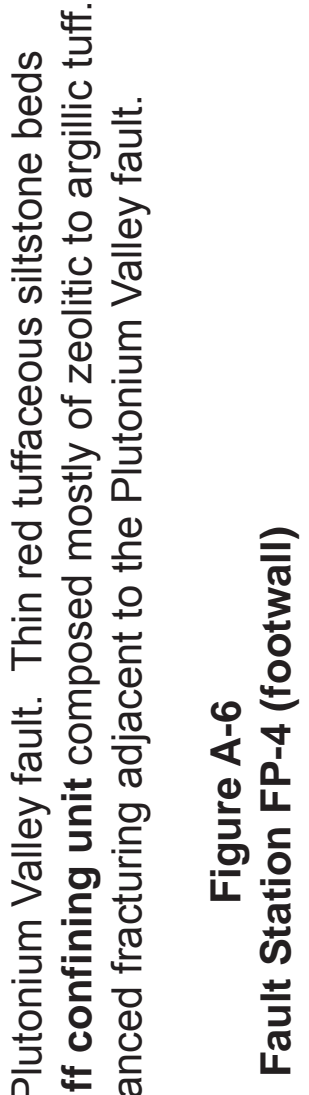
인 넝 采 $\frac{1}{3} \frac{1}{0}$ 어 \pm क

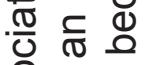
क् (1) 范 잉 음 ह. 宁 㐫 宁 $3 . \subseteq \Phi$

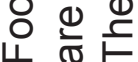



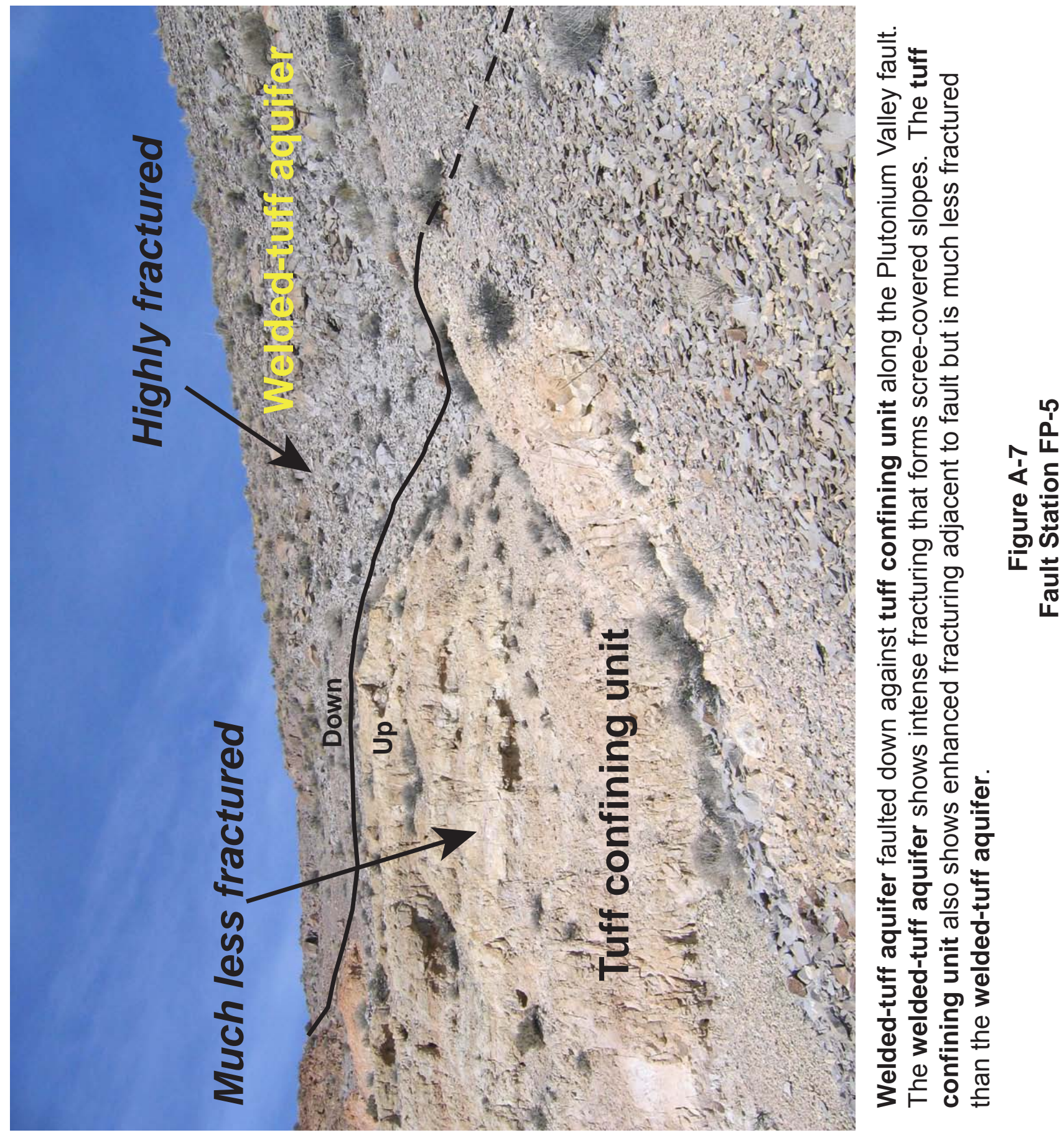

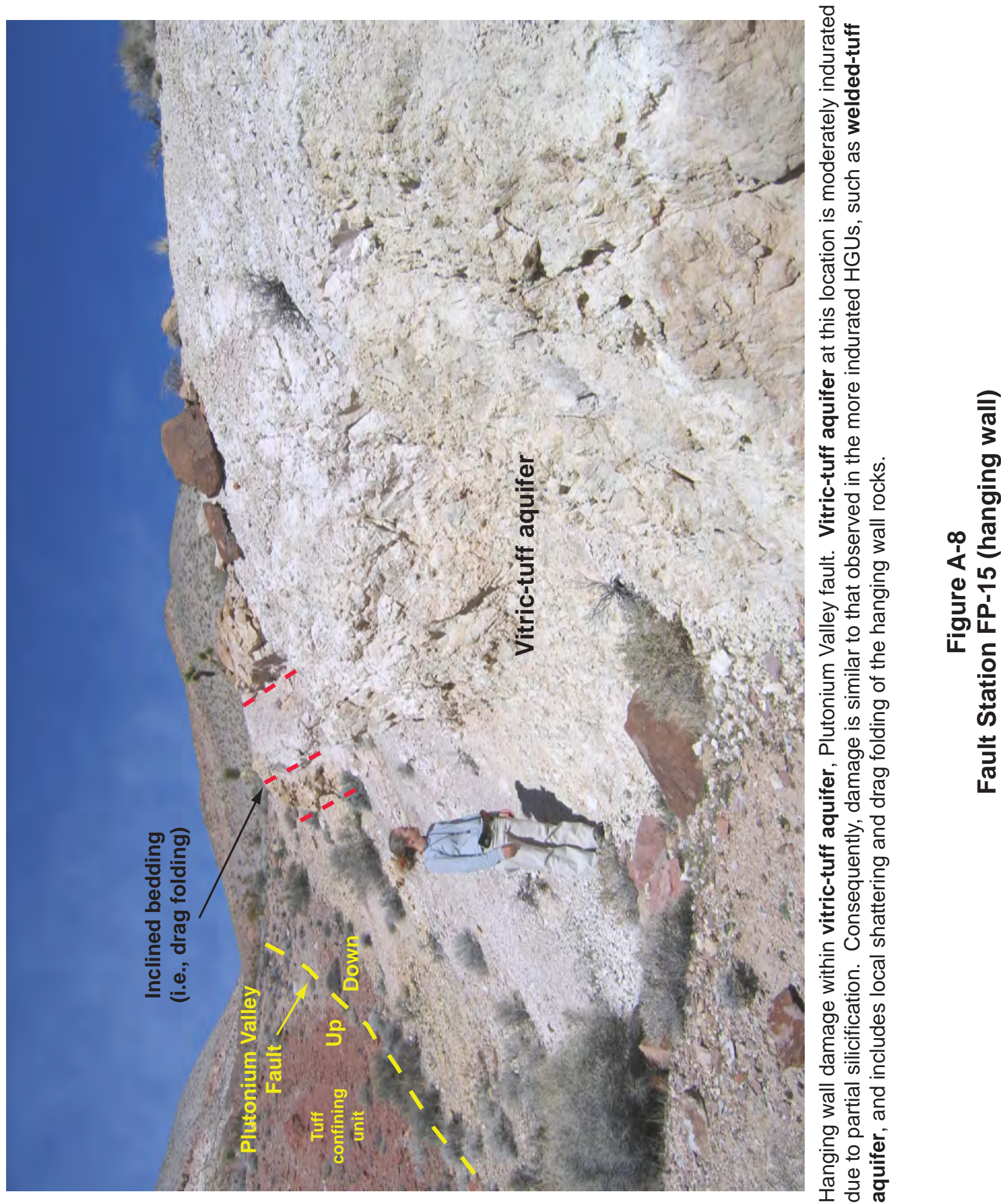

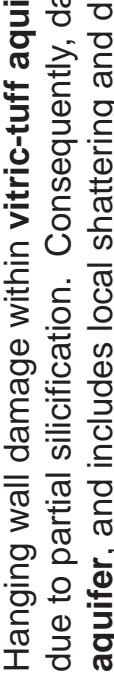




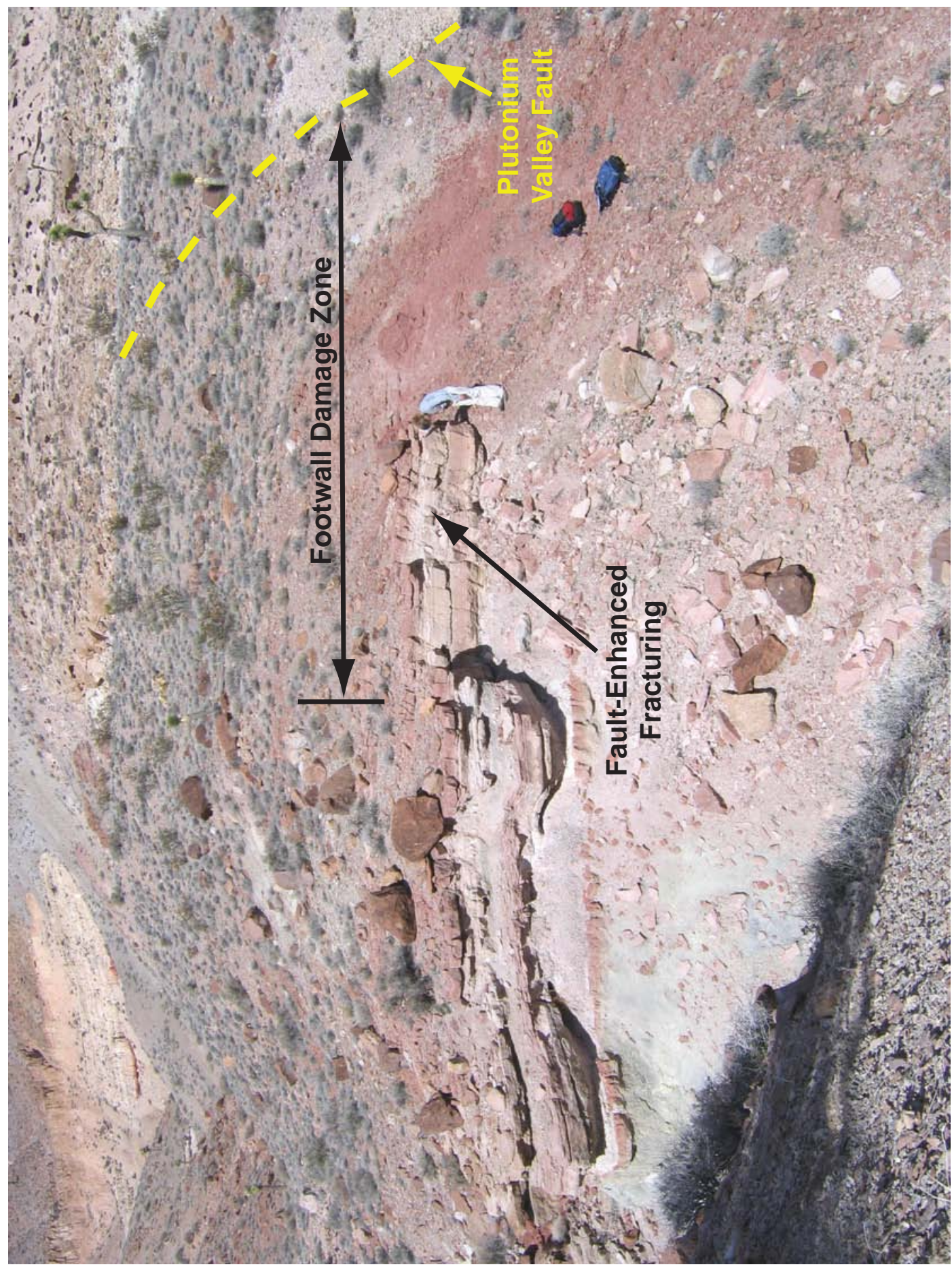

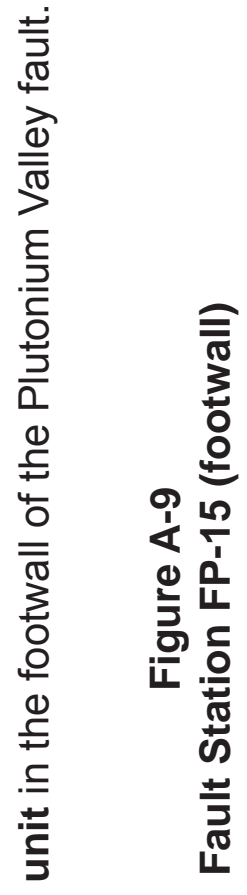




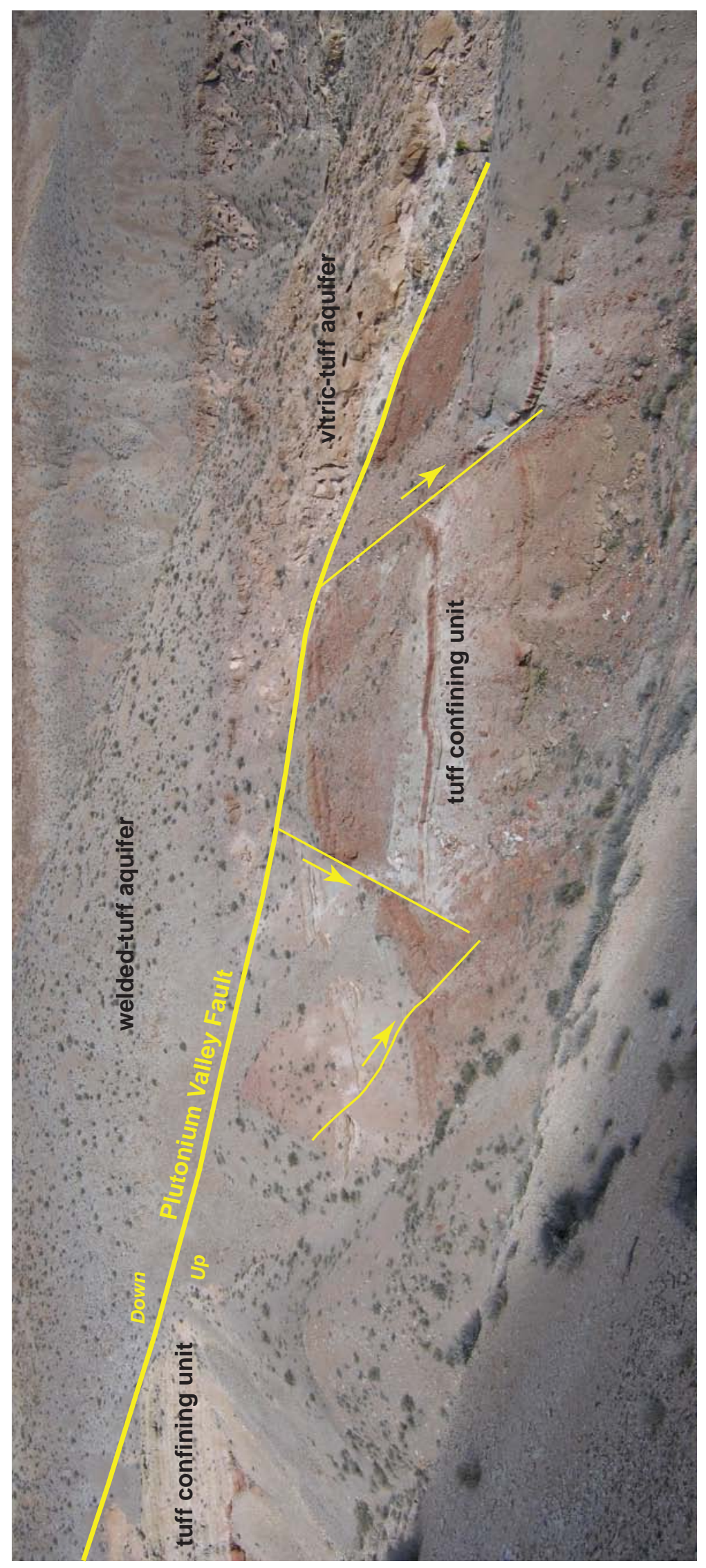

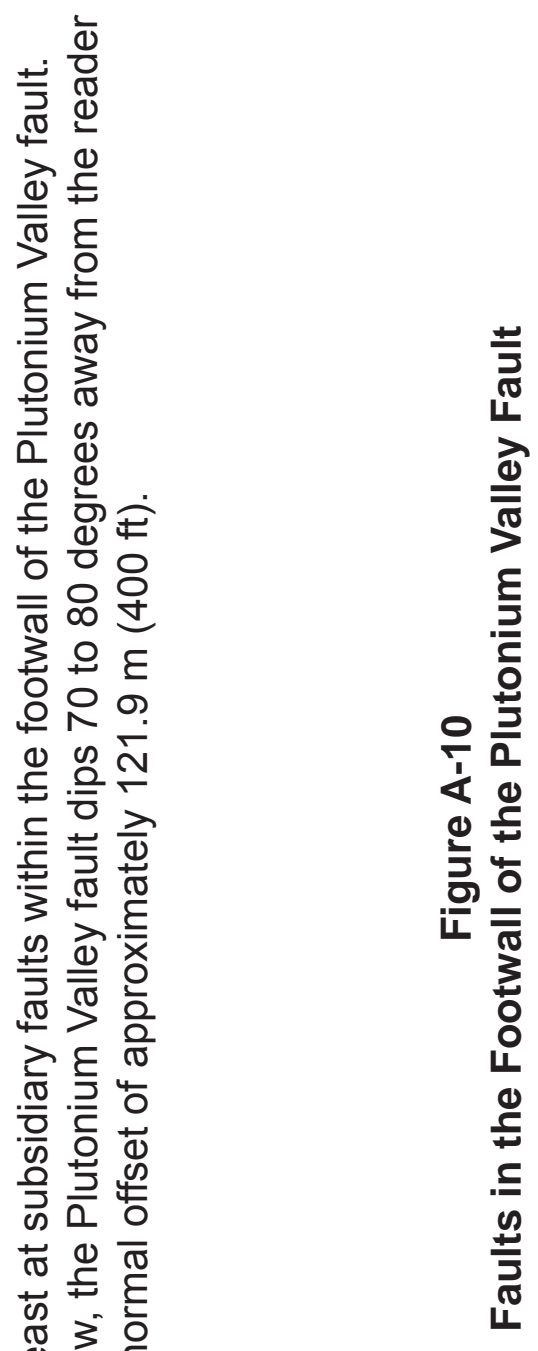



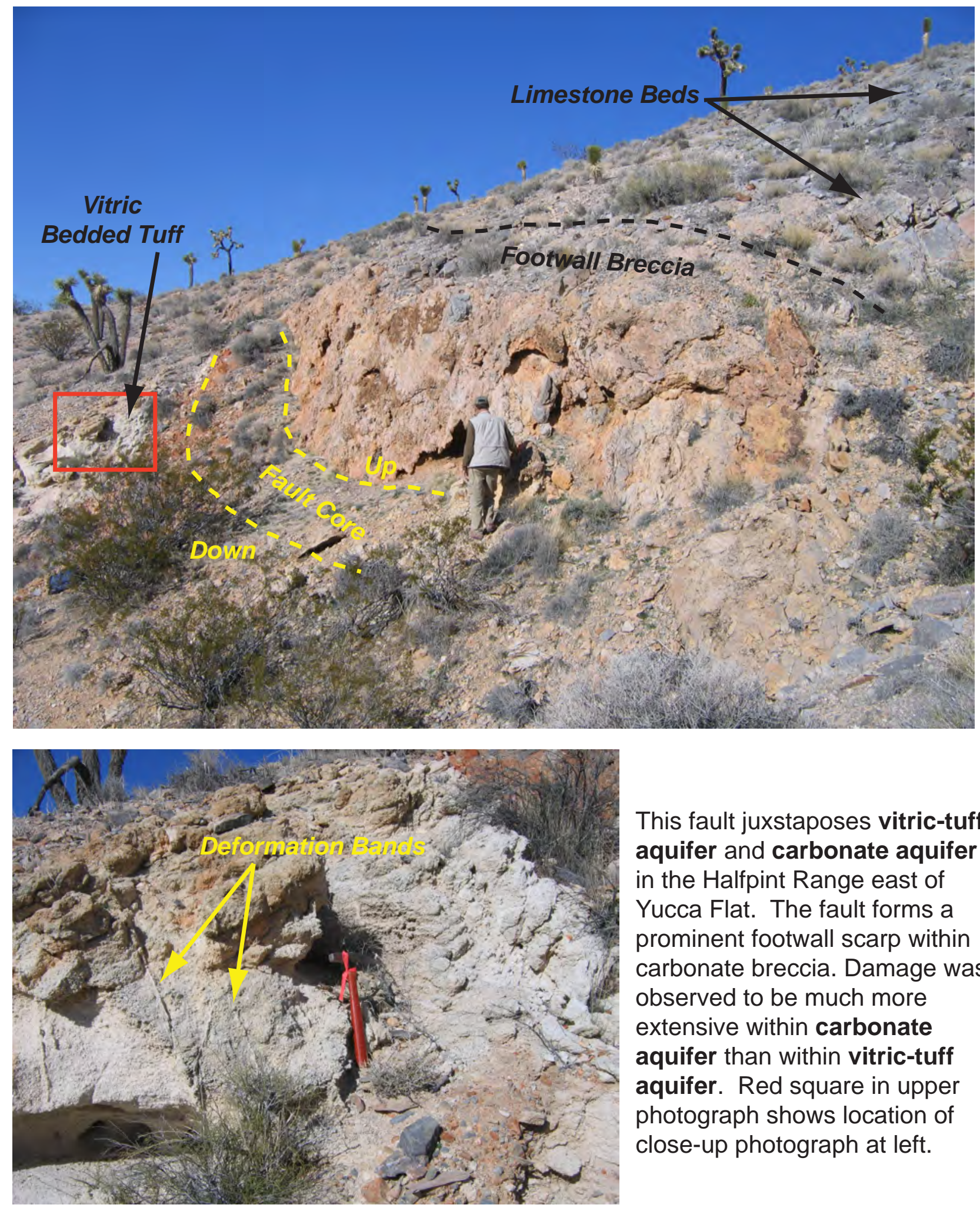

This fault juxstaposes vitric-tuff aquifer and carbonate aquifer in the Halfpint Range east of Yucca Flat. The fault forms a prominent footwall scarp within carbonate breccia. Damage was observed to be much more extensive within carbonate aquifer than within vitric-tuff aquifer. Red square in upper photograph shows location of close-up photograph at left.

Figure A-11

Fault Station PR-13 


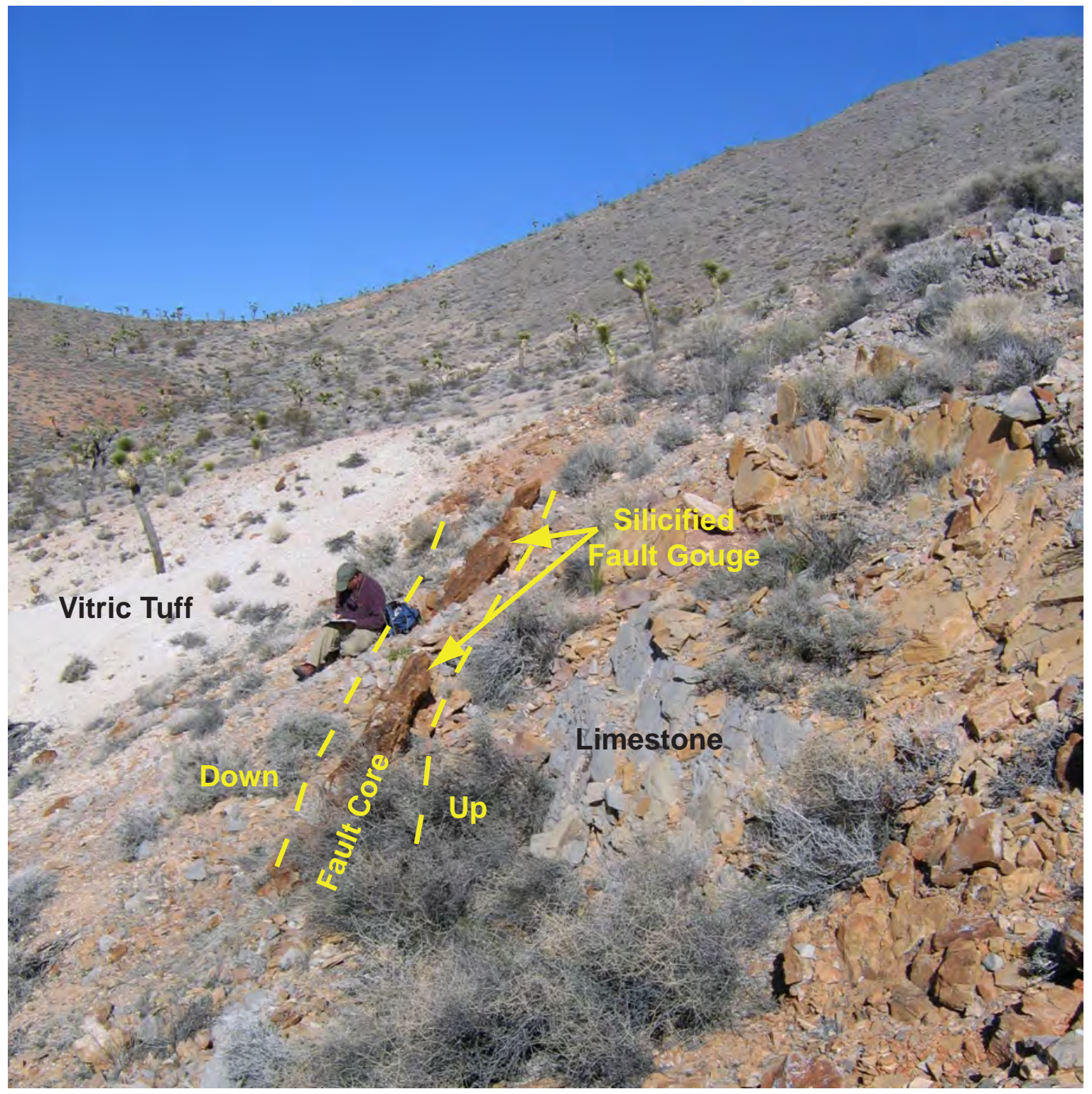

Looking north at Fault Station PR-14, showing exposure of silicified fault core material.

Figure A-12

Fault Station PR-14 


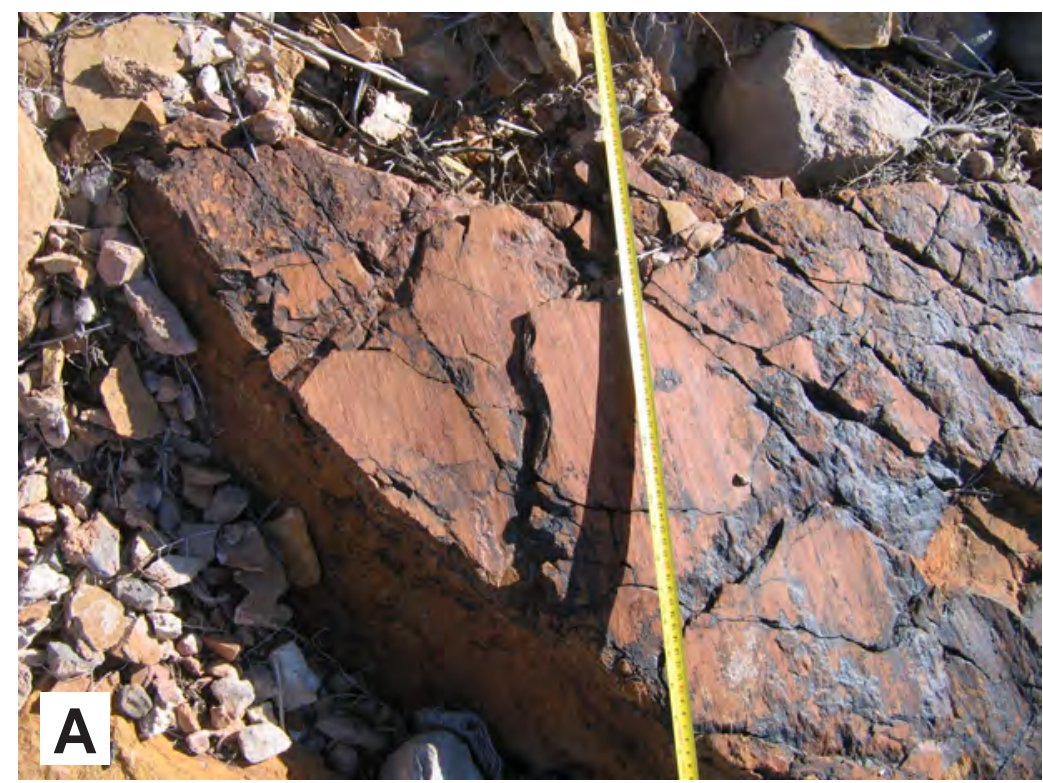

Close-up of polished and grooved fault surface developed on silicified fault gouge at PR-14.

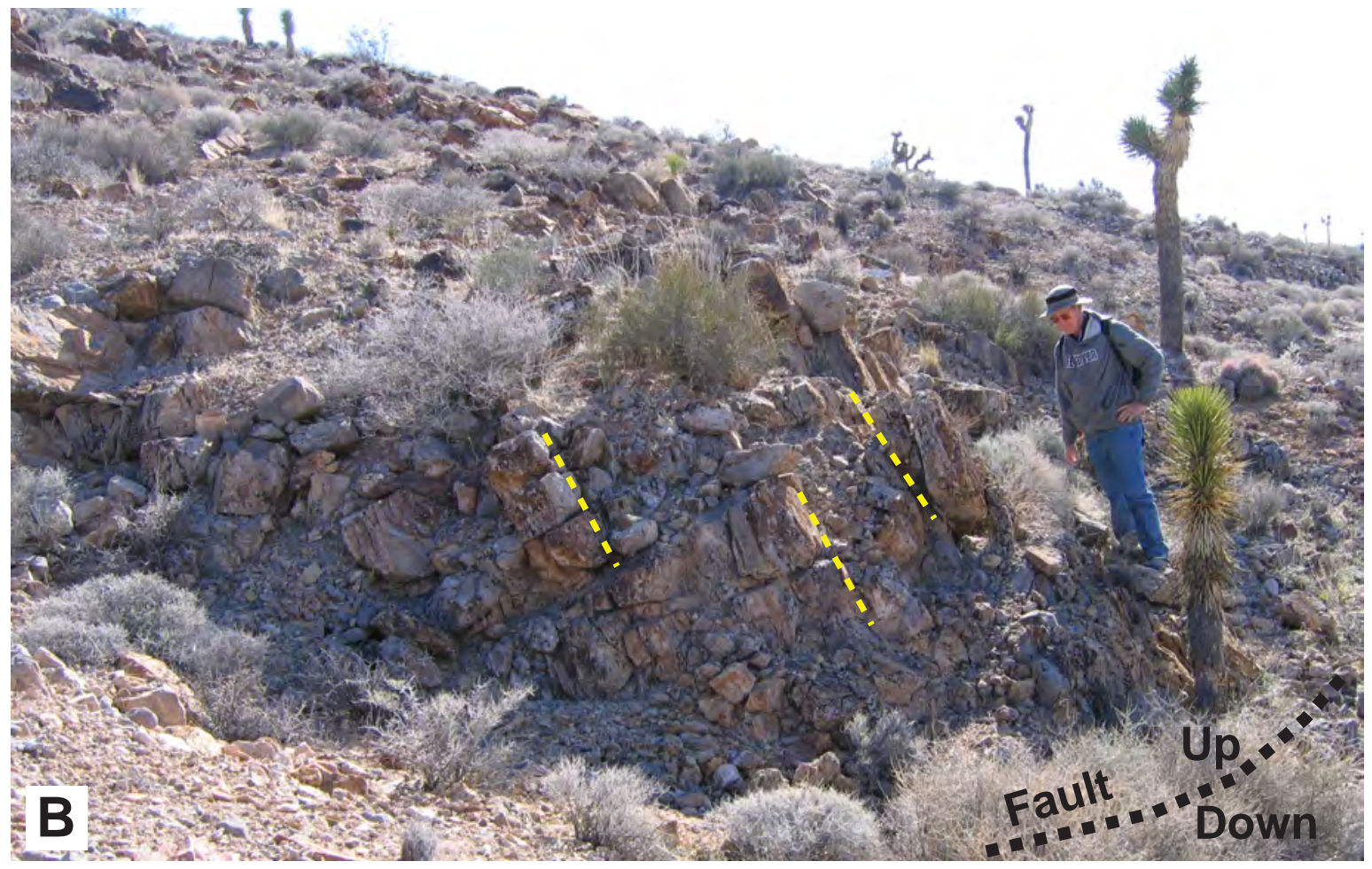

Exposure of hanging wall damage zone within carbonate aquifer just north of PR-14 showing steeply dipping limestone beds (yellow dashed lines) resulting from drag folding along fault.

Figure A-13

Fault Station PR-14 


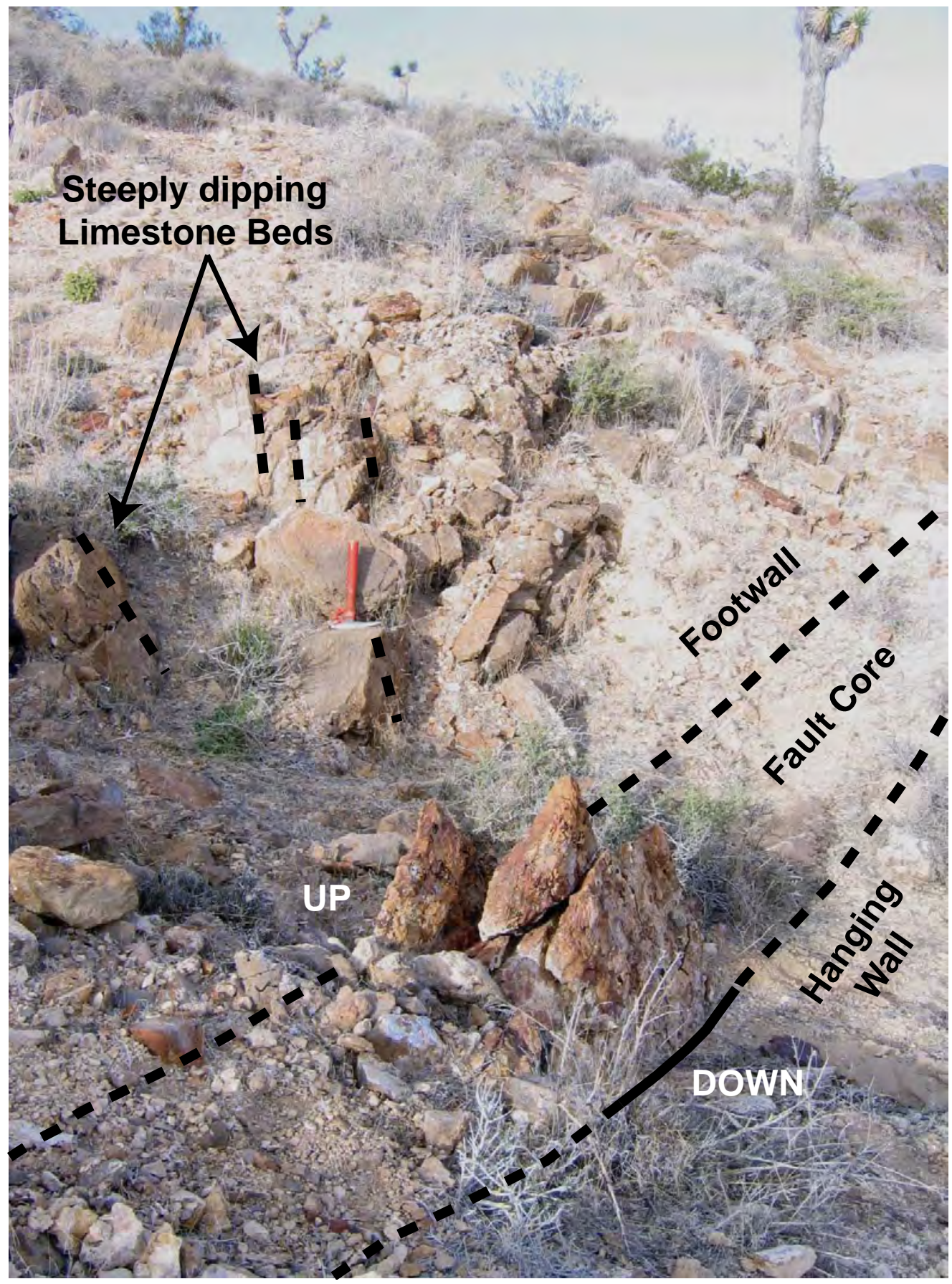

Photograph at Station PR-21 showing fault core and footwall damage zone within carbonate aquifer. Damage includes steeply dipping limestone beds dragged down by movement along fault. Note rock hammer for scale.

Figure A-14

Fault Station PR-21 


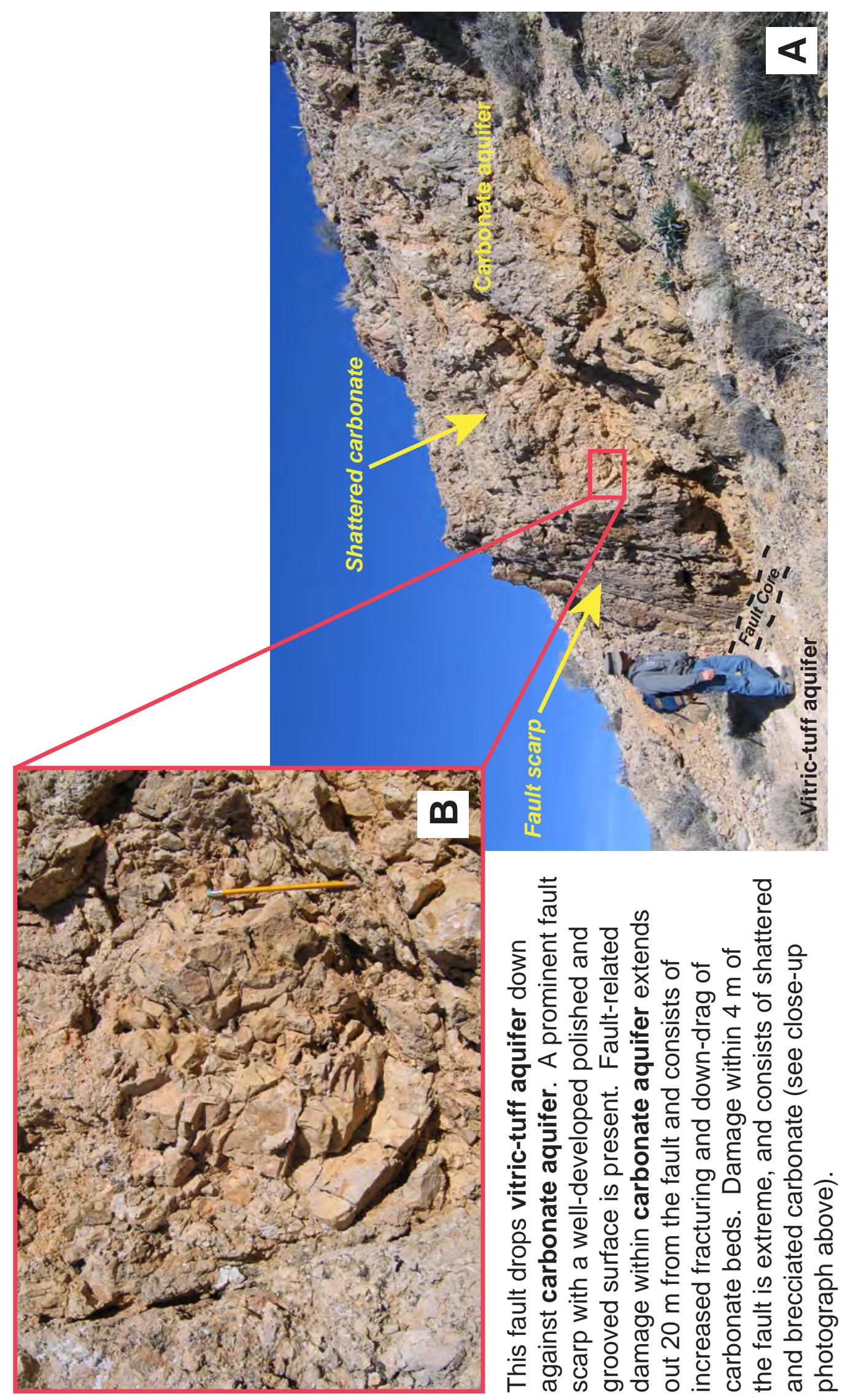

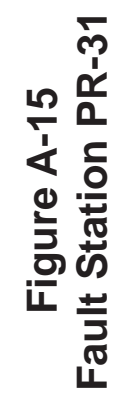




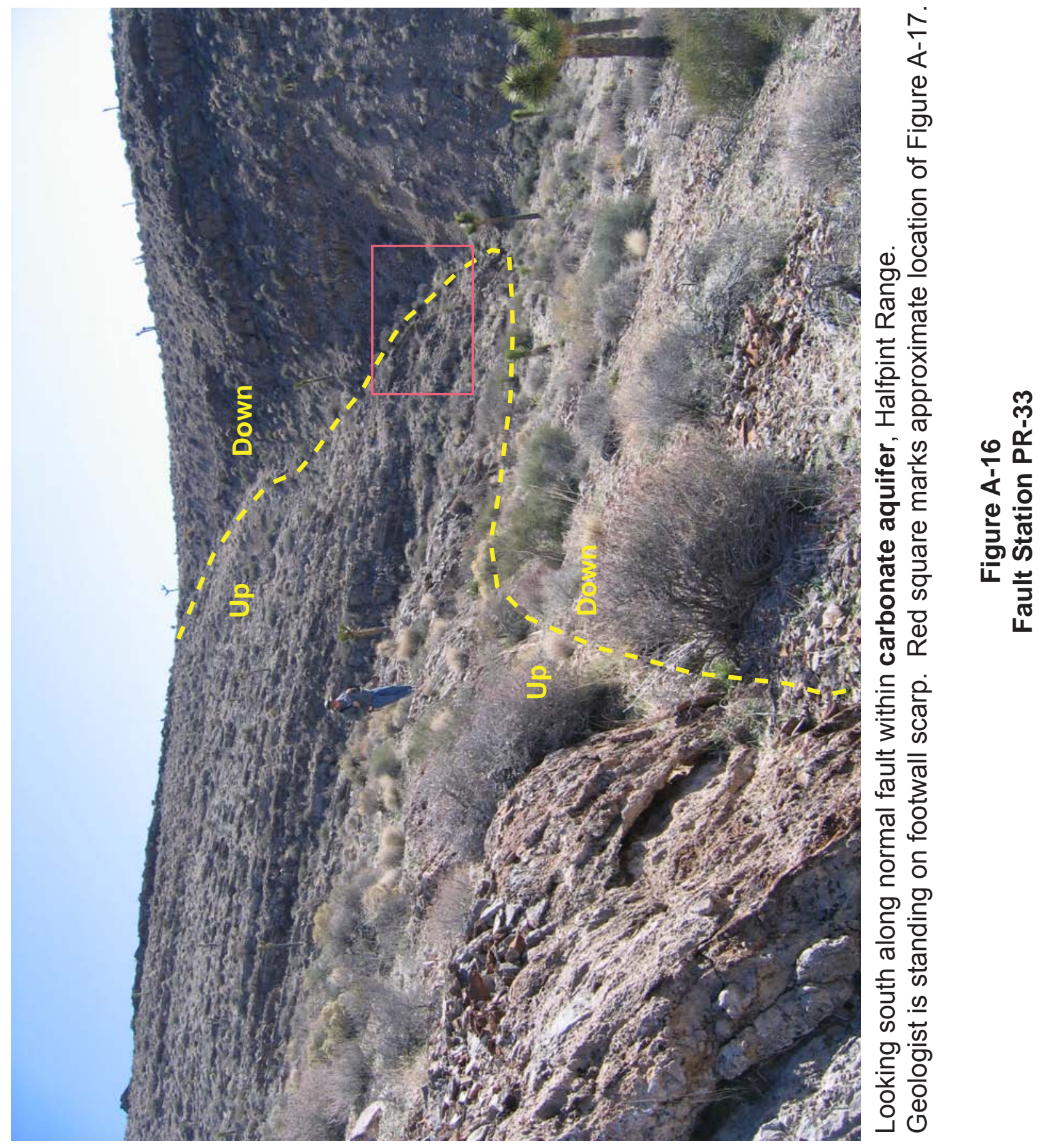




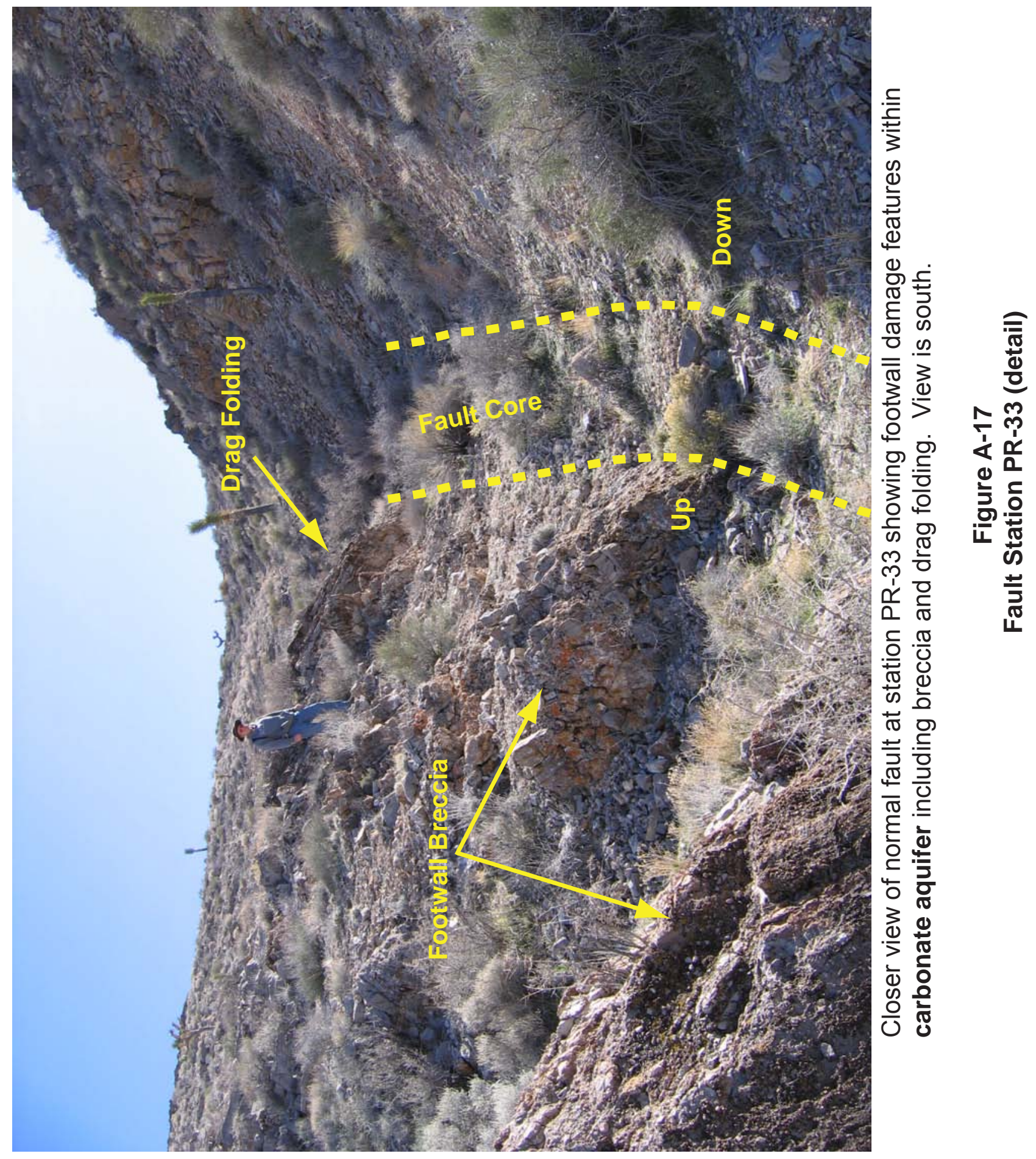




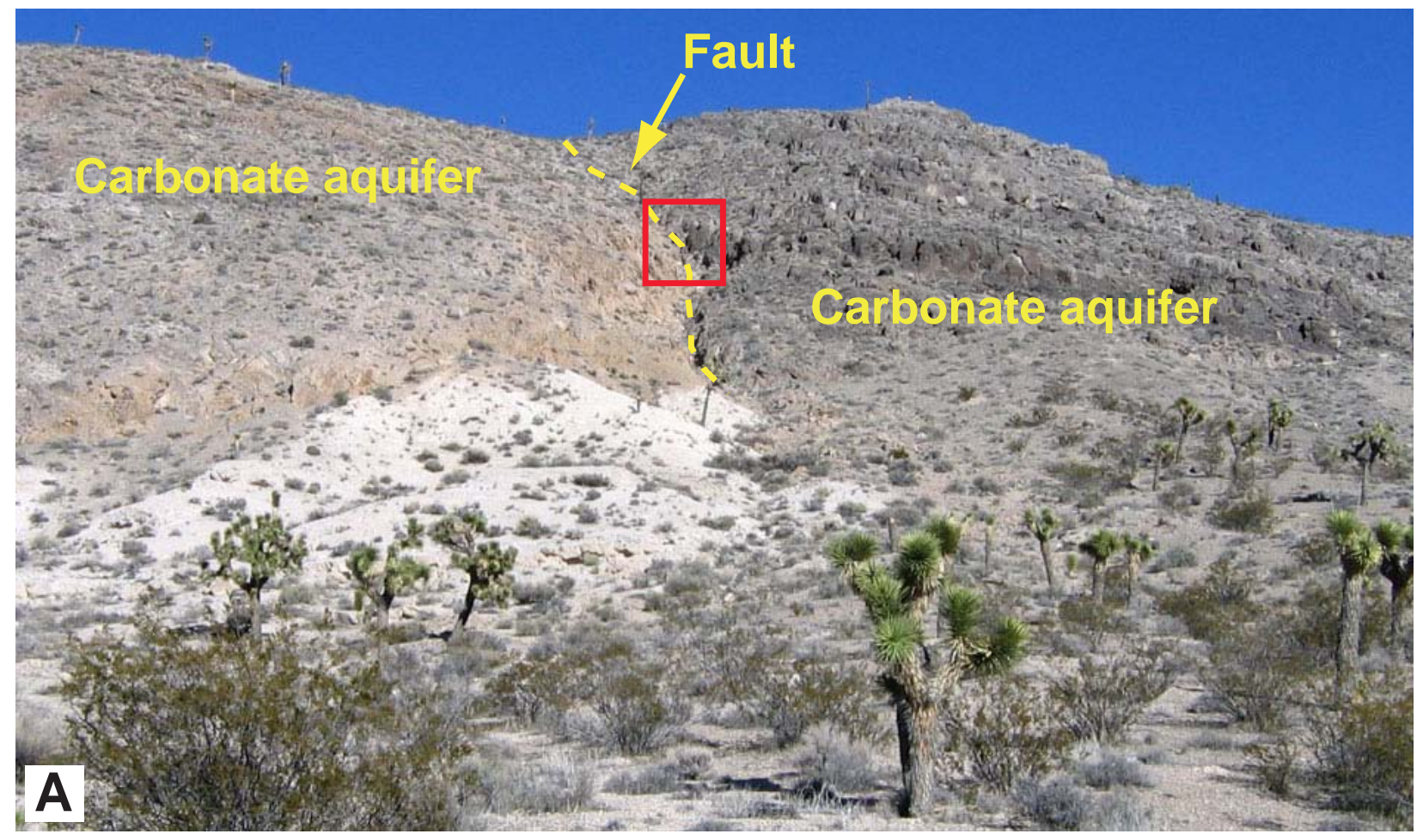

Looking west at fault within carbonate aquifer, Halfpint Range. Red square shows location of photographs in Figures A-18B and A-19A and A-19B.

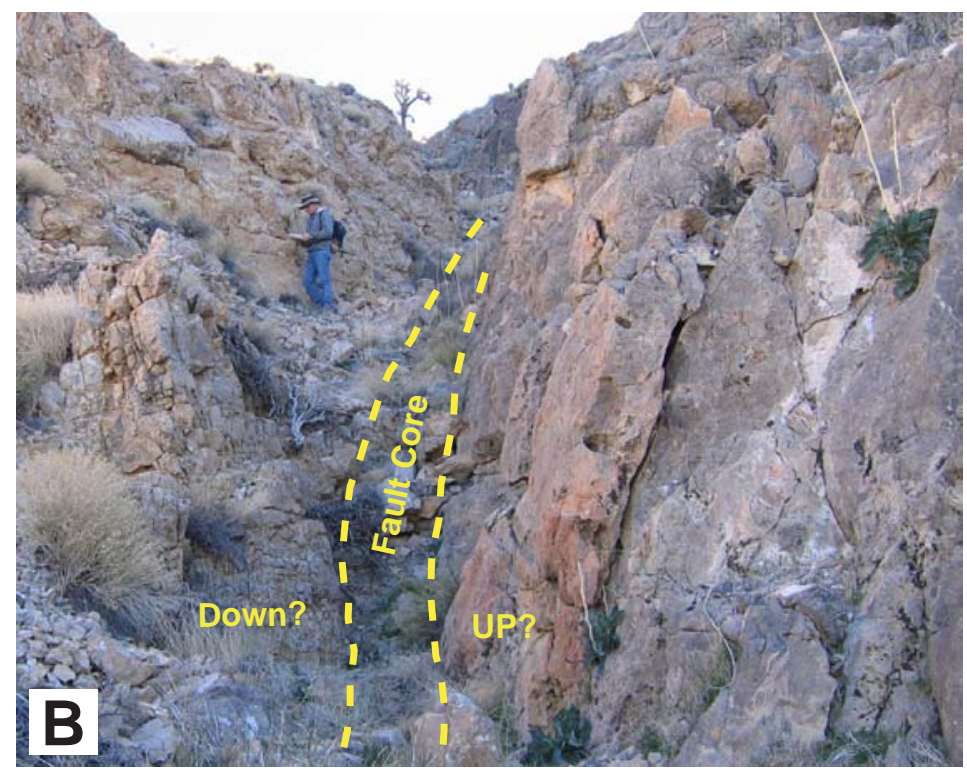

Closer view of fault at PR-65 showing the narrow fault core zone.

Figure A-18

Fault Station PR-65 (part one) 


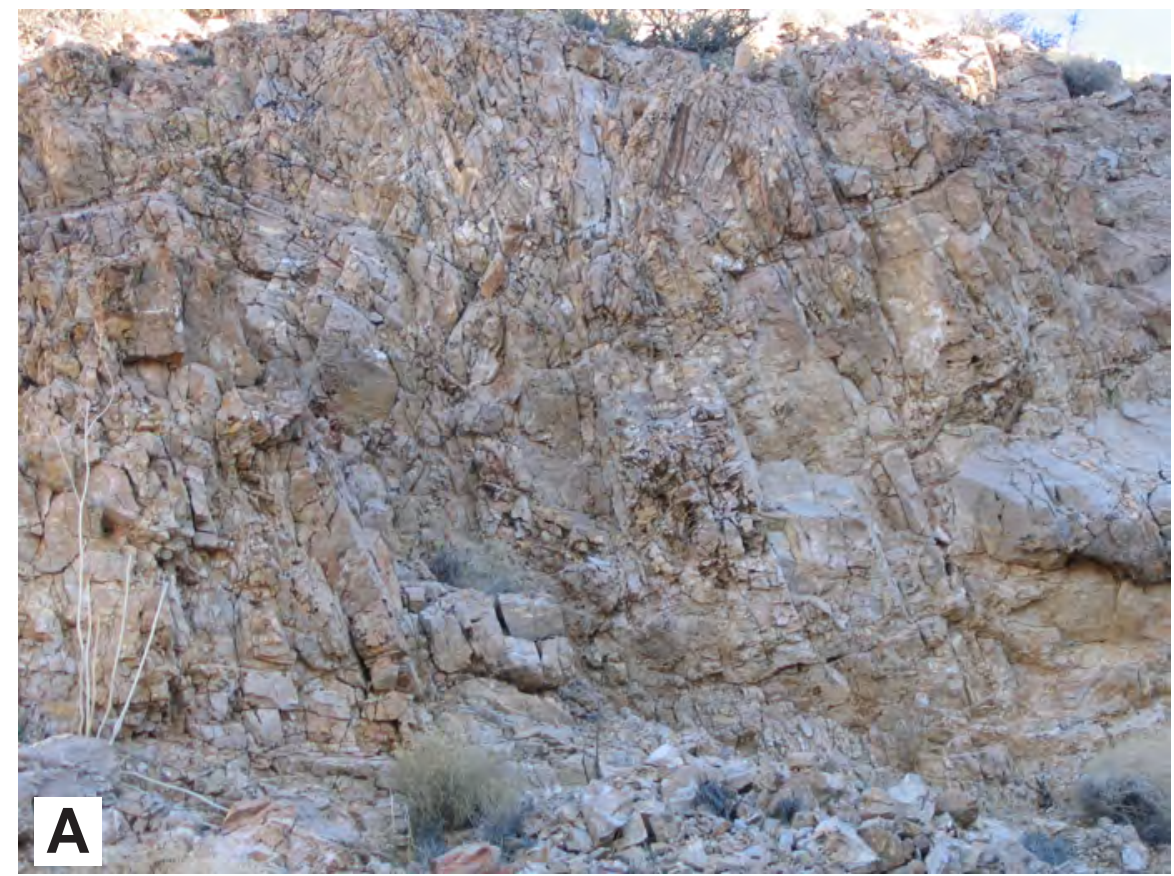

Intense fracturing of carbonate aquifer within damage zone on north side of fault at Station PR-65. Exposure is approximately $3.0 \mathrm{~m}(10 \mathrm{ft})$ high.

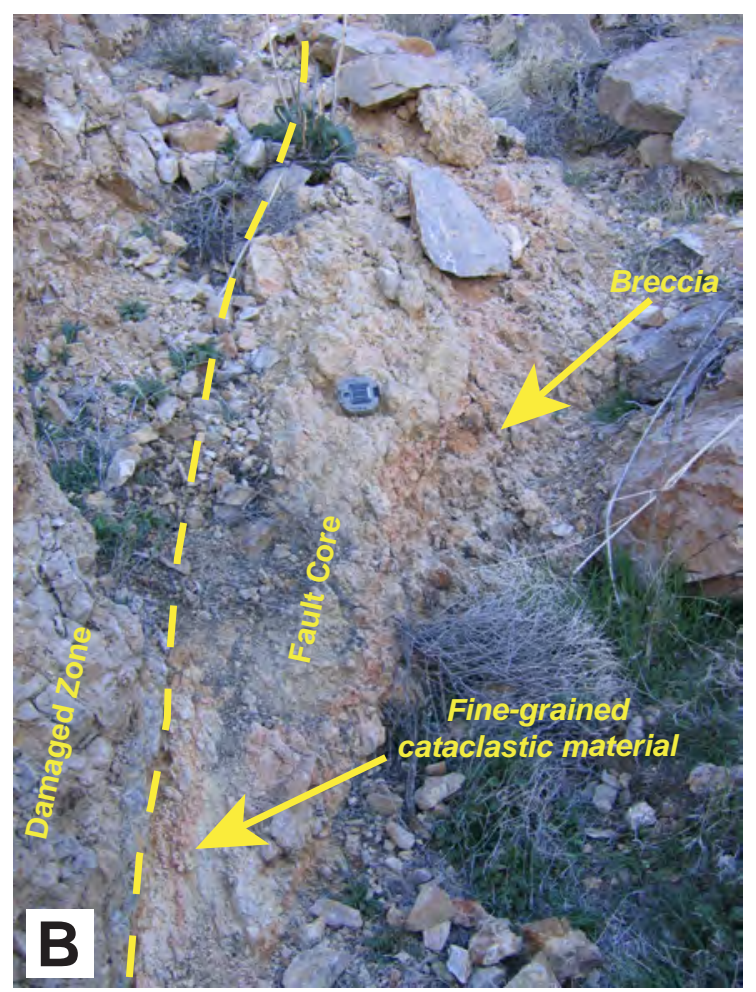

Close-up of exposed fault core material at Station PR-65. Note compass for scale.

Figure A-19

Fault Station PR-65 (part two) 


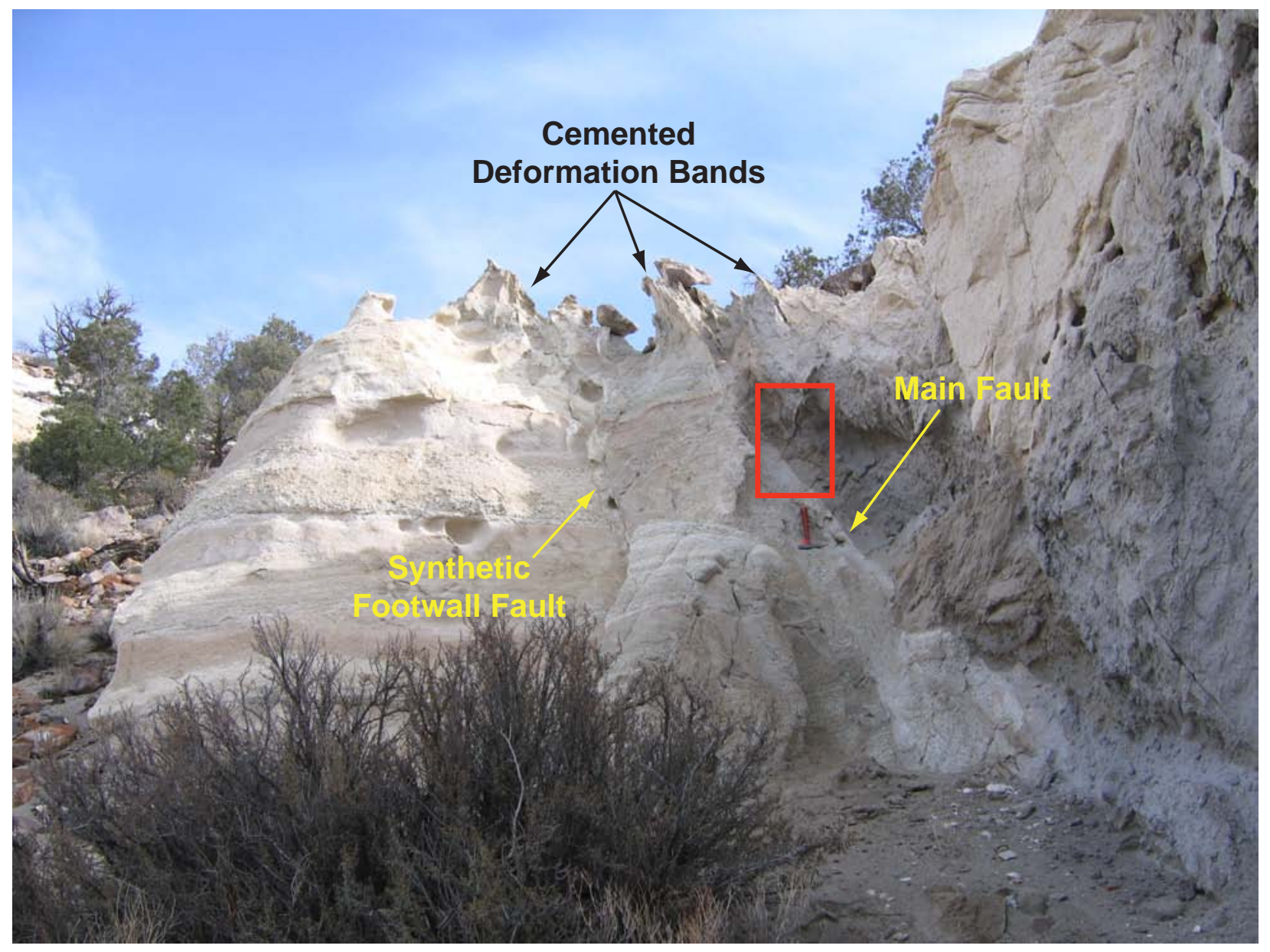

Normal fault in vitric-tuff aquifer showing damage zone features typical of weakly consolidated vitric tuff. Red square indicates location of close-up photograph at right. Note criss-crossing deformation bands (red arrows) adjacent to fault in the hanging wall. Note rock hammer (below red square) for scale in upper photograph.

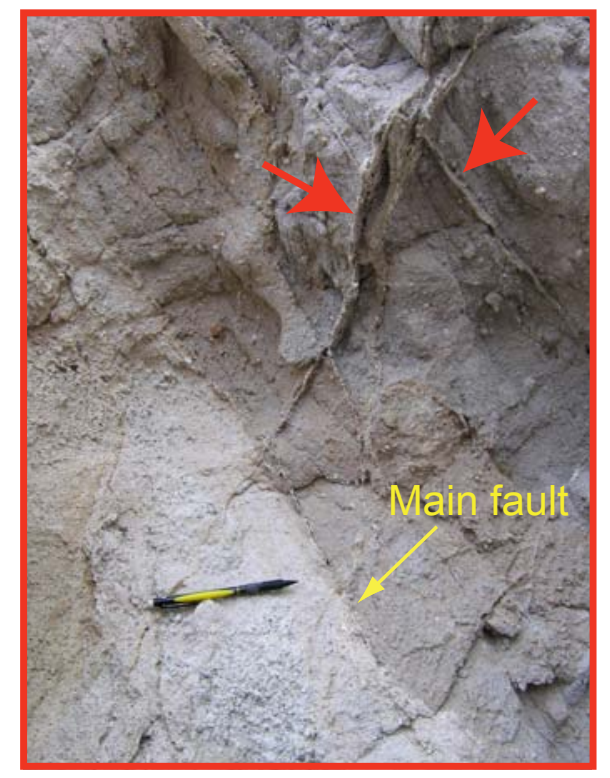

Figure A-20

Fault Station TP-100 


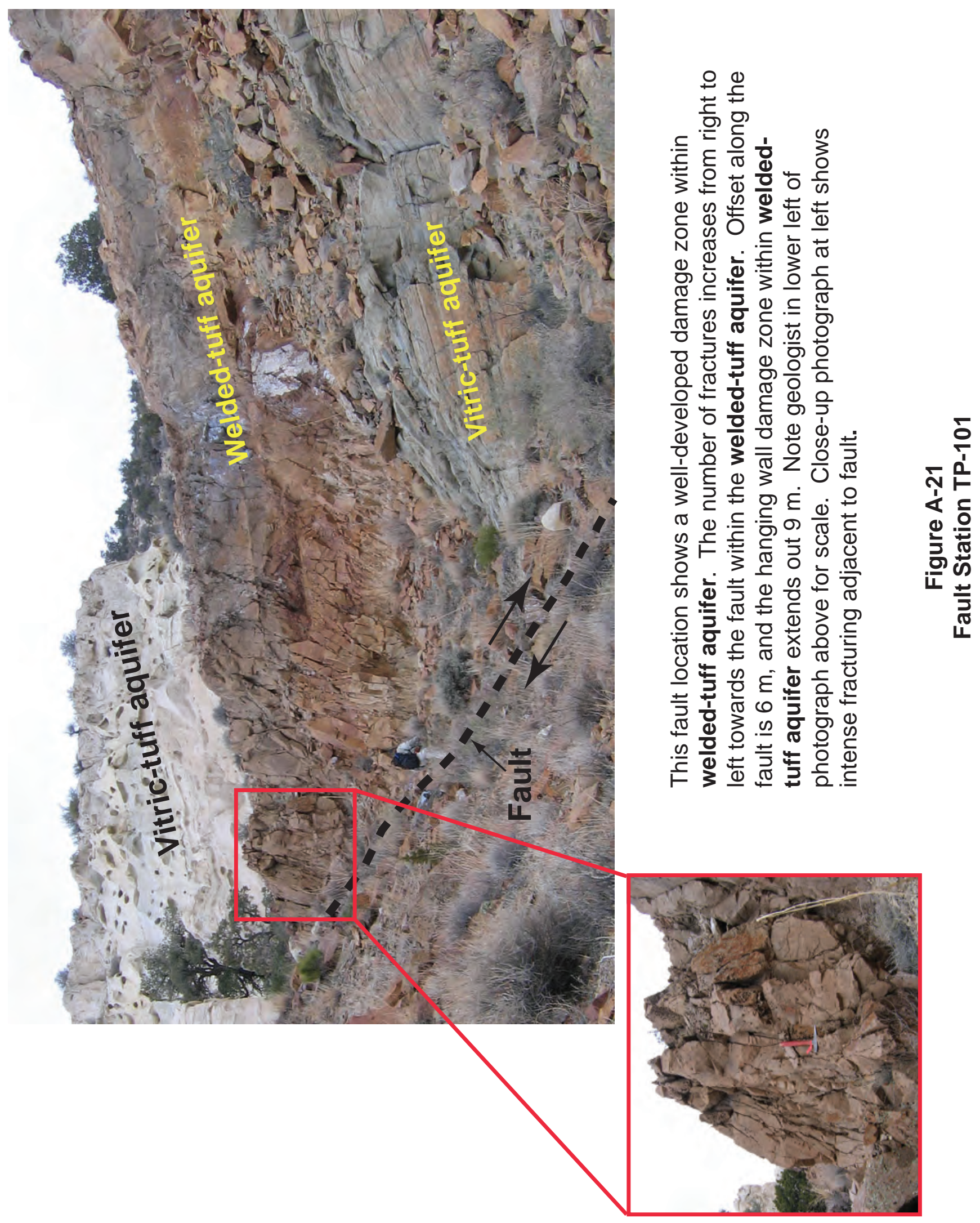




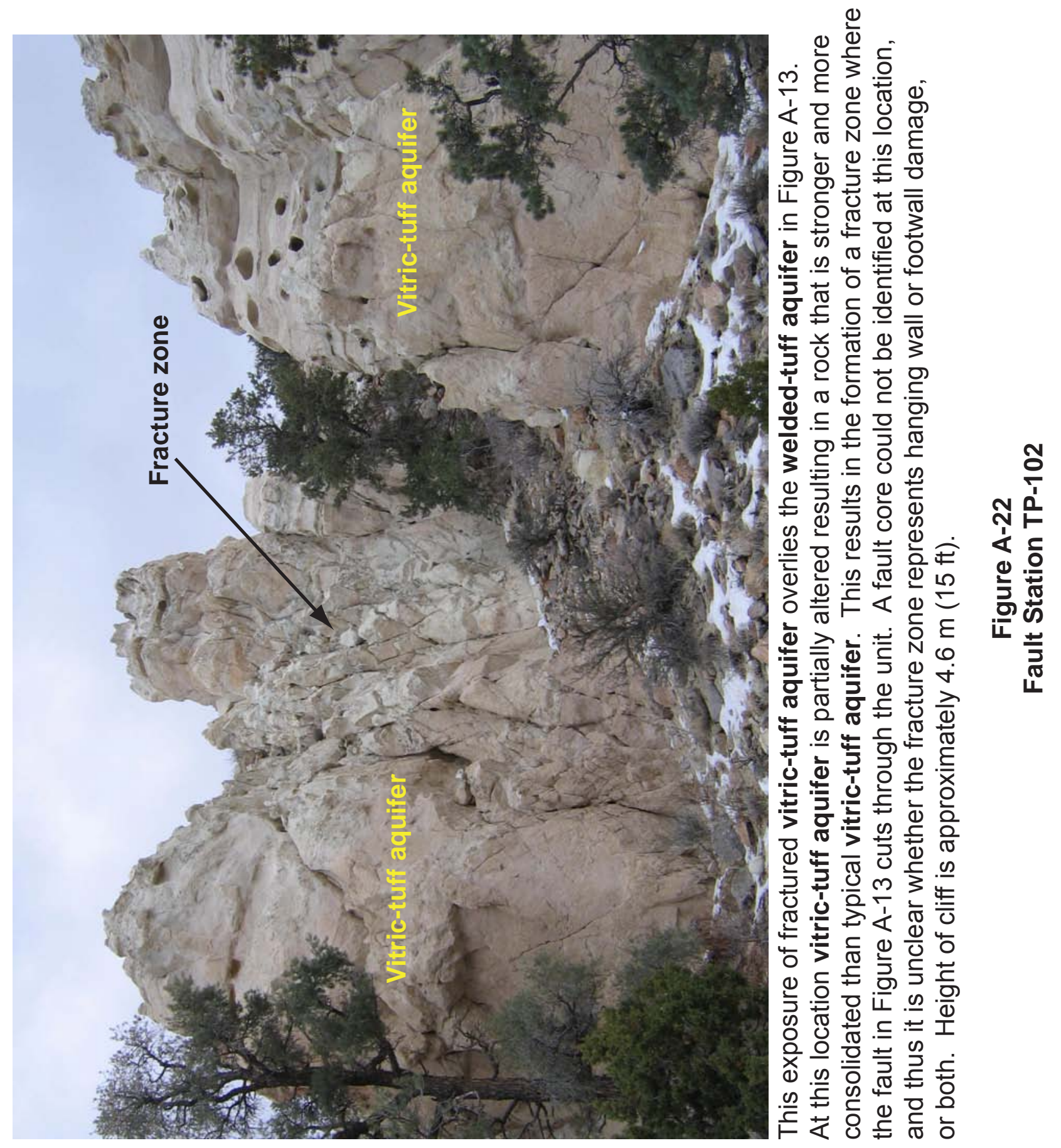




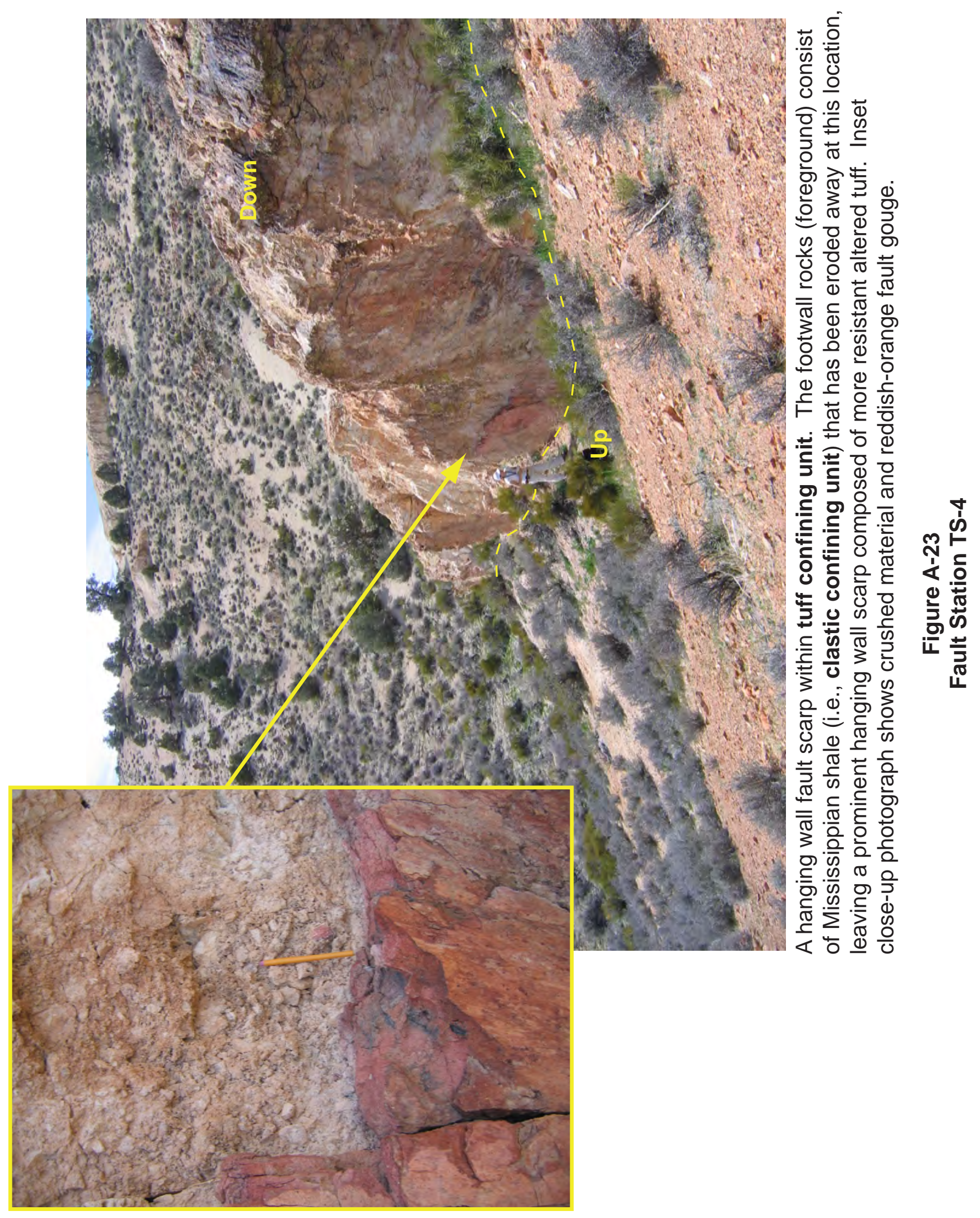



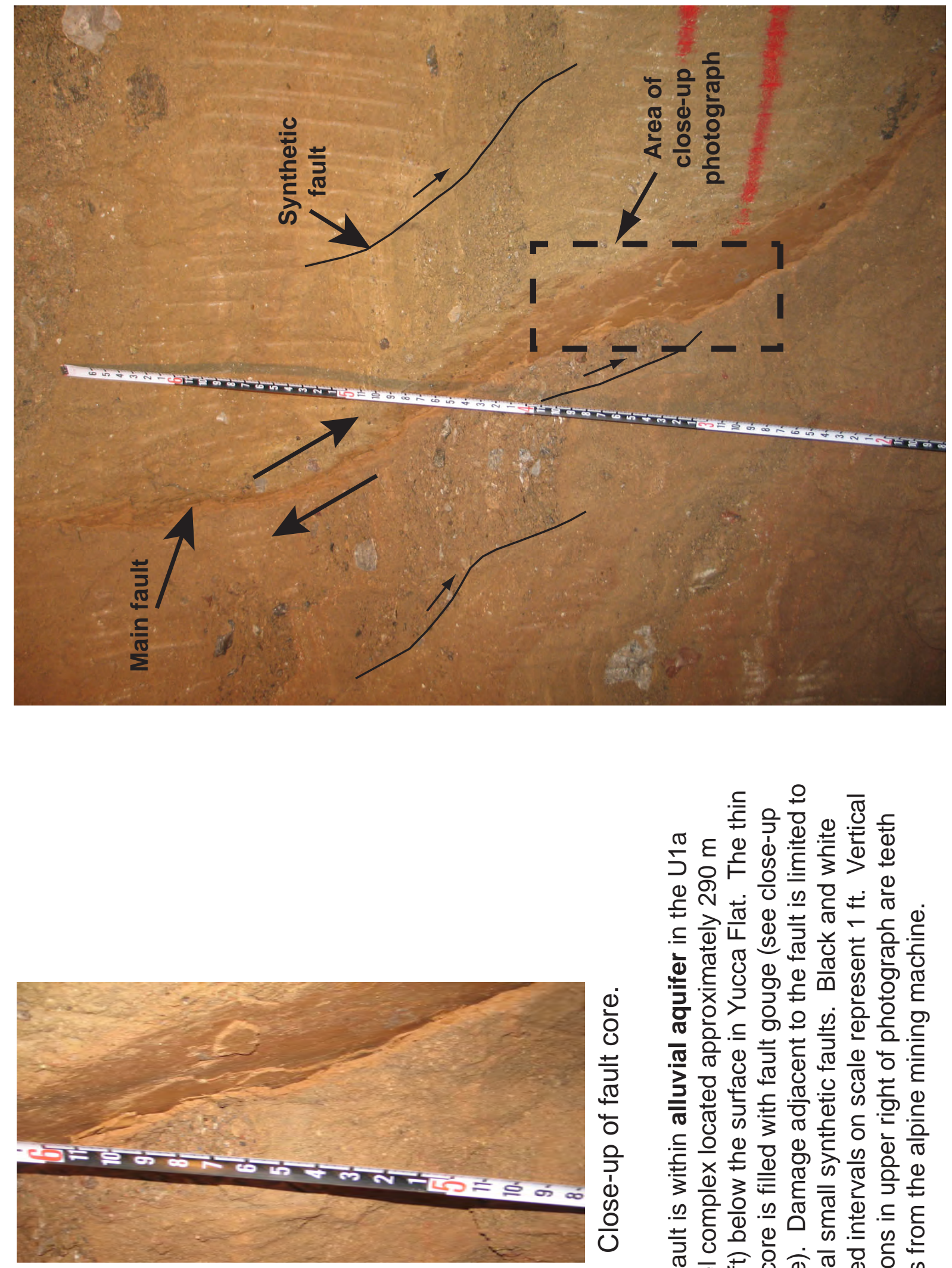

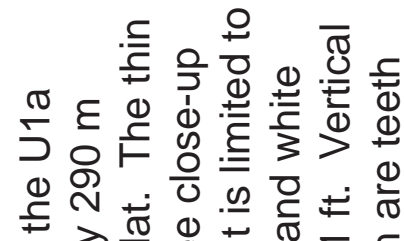

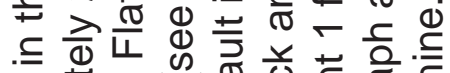
흔 屯 "亏

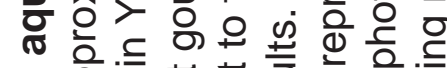

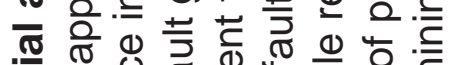
元 引 원

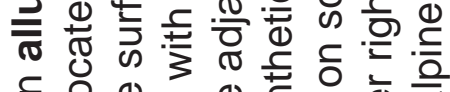

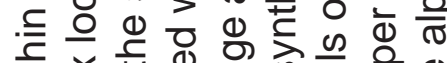

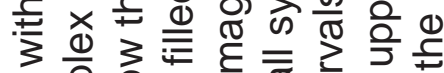

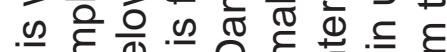
言

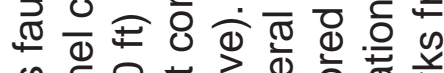

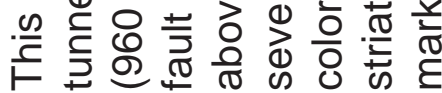




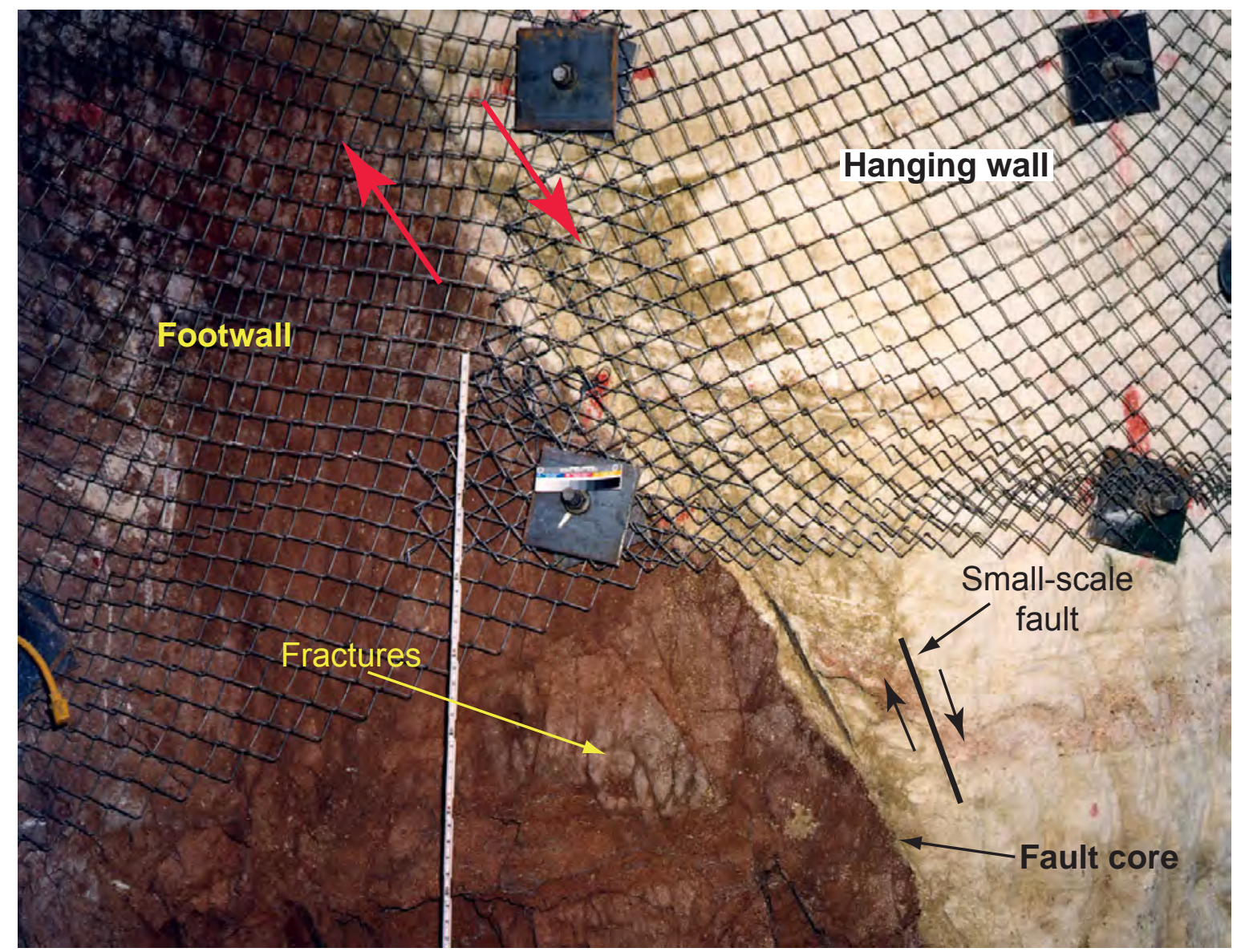

This normal fault within tuff confining unit in N-Tunnel has a very thin fault core. Damage in the footwall consists of numerous mostly tight fractures oriented subparallel to the main fault. Hanging wall damage is considerably less than in the

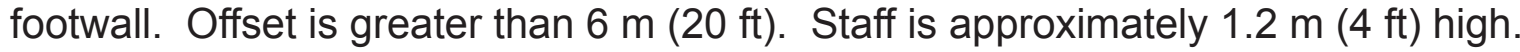

Figure A-25

Fault Station N-GSD X-Cut 


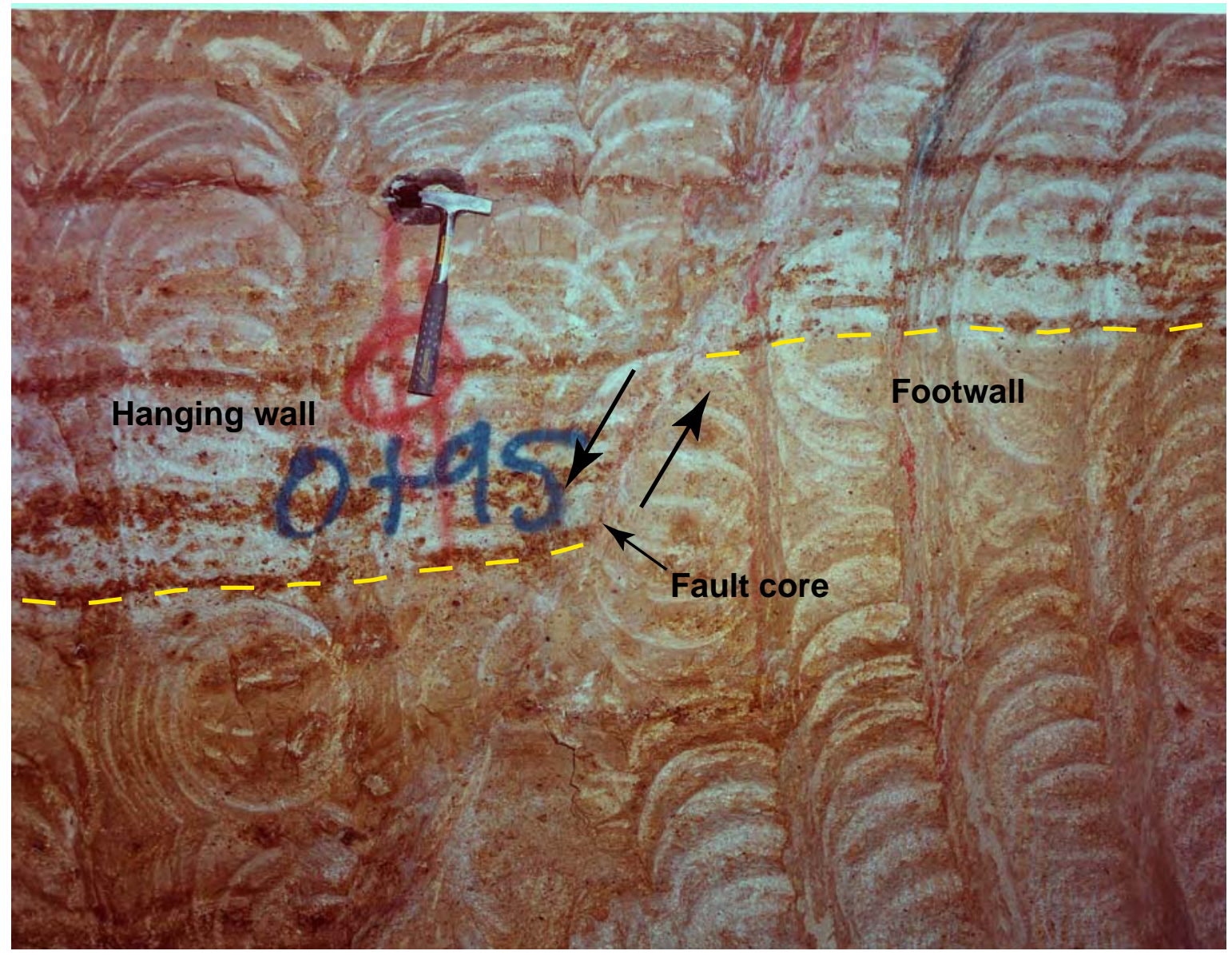

This normal fault is within tuff confining unit in N-Tunnel. The fault has a thin fault core and shows minimal damage. Circular marks were made by the mining machine. Offset is $0.4 \mathrm{~m}(1.2 \mathrm{ft})$. The hammer is 28 centimeters $(\mathrm{cm})(0.9 \mathrm{ft})$ long.

Figure A-26

Fault Station N-10-A 


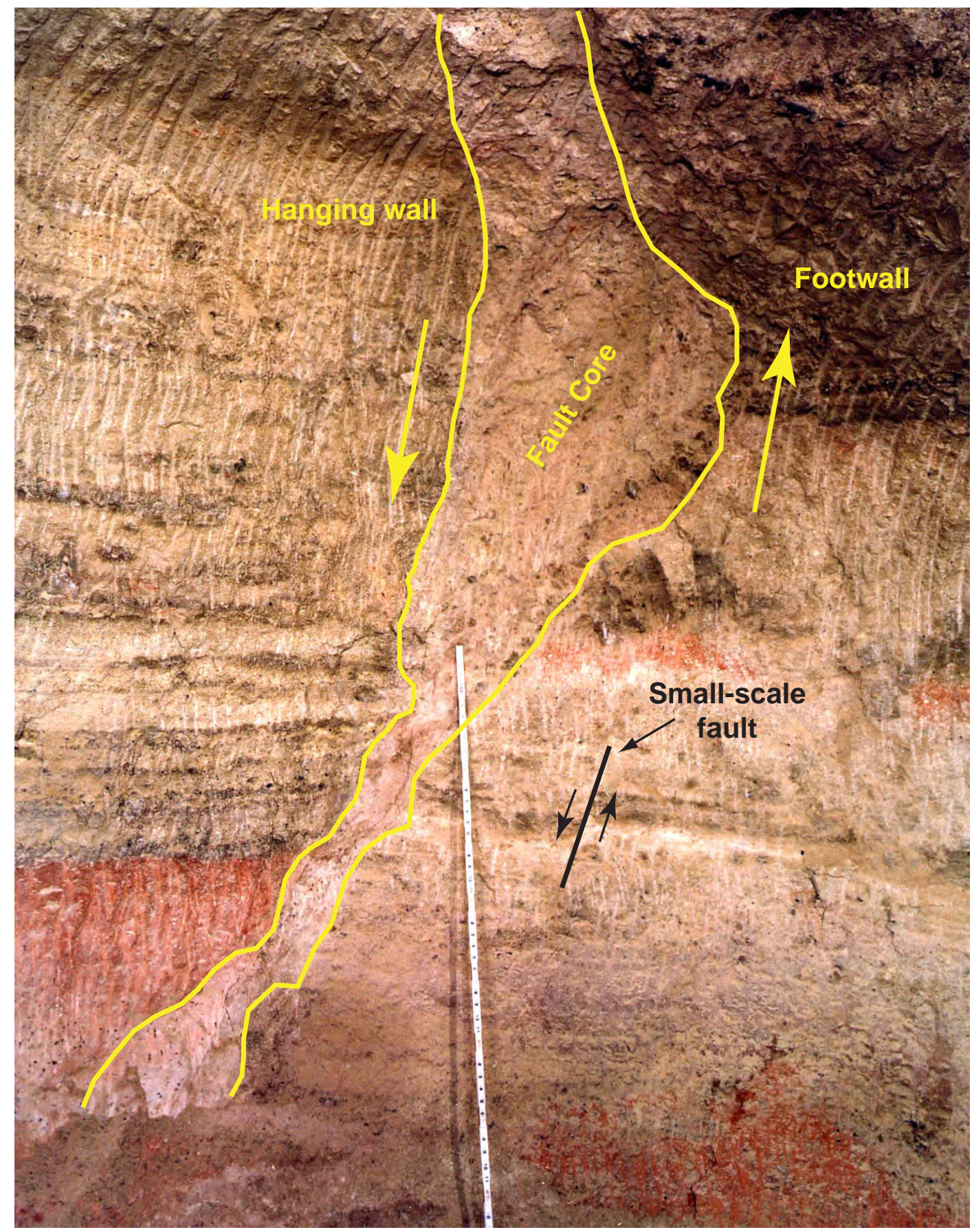

This normal fault within tuff confining unit is exposed in the wall of a drift in N-Tunnel. The drift intersected this fault at a low angle; thus, the fault plane is sub-parallel to this view and extends into the side of the drift from left to right, dipping away from the reader. Amount of offset is greater than $6 \mathrm{~m}$ (20 ft). The fault core is less than $15 \mathrm{~cm}$ (6 inches [in.]) wide and is composed of clayey fault gouge. Damage in both the footwall and hanging wall is negligible. Staff is $1.2 \mathrm{~m}(4 \mathrm{ft})$ high.

Figure A-27

Fault Station N-21BP-2 


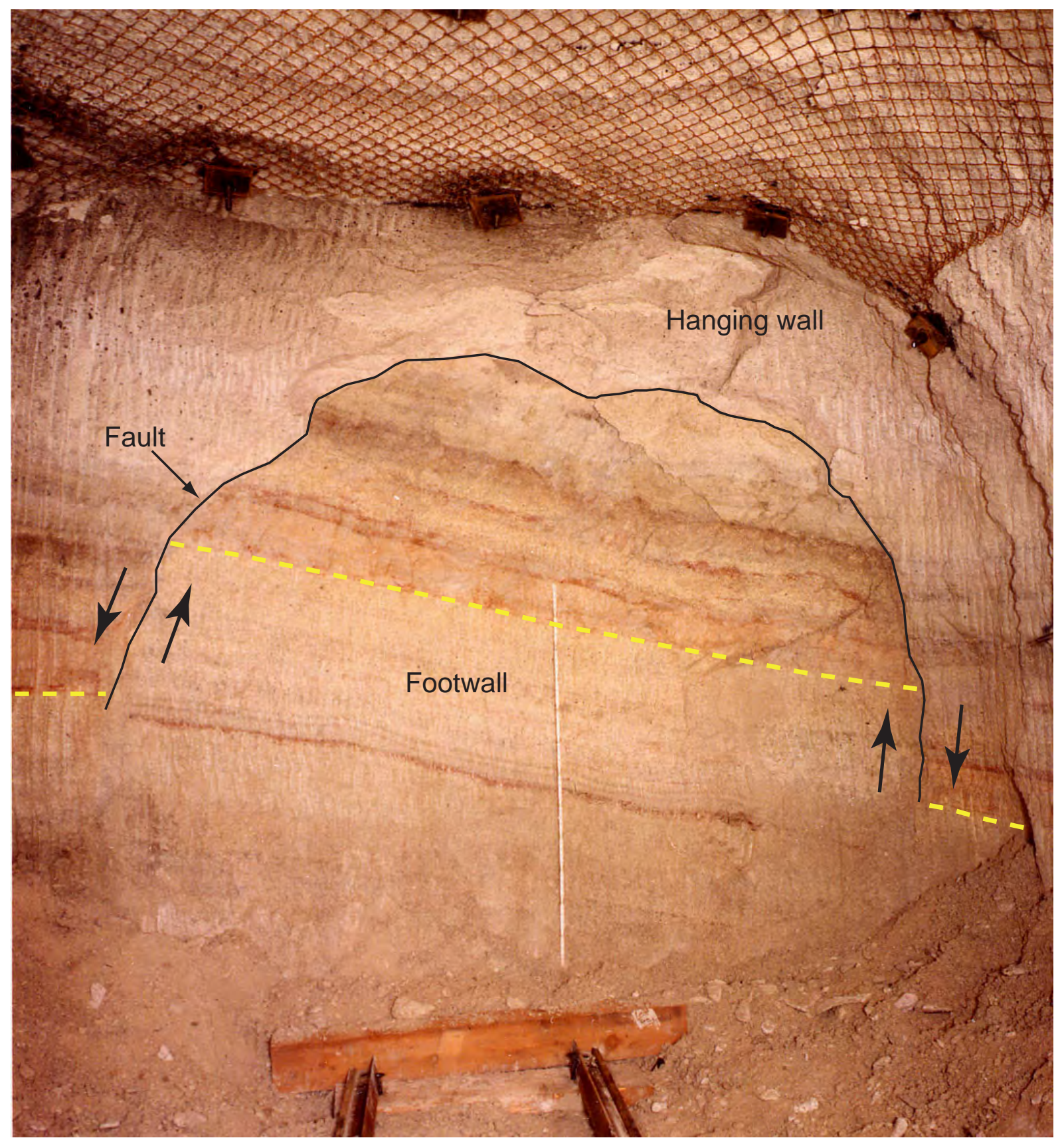

This fault exposure is at the end of a drift in N-Tunnel that has been mined perpendicular to a normal fault within tuff confining unit. The fault dips toward the reader. Offset is between 0.6 and $0.9 \mathrm{~m}(2$ and $3 \mathrm{ft})$. Note very thin fault core and lack of damage. Staff is $1.8 \mathrm{~m}(6 \mathrm{ft})$ high.

Figure A-28

Fault Station N-17BP 


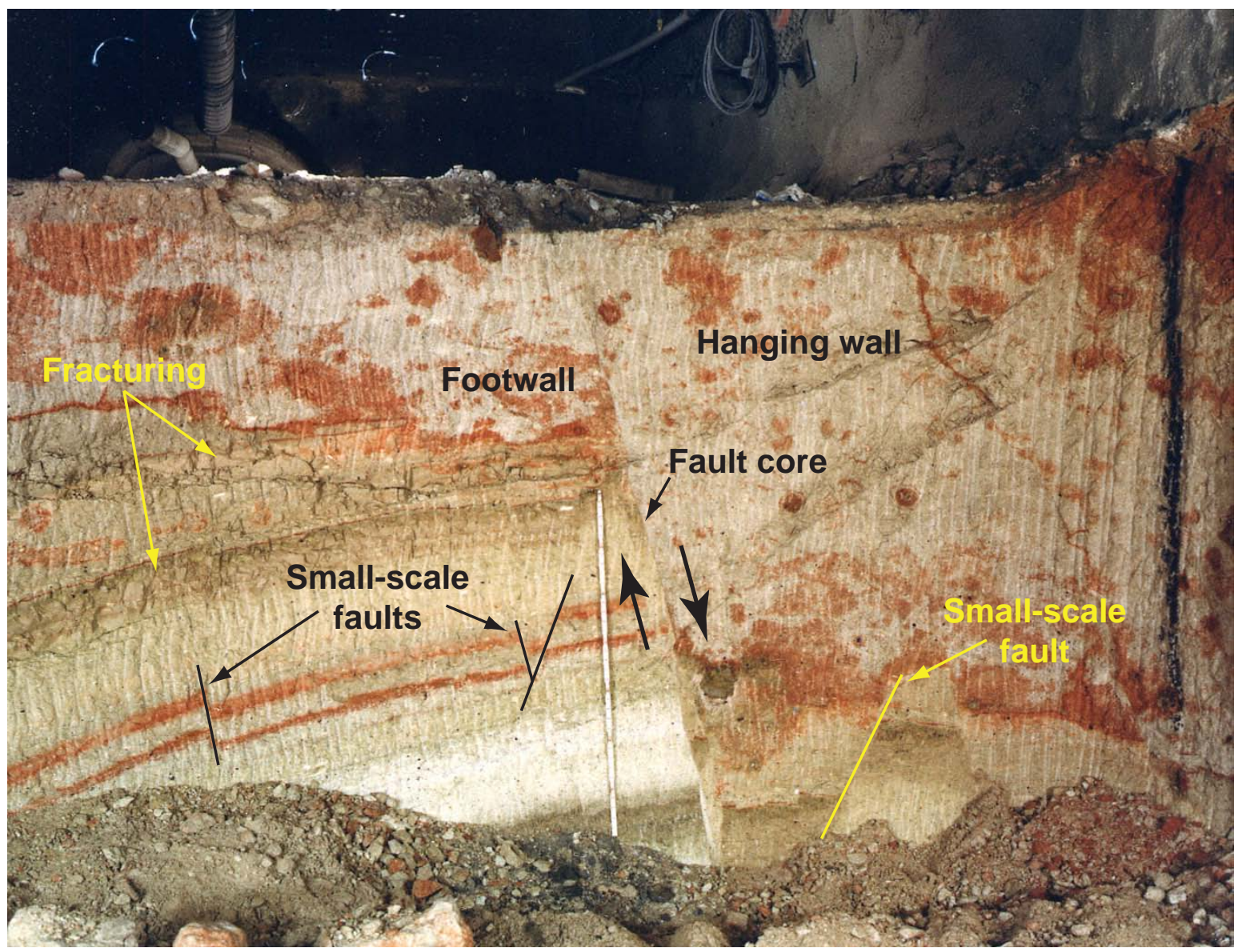

This normal fault within tuff confining unit in N-Tunnel shows minor damage consisting of fracturing and small-scale faulting. Fracturing is most pronounced in silicified beds in the footwall. The fault core is very narrow, generally less than

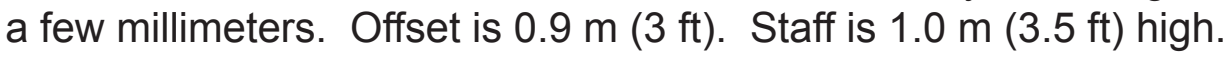

Figure A-29

Fault Station N-21LOS-1 


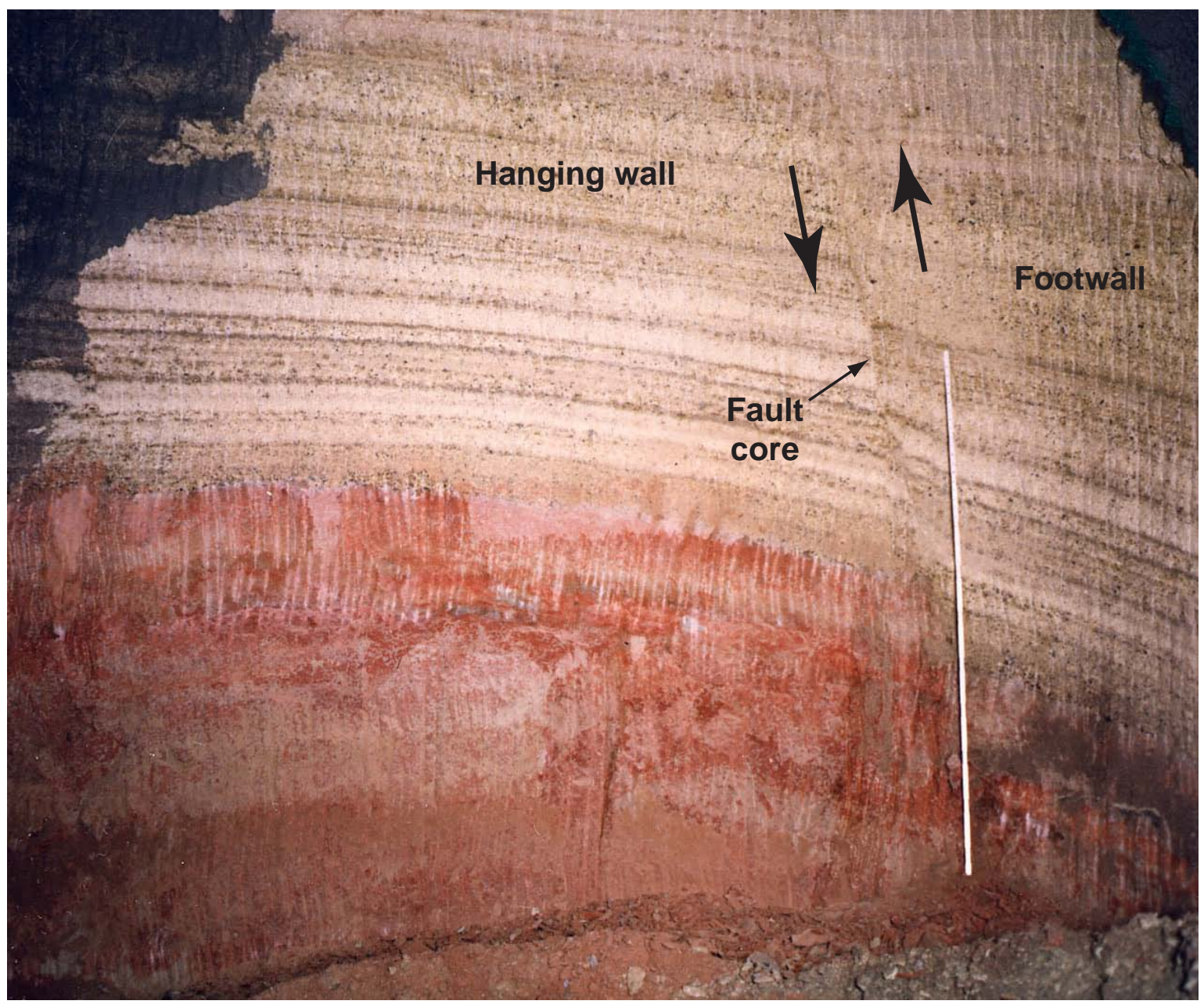

This normal fault within tuff confining unit in N-Tunnel shows no fault-related damage. The width of the fault core is less than $1 \mathrm{~cm}(0.4 \mathrm{in})$. Offset is $0.3 \mathrm{~m}(1 \mathrm{ft})$. Staff is $1.8 \mathrm{~m}(6 \mathrm{ft})$ high. 


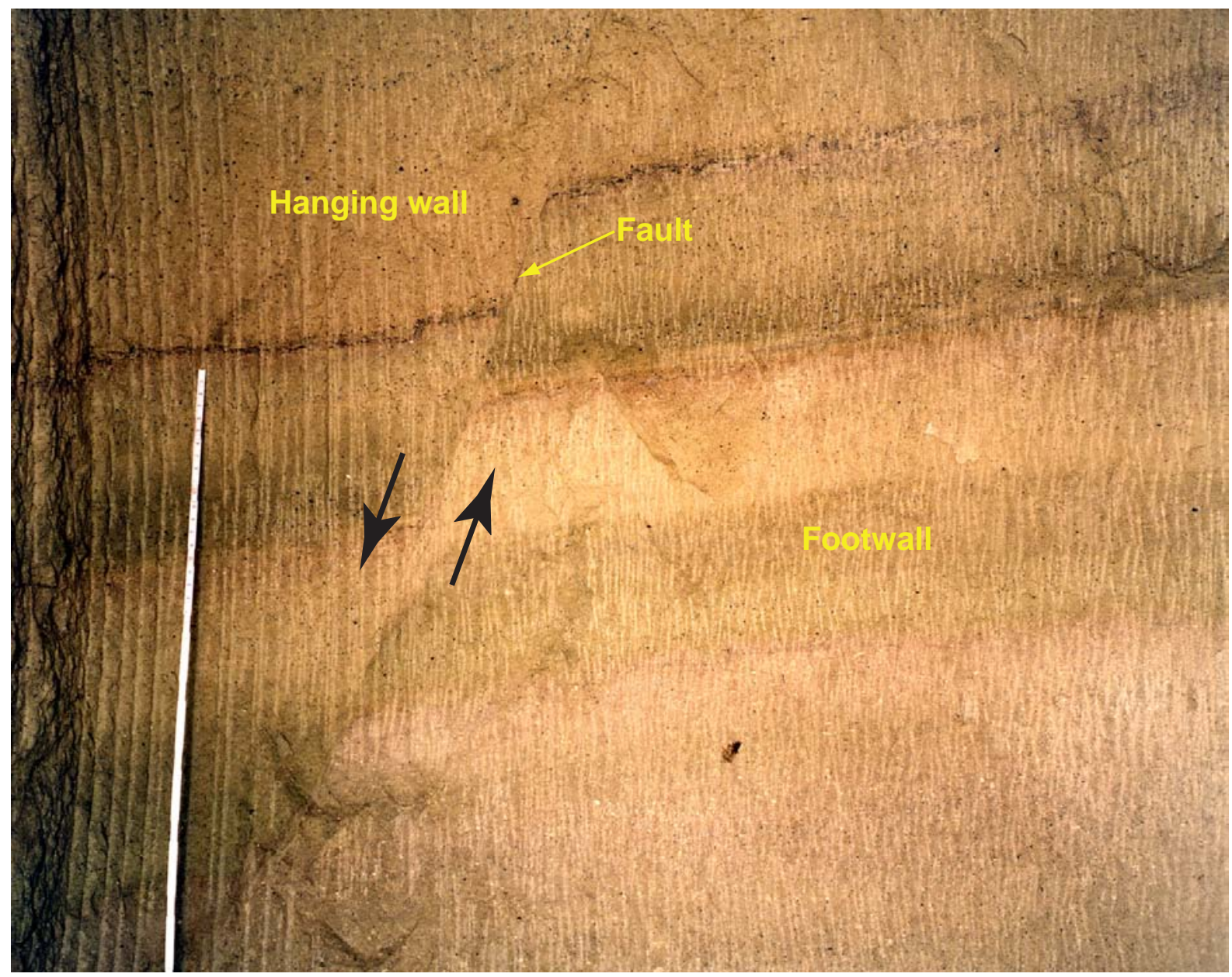

This small normal fault within tuff confining unit in $\mathrm{N}$-Tunnel shows no fault-related damage. The fault core is less than $1 \mathrm{~cm}(0.4 \mathrm{in}$.) wide. Offset is $0.2 \mathrm{~m}(0.7 \mathrm{ft})$. Staff is $1.4 \mathrm{~m}(4.5 \mathrm{ft})$ high.

Figure A-31

Fault Station N-22BP 


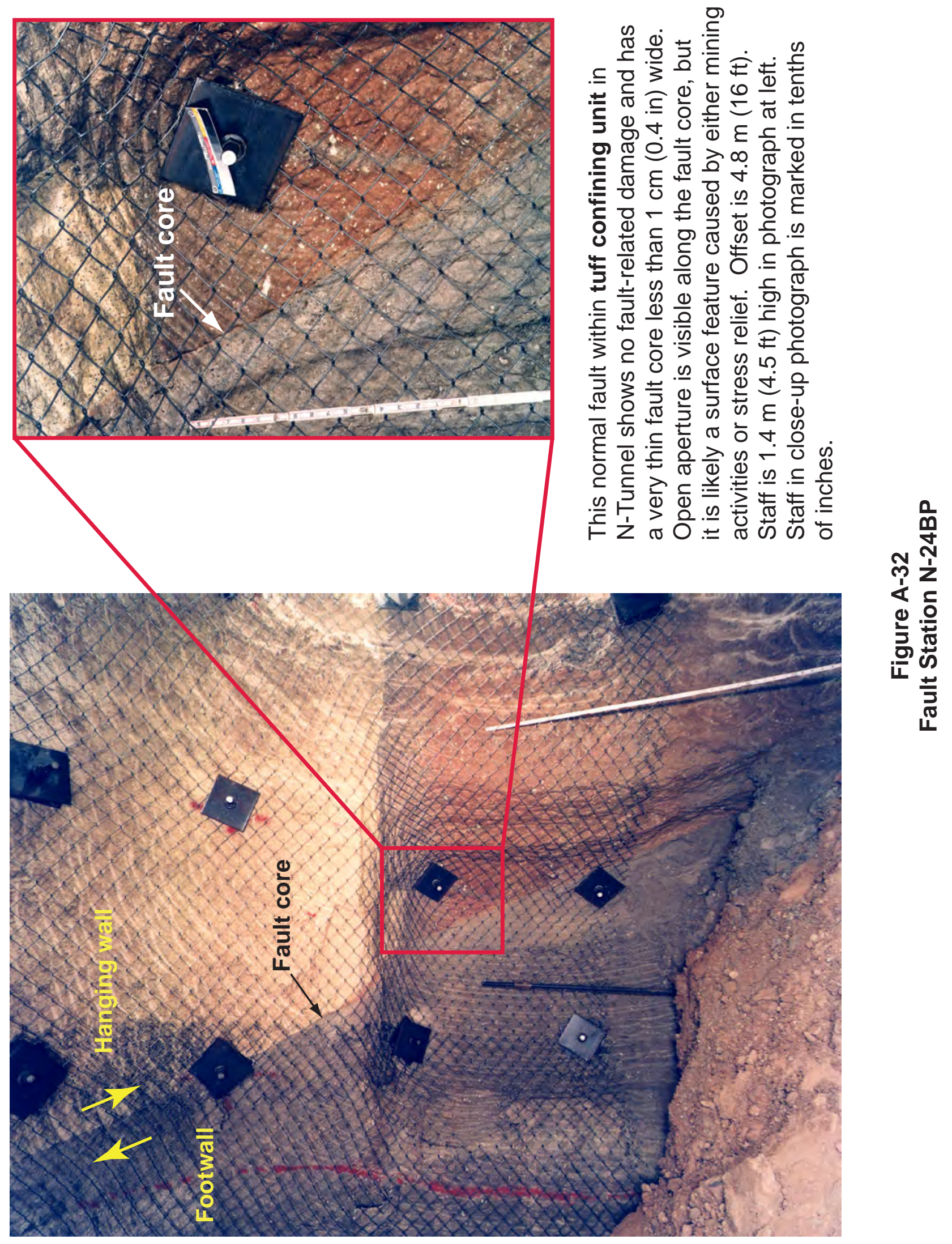




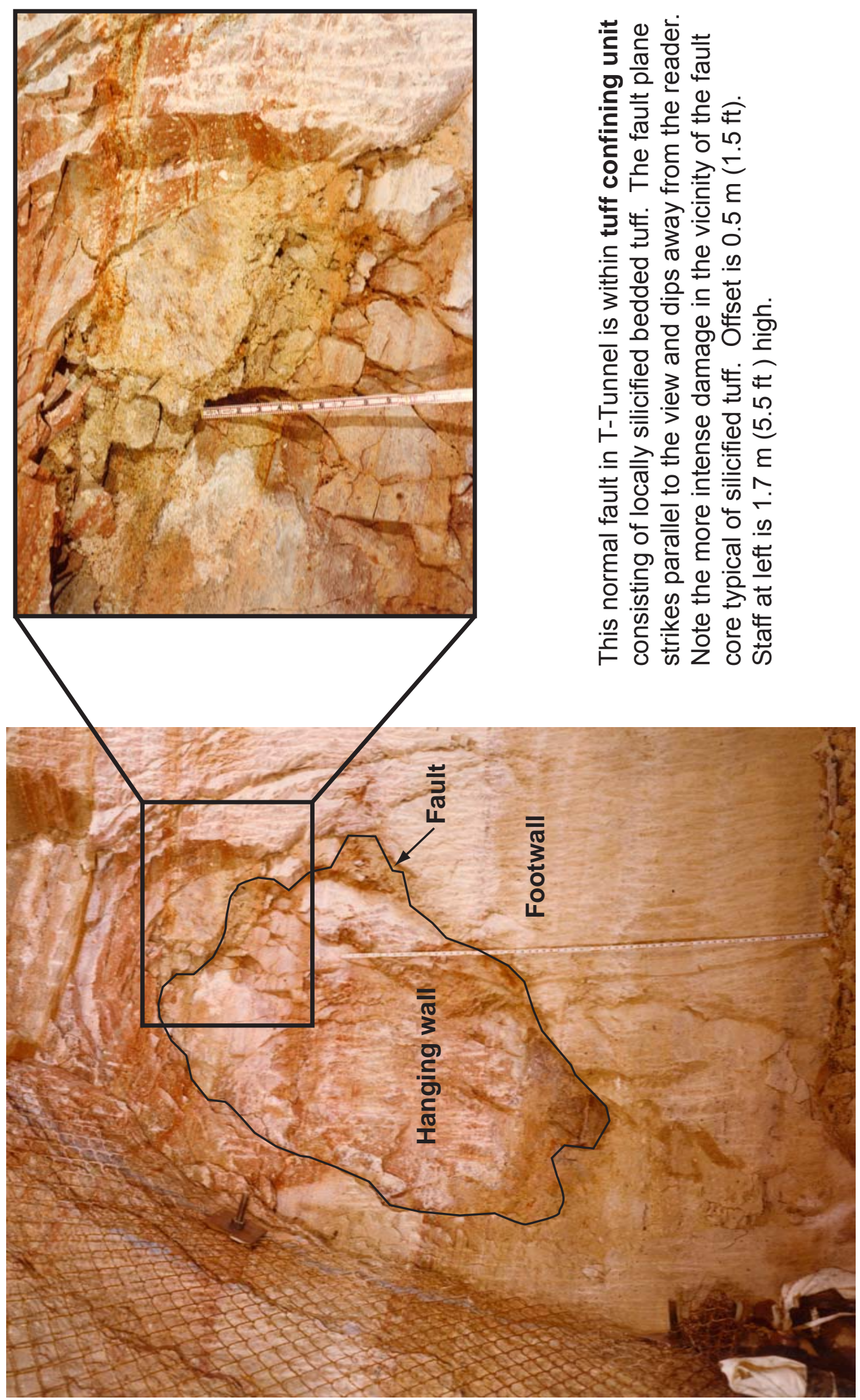

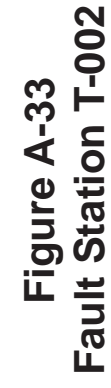




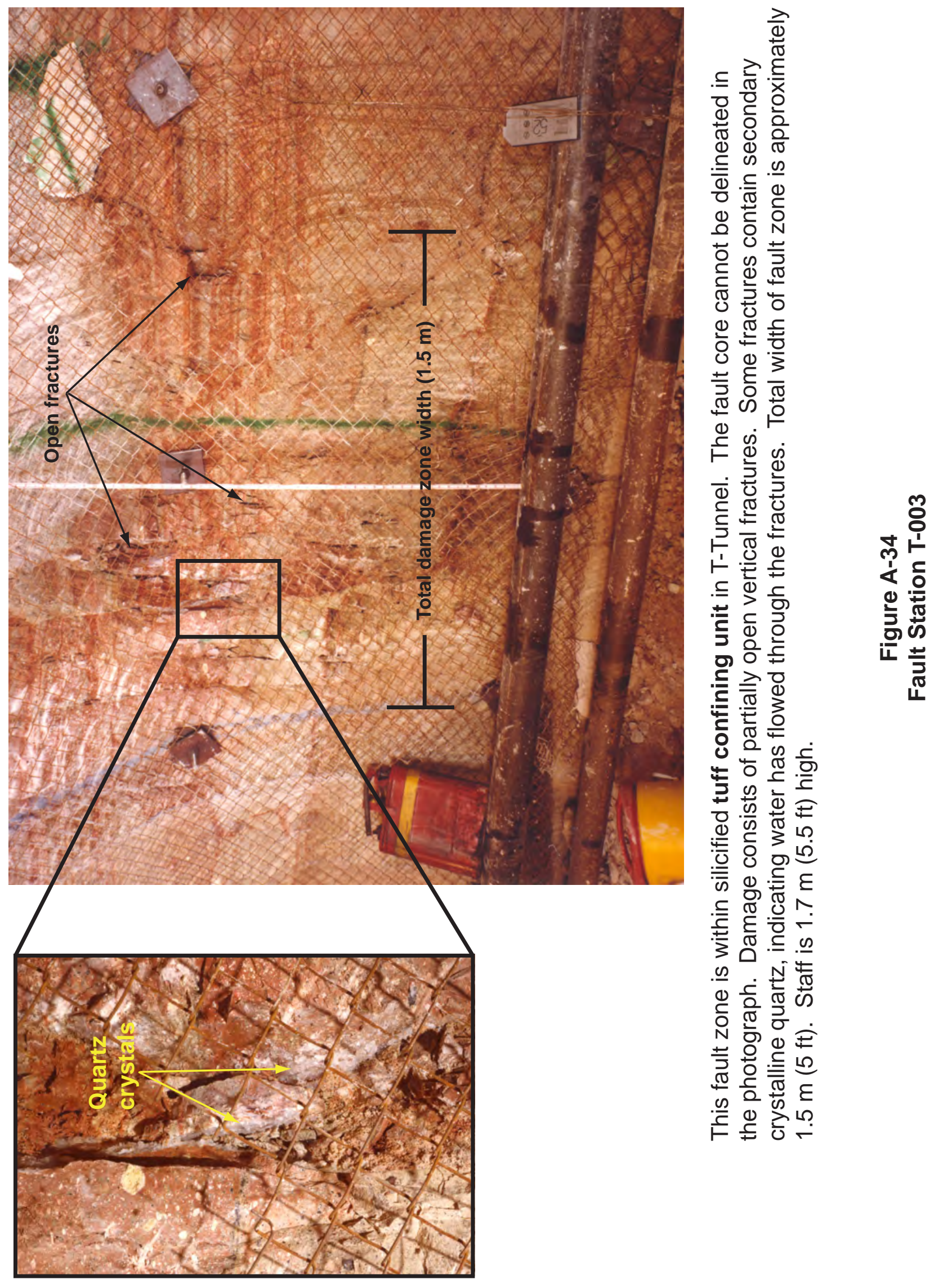



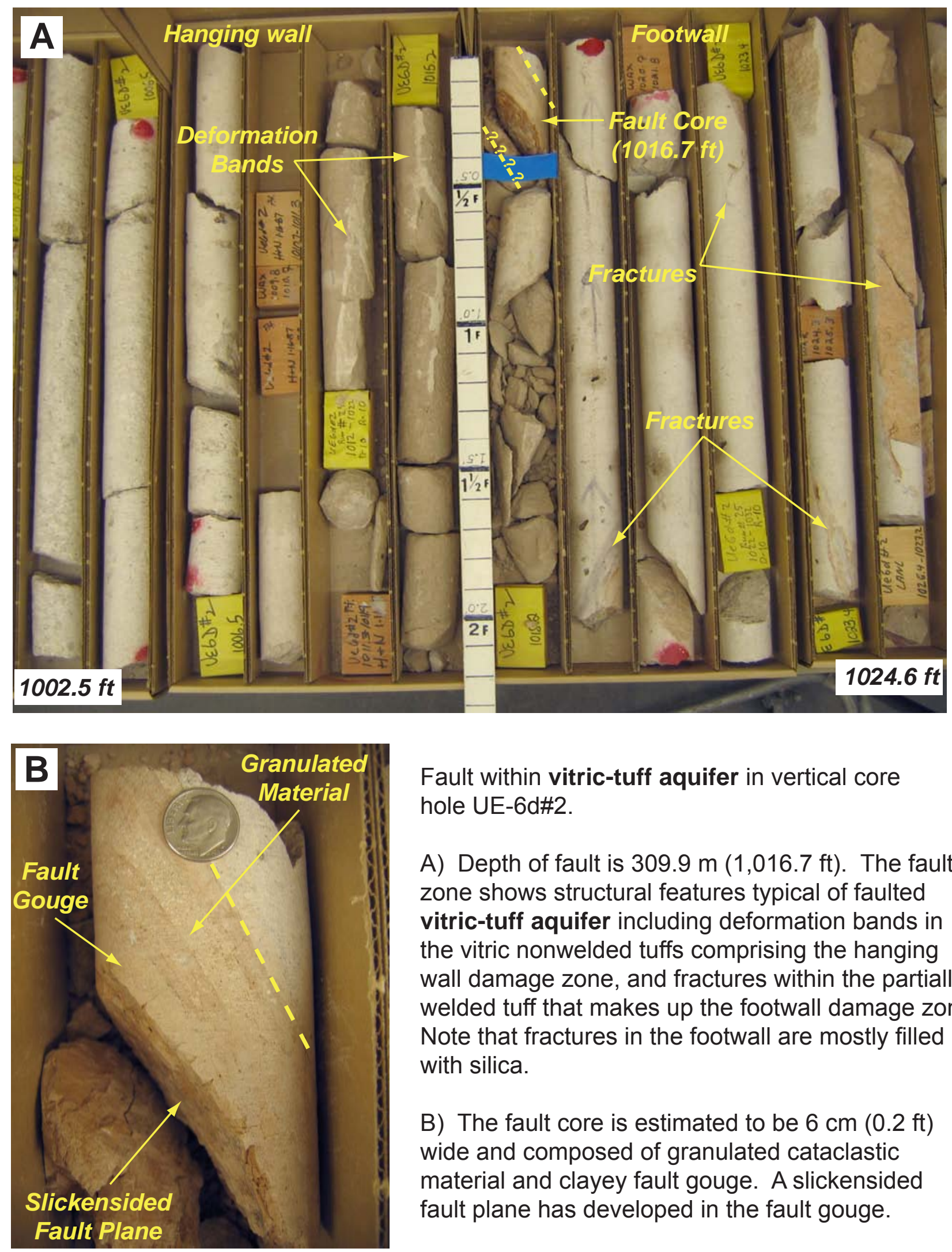

Fault within vitric-tuff aquifer in vertical core hole UE-6d\#2.

A) Depth of fault is $309.9 \mathrm{~m}(1,016.7 \mathrm{ft})$. The fault zone shows structural features typical of faulted vitric-tuff aquifer including deformation bands in the vitric nonwelded tuffs comprising the hanging wall damage zone, and fractures within the partially welded tuff that makes up the footwall damage zone. Note that fractures in the footwall are mostly filled with silica.

B) The fault core is estimated to be $6 \mathrm{~cm}(0.2 \mathrm{ft})$ wide and composed of granulated cataclastic material and clayey fault gouge. A slickensided fault plane has developed in the fault gouge.

Figure A-35

Fault Station UE-6d\#2-1016.7 


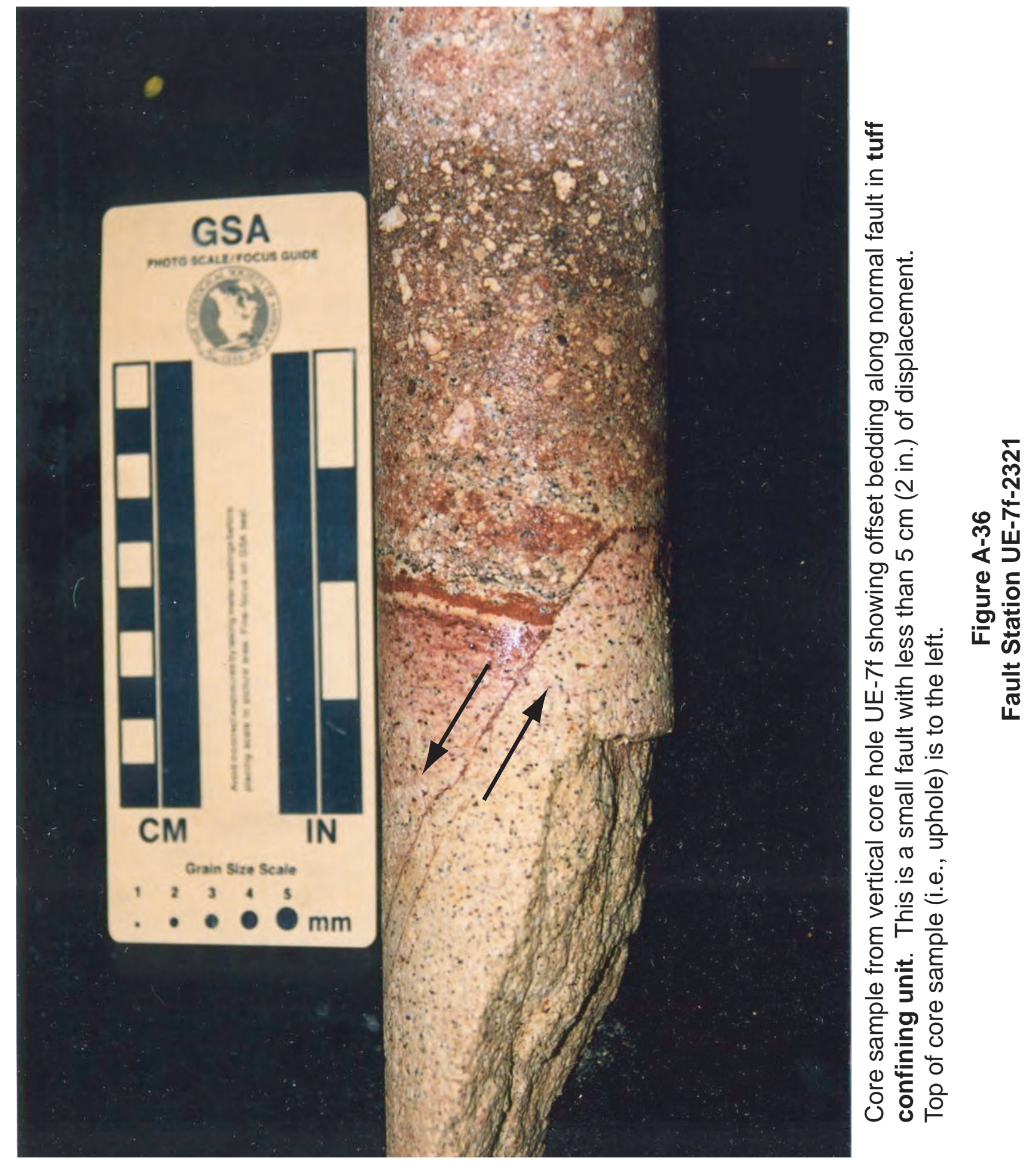




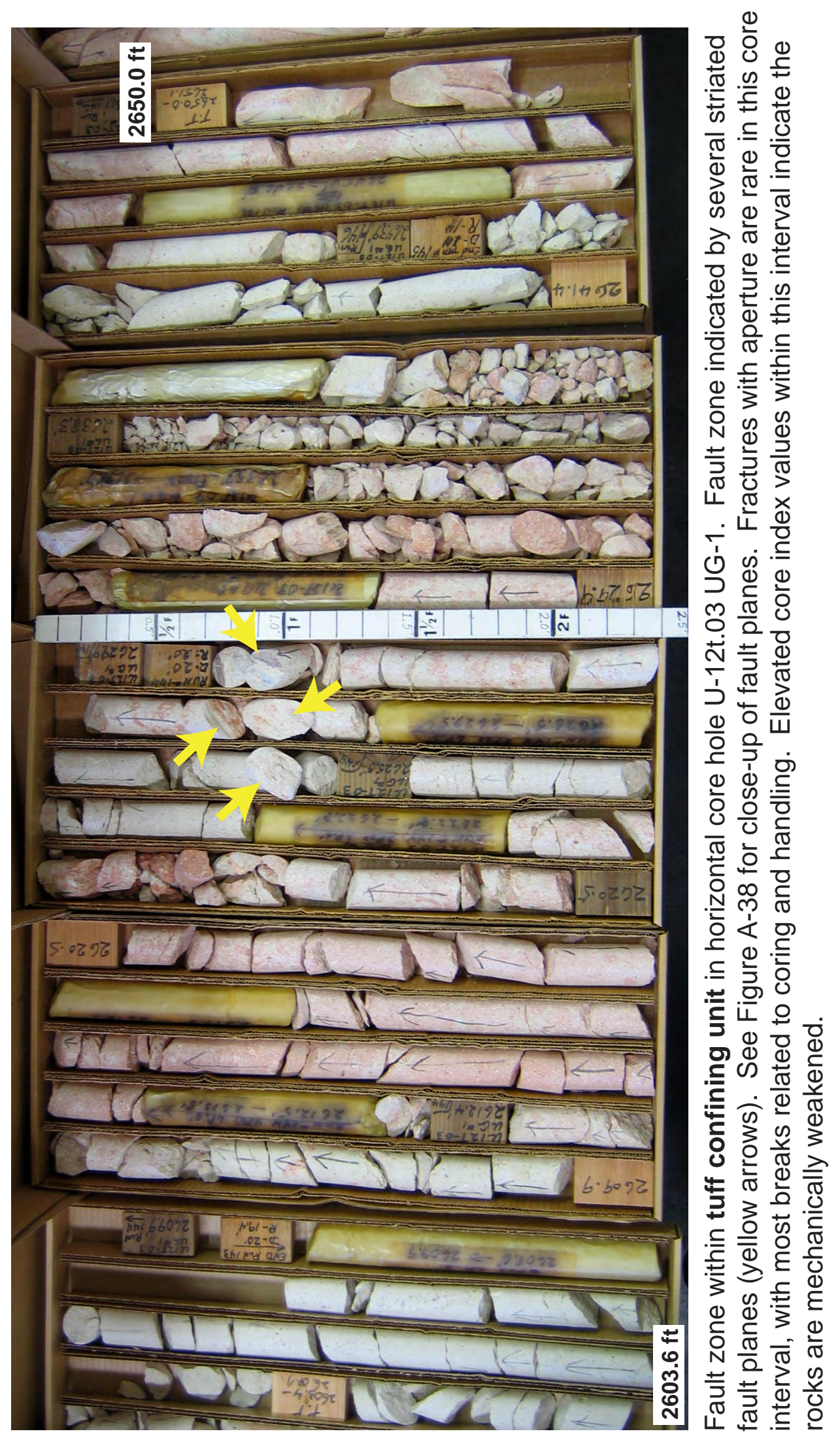

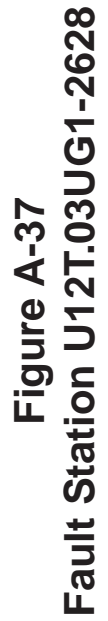




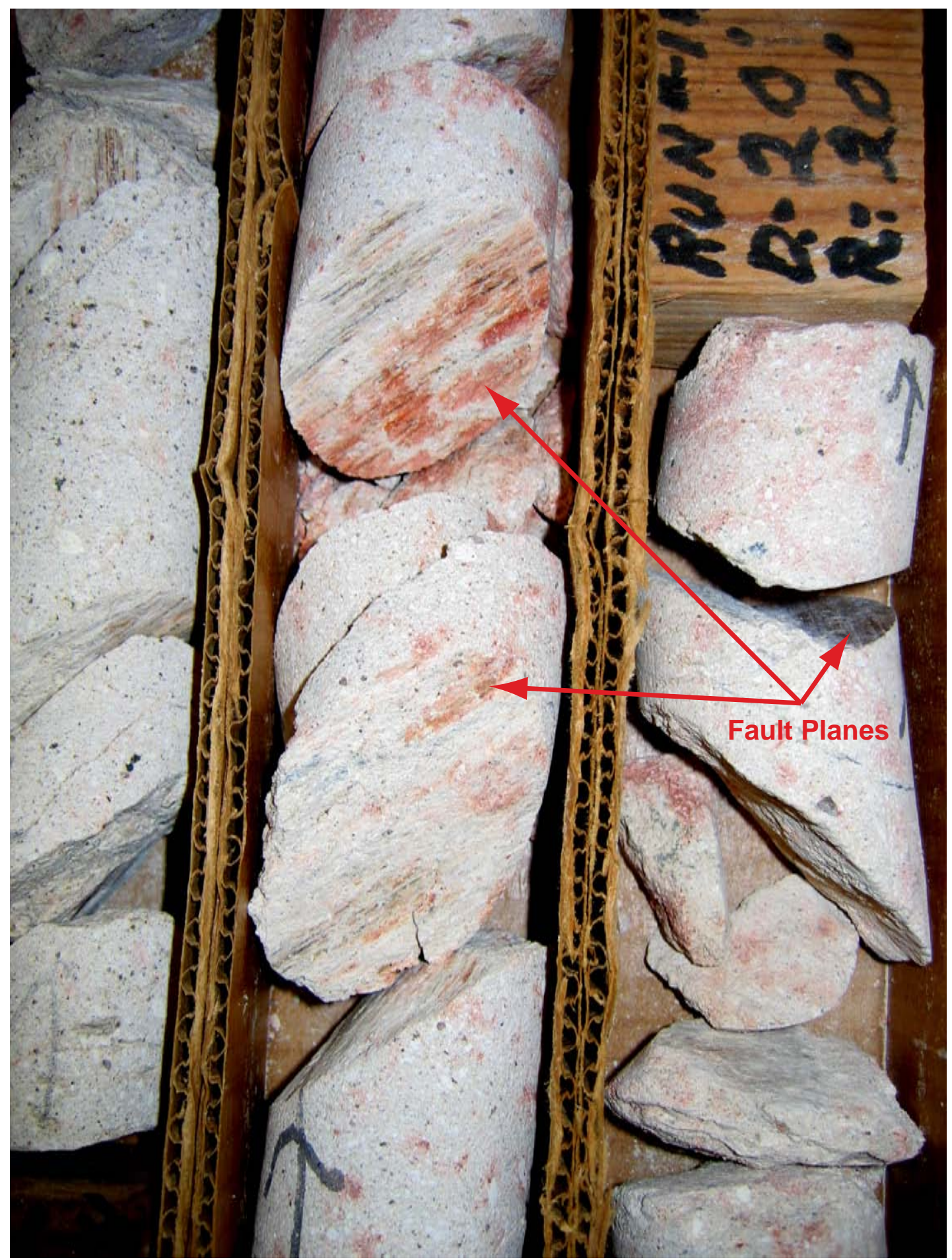

Close-up of fault planes within tuff confining unit in horizontal core hole $\mathrm{U}-12 \mathrm{t} .03 \mathrm{UG}-1$. Core is $5.1 \mathrm{~cm}(2 \mathrm{in}$.) in diameter. 


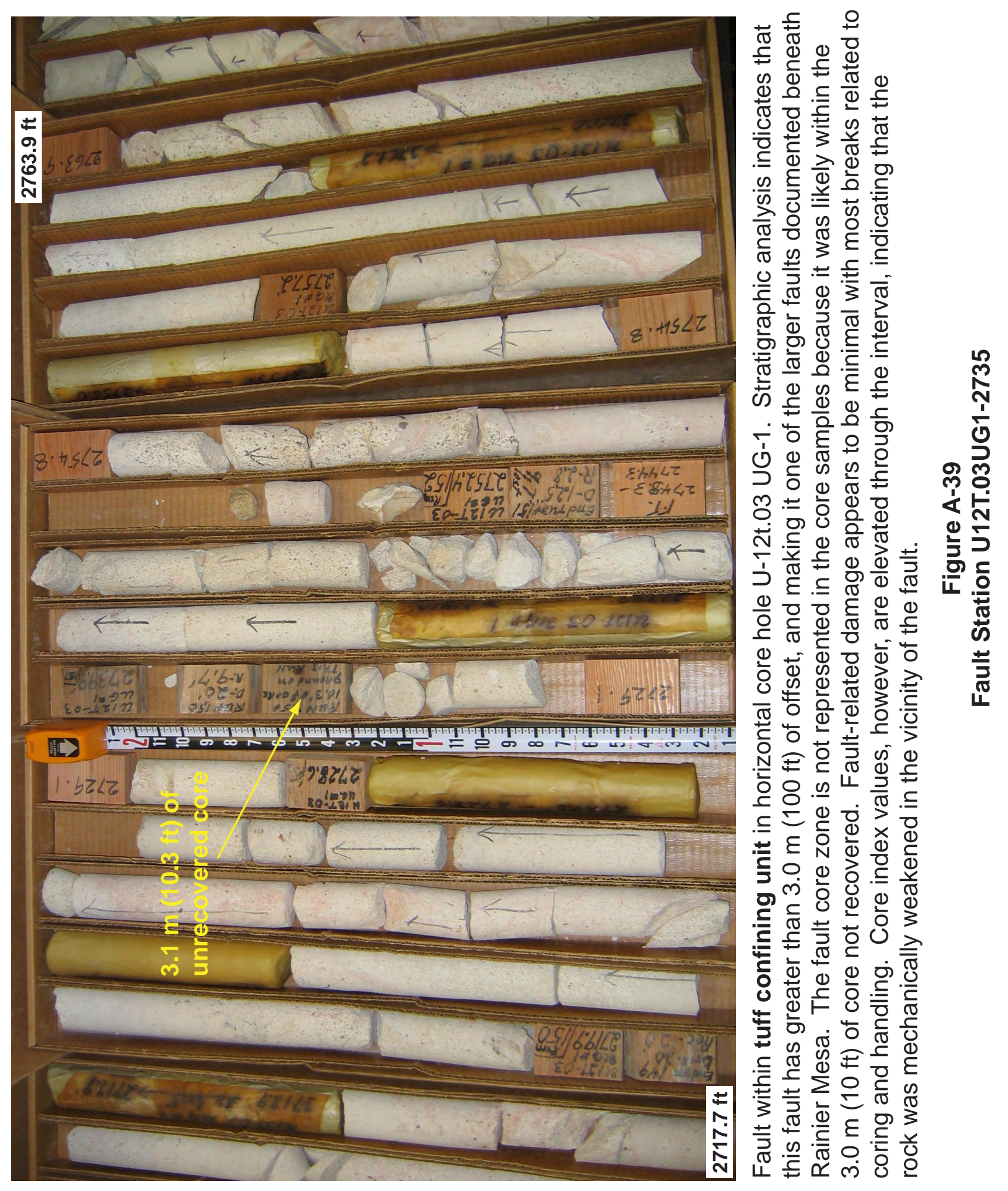



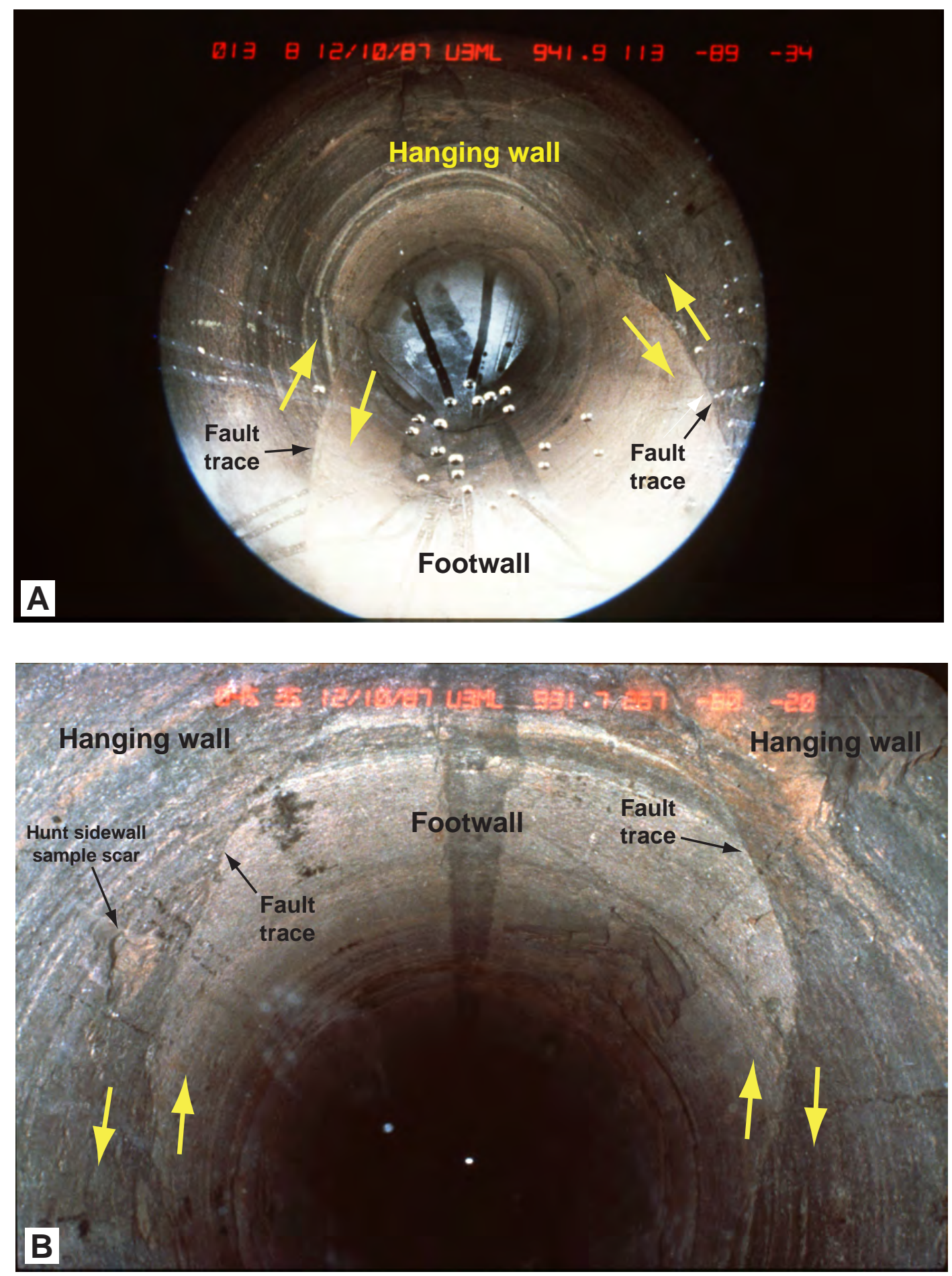

Down-hole camera views of fault within tuff confining unit in emplacement

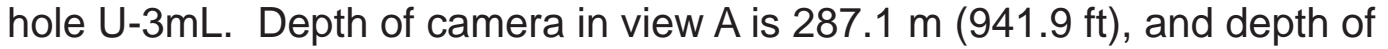
camera in view $B$ is $284.0 \mathrm{~m}(931.7 \mathrm{ft})$. Offset along fault is approximately $1.8 \mathrm{~m}(6 \mathrm{ft})$. Hole diameter is $2.4 \mathrm{~m}(8 \mathrm{ft})$. Note very thin fault core and lack of noticable damage in both the footwall and hanging wall.

Figure A-40

Fault Station U-3mL-2940 


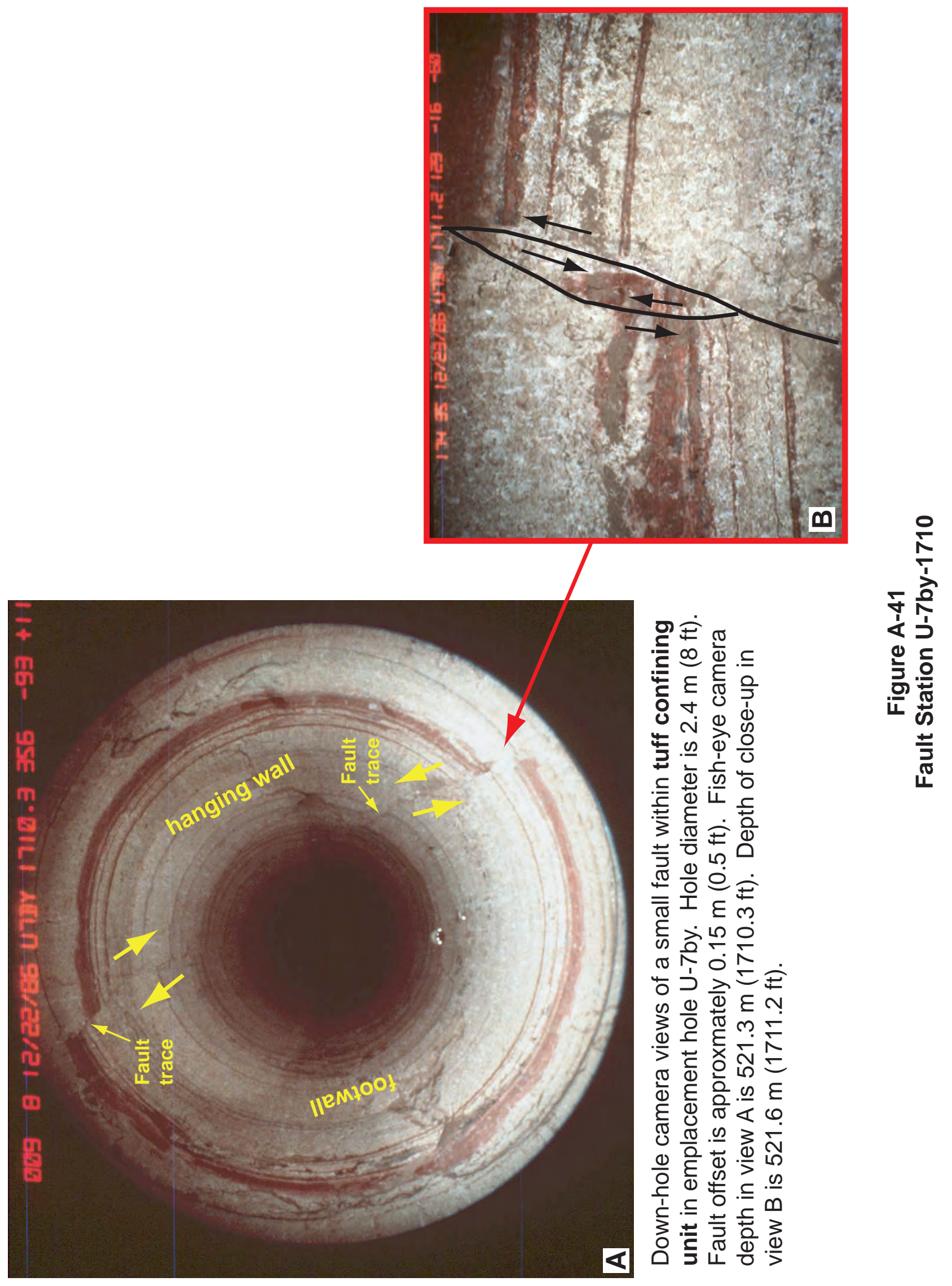


This page intentionally left blank. 